\title{
Role of Traditional Chinese Medicine in the Management of Viral Pneumonia
}

\author{
Shengyan Xi ${ }^{1,2 *}$, Yunhong $\mathrm{Li}^{1 \dagger}$, Lifeng Yue ${ }^{3 t}$, Yuewen Gong ${ }^{4}$, Linchao Qian ${ }^{1,2,5}$, \\ Tengxiao Liang $^{3}$ and Yong'an $\mathrm{Ye}^{3 *}$
}

${ }^{1}$ Department of Traditional Chinese Medicine, School of Medicine, Xiamen University, Xiamen, China, ${ }^{2}$ Department of Traditional Chinese Medicine, Xiang'an Hospital of Xiamen University, Xiamen, China, ${ }^{3}$ The 3rd Neurology Department, Emergency Department, Gastroenterology Department, Dongzhimen Hospital, Beijing University of Chinese Medicine, Beijing, China, ${ }^{4}$ College of Pharmacy, Rady Faculty of Health Sciences, University of Manitoba, Winnipeg, MB, Canada, ${ }^{5}$ School of Traditional Chinese Medicine, Xiamen University Malaysia, Sepang, Malaysia

\section{OPEN ACCESS}

Edited by:

Michael Heinrich,

UCL School of Pharmacy,

United Kingdom

Reviewed by:

WenWu Li,

Keele University, United Kingdom Andre Luis Dias Araujo Mazzari,

University College Cork, Ireland

Colin William Wright.

University of Bradford,

United Kingdom

*Correspondence:

Shengyan $X$

xishengyan@xmu.edu.cn

Yong'an Ye

yeyongan@vip.163.com

${ }^{t}$ These authors have contributed equally to this work

Specialty section:

This article was submitted to

Ethnopharmacology,

a section of the journal

Frontiers in Pharmacology

Received: 11 July 2020

Accepted: 15 September 2020

Published: 22 October 2020

Citation:

Xi S, Li Y, Yue L, Gong Y, Qian L, Liang $T$ and Ye Y'a (2020) Role of Traditional Chinese Medicine in the Management of Viral Pneumonia.

Front. Pharmacol. 11:582322. doi: 10.3389/fphar.2020.582322
Viral pneumonia is one kind of acute respiratory tract infection caused by the virus. There have been many outbreaks of viral pneumonia with high contagiousness and mortality both in China and abroad, such as the great influenza in 1918, the severe acute respiratory syndrome (SARS) coronavirus in 2003, the Influenza A (H1N1) virus in 2009, and the Middle East Respiratory Syndrome coronavirus (MERS-CoV) in 2012 and the severe acute respiratory syndrome coronavirus 2 (SARS-CoV-2) in 2019. These outbreaks and/ or pandemic have significant impact on human life, social behaviors, and economic development. Moreover, no specific drug has been developed for these viruses. Traditional Chinese medicine (TCM) plays an important role in the treatment of viral pneumonia during these outbreaks especially in SARS and SARS-CoV-2 because studies suggest that TCM formulations may target several aspects of the disease and may have lesser side effects than manufactured pharmaceuticals. In recent years, a lot of clinicians and researchers have made a series of in-depth explorations and investigations on the treatment of viral pneumonia with TCM, which have understood TCM therapeutic mechanisms more specifically and clearly. But critical analysis of this research in addition to further studies are needed to assess the potential of TCM in the treatment of viral pneumonia.

Keywords: traditional Chinese medicine, viral pneumonia, severe acute respiratory syndrome coronavirus, influenza virus, coronavirus induced disease 2019

\section{INTRODUCTION}

Viral pneumonia is an acute respiratory infectious disease caused by viruses with different degrees of contagiousness. The main clinical manifestation is fever, which may be accompanied by symptoms such as anhidrosis or sweating, nasal congestion, runny nose, sore throat and cough (Figueiredo, 2009). Common viruses that cause pneumonia include adenovirus, coronavirus, human metapneumovirus, rhinovirus, respiratory syncytial virus, influenza virus and parainfluenza virus (Jain, 2017). Among them, severe acute respiratory syndrome (SARS) coronavirus (SARS-CoV) in 
2003, Influenza A (H1N1) virus in 2009, and middle east respiratory syndrome coronavirus (MERS-CoV) in 2012 and severe acute respiratory syndrome coronavirus 2 (SARS-CoV-2) or called novel coronavirus in 2019 are highly contagious and fatal. As of 30 May 2020, there were 5,817,385 confirmed cases and 362,705 deaths in the coronavirus induced disease 2019 (COVID-19) outbreak since December 2019, and the trend is still on the rise (World Health Organization, 2020). At present, the commonly-used antiviral drugs in western medicine are probavirin, acyclovir, interferon, adenosine arabine, etc., which are easy to produce drug resistance, have many side effects and poor efficacy as well as other disadvantages (Amarelle et al., 2017). Because no specific and effective antiviral drugs have been developed in western medicine and Chinese herbal medicine possess clinical features of targeting multiple components and having multiple approaches, traditional Chinese medicine (TCM) has unique advantages in relieving symptoms, shortening treatment time and reducing the development of severe pneumonia. In the fight against COVID-19, the State Administration of Traditional Chinese Medicine of China has actively promoted the therapeutic role of TCM. As the member of the Leading Group of the National Health Commission and Secretary of the Leading Group of the National Administration of Traditional Chinese Medicine of China, Dr. Yanhong Yu pointed out that among the confirmed COVID-19 cases in China, a total of 74,187 people have used Chinese medicine, which accounts to $91.5 \%$ of patients (National Administration of Traditional Chinese Medicine, 2020). Academician of Chinese Academy of Engineering Dr. Boli Zhang analyzed 52 patients with COVID-19 retrospectively and found the clinical effective rate of $91.2 \%$ in patients treated with integrated traditional Chinese and western medicine as compared to effective rate of $61.1 \%$ in patients treated with western medicine alone (Xia et al., 2020).

Although there is no name of "viral pneumonia" in TCM, it is mainly attributed to "exogenous diseases" or "exterior syndrome". Traditional Chinese medical physicians usually classified them as "cough" or "lung distention" according to its clinical manifestations. Moreover, viral pneumonia with strong infectivity and high fatality rate is usually classified as "epidemic disease" in TCM. There has been a long history in China that TCM has been used to treat "epidemic disease" and there are a lot of clinical experiences and excellent efficacy. Therefore, different health organizations in China focus on TCM prevention and treatment of viral pneumonia and have formulated a series of diagnosis and treatment guidelines (China Association of Chinese Medicine, 2003; National Health and Family Planning Commission of People's Republic of China, 2015; National Health and Family Planning Commission of People's Republic of China, 2017; National Health Commission of the People's Republic of China and National Administration of Traditional Chinese Medicine, 2019; National Health Commission of the People's Republic of China, 2020). Among them, dozens of Chinese herbal medicines and formulae have been proposed (See Figures 1 and 2). Single traditional Chinese herbal medicine commonly-used in these diagnosis and treatment guidelines includes Gypsum Fibrosum (Shengshigao), Glycyrrhiza uralensis Fisch. ex DC. (Gancao), Prunus armeniaca L. (Xingren), Ephedra sinica Stapf (Mahuang), Scutellaria baicalensis Georgi (Huangqin), Artemisia annua L. (Qinghao), Lonicera japonica Thunb. (Jinyinhua), Forsythia suspensa (Thunb.) Vahl (Lianqiao), Lepidium apetalum Willd. (Tinglizi), Anemarrhena asphodeloides Bunge (Zhimu), Fritillaria thunbergii Miq. (Zhebeimu), Pogostemon cablin (Blanco) Benth. (Huoxiang) and Ophiopogon japonicus (Thunb.) Ker Gawl. (Maidong), etc. The recommended basic medical formulae for the treatment of viral pneumonia include the Ephedra, Apricot Kernel, Gypsum and Licorice Decoction (Maxingshigan Tang), which is used in the highest frequency (China Association of Chinese Medicine, 2003; Wang et al., 2011; National Health Commission of the People's Republic of China, 2020; Xi et al., 2020). For the main clinical manifestations of viral pneumonia such as fever, cough and panting, Gypsum Fibrosum (Shengshigao) can clear and discharge lung-heat, and vent pathogen with acrid-cool (medicinals). Prunus armeniaca L. (Xingren) and Ephedra sinica Stapf (Mahuang) can diffuse the lung, relieve cough and calm panting. Glycyrrhiza uralensis Fisch. ex DC. (Gancao) and Ephedra sinica Stapf (Mahuang) have antiviral and immune regulating effect (Mantani et al., 2001; Cinatl et al., 2003). Lonicera japonica Thunb. (Jinyinhua), Forsythia suspensa (Thunb.) Vahl (Lianqiao), Artemisia annua L. (Qinghao), Pogostemon cablin (Blanco) Benth. (Huoxiang), and Scutellaria baicalensis Georgi (Huangqin) are also commonly used in the recommended prescription and have been reported to possess immunoregulatory and antiviral activities (Efferth et al., 2008; Duan et al., 2012; Shen et al., 2012; Liu F. et al., 2016; Xu et al., 2019).

The role of Chinese herbal medicine in antivirus is usually considered interfering the procession of virus pathogenesis to achieve anti-virus effects, such as suppressing the virus proliferation, preventing the adhesion of virus into susceptible host cells, promoting the immune response, suppressing the excessive abnormal inflammatory response and regulating the immune function of the body. These antiviral effects are often referred to as "detoxification" or "resolving toxins" in the theory of traditional Chinese medicine (Xi and Gong, 2017). In recent years, many researches and progresses have been made to understand the action and mechanism of TCM in the treatment of viral pneumonia for clinical purpose. Through the collection and analysis of nearly 20 years of literature, these actions and mechanisms were discussed from the perspective of direct and indirect antiviral effects as well as immunomodulatory effects in this report.

\section{METHODS}

All data were retrieved from the PubMed, Web of Knowledge, China National Knowledge Infrastructure (CNKI), Wanfang Database, VIP Database, China Biology Medicine disc (CBMdisc) and official websites from January 1, 2000 to August 8, 2020 (including), and collected from the TCM 


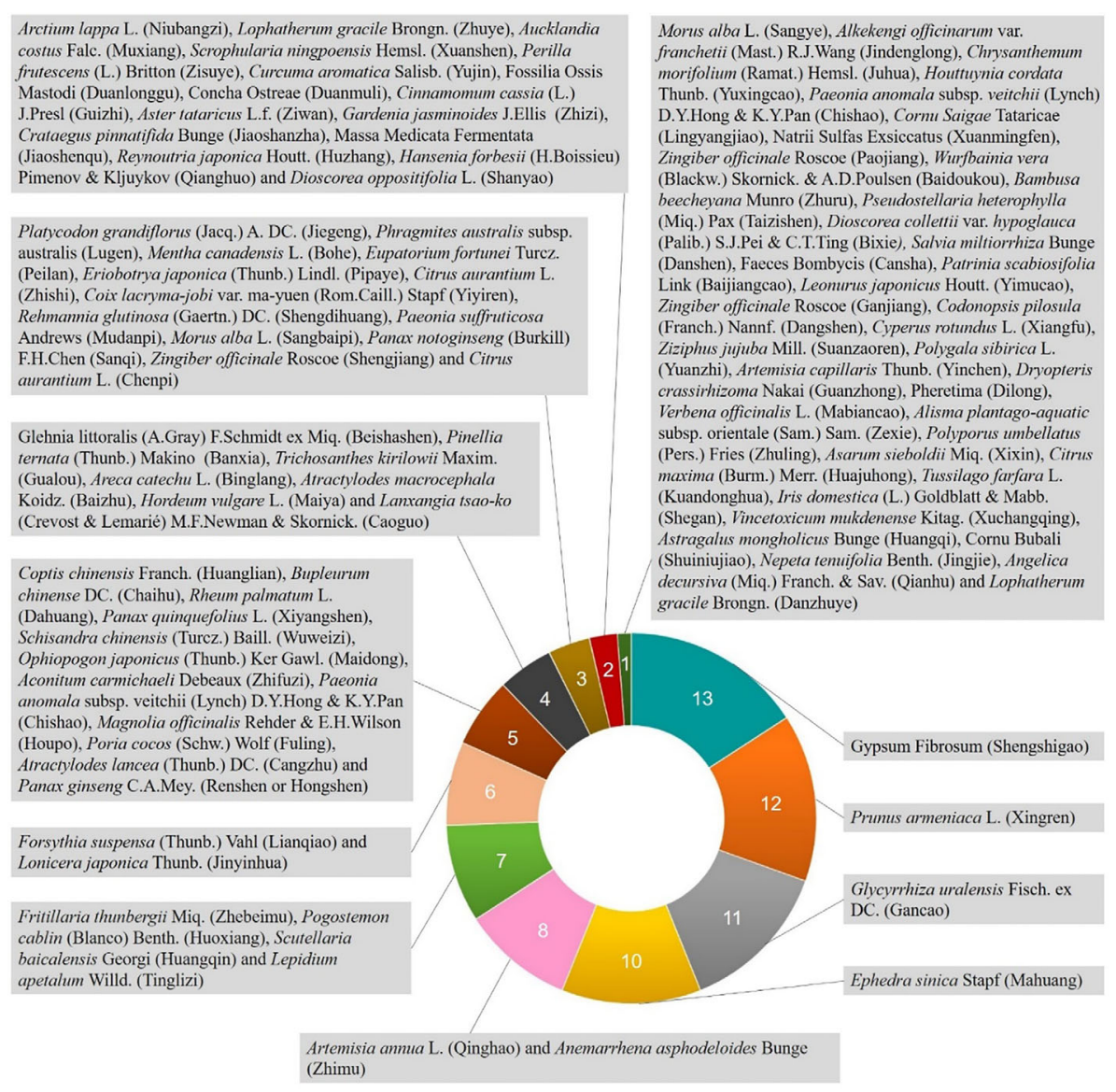

FIGURE 1 | Usage frequency of single herbal medicine in traditional Chinese medicine (TCM) part of the China National Guidelines of Diagnosis and Treatment for SARS-COV, MERS-CoV, SARS-CoV-2, and influenza virus (The statistical data were based on the analysis of each traditional Chinese herbal medicine involved in different syndromes of viral pneumonia in China's National Guidelines for TCM treatment of SARS-CoV, MERS-CoV, SARS-CoV-2, and influenza virus).

diagnosis and treatment literatures and data related to viral pneumonia issued by the National Health Commission of China, the Health Commissions of provinces, autonomous regions and municipalities directly under the central government, the State Administration of Traditional Chinese Medicine of China and the Administration of Traditional Chinese Medicine of all provinces, as well as the opinions expressed from TCM masters, academicians and famous TCM clinical experts through open channels. These date were extracted into two tables by two independent researchers according to the inclusion and exclusion criteria after reaching a consensus. When there are differences in the process of screening and data extraction, it was submitted to the third party for joint decision. The inclusion criteria included the following: $a$. Clear literatures on the experimental and clinical research on the treatment of viral pneumonia with herbs, herbal extracts, or Chinese medical formulae. $b$. Literatures written in English and Chinese. The exclusion criteria were as follows: $a$. Literatures without control medicinals in experimental research; $b$. Literature review, individual case report, expert experience introduction and other types of literature; $c$. For the content of the repeatedly published literature or the repeatedly quoted literature, only one article is included.

\section{RESULTS}

\section{Experimental Research}

Animal or cell studies have found that some traditional Chinese herbal medicines and medical formulas have a variety of pharmacological effects in the treatment of viral pneumonia. In addition to the direct or indirect antiviral effect (See Tables 1 and 2), the best advantage of TCM is the regulation of immune function and low adverse effects (Ma et al., 2013).

\section{Inhibition/Inactivation of Virus by TCM}

The antiviral activity of TCM first manifests as the inhibition or inactivation of the virus. Studies have shown that a variety of TCM can directly inactivate or prevent the virus from adsorbing or penetrating into the cells, or induce the body to produce substances such as interferon, thereby inhibiting the replication of the virus. 


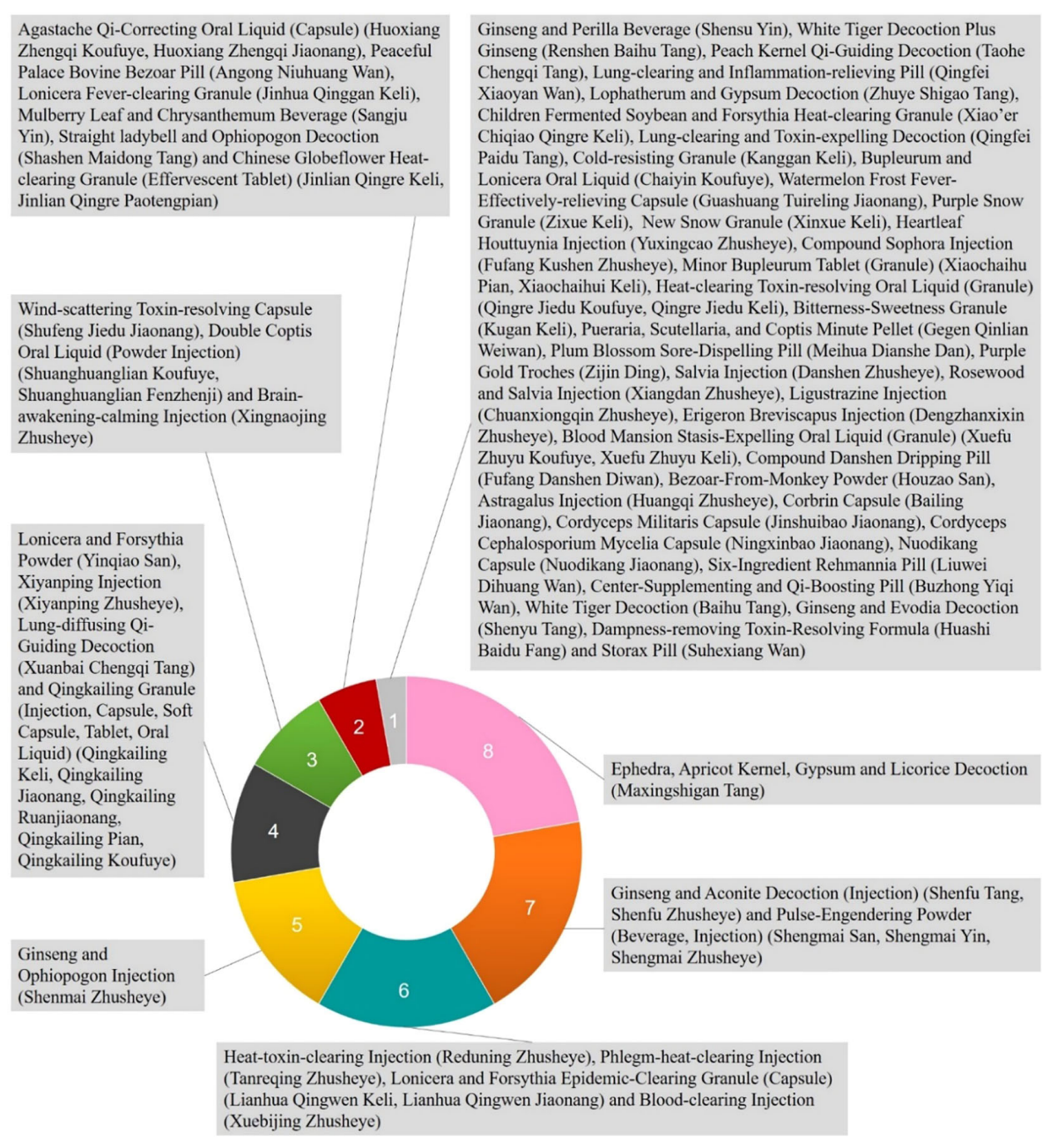

FIGURE 2 | Usage frequency of Chinese medical formulas and proprietary traditional Chinese medicine products in traditional Chinese medicine (TCM) part of the China National Guidelines of Diagnosis and Treatment for SARS-CoV, MERS-CoV, SARS-CoV-2, and influenza virus (The statistical data were based on the analysis of Chinese medical formulas and proprietary traditional Chinese medicine products involved in different syndromes of viral pneumonia in China's National Guidelines for TCM treatment of SARS-CoV, MERS-CoV, SARS-CoV-2, and influenza virus).

\section{Direct Inhibition of Viruses}

Virus first attaches to membrane of host cells and then enters cells. After dissociation of virus particle, virus will employ host cells to replicate its genes and process proteins for viral assembly and release. In view of this series of processes, the use of drugs in the pre-infection stages of the virus can play a direct inhibitory effect on the virus. Studies showed by MTT method that the volatile oil from Cinnamomum cassia (L.) J. Presl and Cinnamic aldehyde could significantly inhibit the proliferation of influenza A virus (H1N1) in MDCK (Madin-Darby canine kidney) cells $(p<0.05)$ (Liu et al., 2012). Ling Gou et al. confirmed that the medicated serum containing volatile oil from Nepeta tenuifolia Benth. and Cinnamomum cassia (L.) J. Presl also could significantly inhibit the proliferation of influenza A virus in MDCK cells $(p<0.05)$ and show a certain degree of direct killing of virus (Gou et al., 2013). Studies have shown that Glycyrrhizic acid from Glycyrrhiza uralensis Fisch. ex DC. not only directly inhibits the replication of coronavirus, but also acts on the early stage of virus adsorption and membrane penetration, which may be related to its activation of protein kinase C, casein kinase II and nuclear transcription factor B (Cinatl et al., 2003). Arctiin and its aglucone, arctigenin from the fruits of Arctium lappa L. showed potent in vitro antiviral activities against influenza A virus (A/NWS/33, H1N1) (IFV). Based on the data from time-of-addition experiments and on release tests of progeny viruses, arctigenin was assumed to interfere the early event(s) of viral replication after viral penetration into cells, and to suppress the release of progeny viruses from the host cells $(p<0.01$ or $p<0.001)$ (Hayashi et al., 2010). The classical Chinese medical formula, Pueraria Decoction (Gegen Tang) can play an antiviral role in the adsorption stage of virus $(p<0.01)$, and Pueraria decoction and its antiviral activity are positively correlated with dose (Geng et al., 2019). Neuraminidase (NA) can be another target molecule 


\begin{tabular}{|c|c|c|c|c|c|c|c|}
\hline Name of Herb & $\begin{array}{l}\text { Components contained/ } \\
\text { product }\end{array}$ & Model/Strains & $\begin{array}{l}\text { Dosage/ } \\
\text { Duration }\end{array}$ & $\begin{array}{c}\mathrm{IC}_{50}, \mathrm{EC}_{50}, \mathrm{TCID}_{50,} \mathrm{TC}_{50} \\
\mathrm{TC}_{0}, \mathrm{LD}_{50}, \mathrm{CD}_{50}{ }^{*}\end{array}$ & Control & Actions and mechanisms & References \\
\hline $\begin{array}{l}\text { Rhus chinensis Mill. } \\
\text { (Wubeizi) }\end{array}$ & $\begin{array}{l}\text { Ethyl acetate extract: acyl } \\
\text { pentagalic acid glucose, } \\
\text { ellagic acid and gallic acid } \\
\text { Ethanol extract: acyl } \\
\text { pentagalic acid glucose, } \\
\text { ellagic acid and gallic acid } \\
\text { Gallic acid }\end{array}$ & $\begin{array}{l}\text { In vitro: influenza virus } \\
\text { neuraminidase (NA) }\end{array}$ & $\begin{array}{l}10,25,50 \\
75,100 \\
\mathrm{mg} / \mathrm{L}\end{array}$ & $58.31 \mathrm{mg} / \mathrm{L}\left(\mathrm{IC}_{50}\right)$ & Amantadine & $\begin{array}{l}\text { Inhibits neuraminidase activity, restrain influenza } \\
\text { virus A/PR/8/34 (H1N1), inhibits the activation of } \\
\text { TLR4 and the downstream MyD88 dependent } \\
\text { transduction pathway, reduces the transcription } \\
\text { of inflammatory factors, and alleviates lung } \\
\text { inflammation and slow down the process of } \\
\text { acute lung injury. }\end{array}$ & $\begin{array}{l}\text { Yang et al., 2017; } \\
\text { Zhang et al., } 2018\end{array}$ \\
\hline $\begin{array}{l}\text { Osmunda japonica } \\
\text { Thunb. (Ziqiguanzhong) }\end{array}$ & Isoginkgetin & $\begin{array}{l}\text { In vitro: A/Califomia/04/ } \\
2009 \text { (H1N1) }\end{array}$ & 50 mg/L & $42.54 \pm 2.85 \mu \mathrm{mol} / \mathrm{L}\left(\mathrm{IC}_{50}\right)$ & Oseltamivir & $\begin{array}{l}\text { Inhibits neuraminidase activity, and plays an } \\
\text { anti-inflammatory role through IKB and c-JUN } \\
\text { pathway. }\end{array}$ & $\begin{array}{l}\text { Lang et al., 2019; Li } \\
\text { et al., } 2019\end{array}$ \\
\hline $\begin{array}{l}\text { Nepeta tenuifolia Benth. } \\
\text { (Jingjie) }\end{array}$ & $\begin{array}{l}\text { Volatile oil of Nepeta } \\
\text { tenuifolia } \\
\text { Pulegone } \\
\text { Menthone }\end{array}$ & $\begin{array}{l}\text { In vitro: } A / P R / 8 / 34 \\
\text { (H1N1) in MDCK }\end{array}$ & $\begin{array}{c}3.1 \times 10^{-3}- \\
0.10 \mathrm{mg} / \mathrm{ml} \\
\\
1.3 \times 10^{-2}- \\
0.10 \mathrm{mg} / \mathrm{ml} \\
\\
7.8 \times 10^{-3}- \\
0.10 \mathrm{mg} / \mathrm{ml}\end{array}$ & $\begin{array}{c}3.1 \times 10^{-3} \mathrm{mg} / \mathrm{ml}\left(I \mathrm{C}_{50}\right) ; 0.20 \\
\mathrm{mg} / \mathrm{ml}\left(\mathrm{TC}_{50}\right) ; 0.10 \mathrm{mg} / \mathrm{ml} \\
\left(\mathrm{TC}_{0}\right) \\
7.2 \times 10^{-3} \mathrm{mg} / \mathrm{ml}\left(I \mathrm{C}_{50}\right) ; 0.36 \\
\mathrm{mg} / \mathrm{ml}\left(\mathrm{TC}_{50}\right) ; 0.10 \mathrm{mg} / \mathrm{ml} \\
\left(\mathrm{TC}_{0}\right) \\
1.9 \times 10^{-3} \mathrm{mg} / \mathrm{ml}\left(I \mathrm{C}_{50}\right) ; 0.43 \\
\mathrm{mg} / \mathrm{ml}\left(\mathrm{TC}_{50}\right) ; 0.25 \mathrm{mg} / \mathrm{ml} \\
\left(\mathrm{TC}_{0}\right)\end{array}$ & Ribavirin & $\begin{array}{l}\text { Inhibits and kills influenza virus, increases the } \\
\text { content of IFN- } \alpha \text {, TLR7, IFN- } \beta \text { and IL- } 2 \text { and } \\
\text { inhibits the secretion of IL- } 6 \text { and TNF- } \alpha \text { in the } \\
\text { serum of mice, and restrains the protein } \\
\text { expression of Myd88 and TRAF6. }\end{array}$ & $\begin{array}{l}\text { Xie X. H. et al., 2007; } \\
\text { He et al., 2012; Gou } \\
\text { et al., 2013; He et al., } \\
2013\end{array}$ \\
\hline $\begin{array}{l}\text { Arctium lappa L. } \\
\text { (Niubangzi) }\end{array}$ & Arctigenin & $\begin{array}{l}\text { In vitro: A/FM1/1/47 } \\
\text { (H1N1) in MDCK }\end{array}$ & $\begin{array}{l}500,125 \\
31.25,7.81 \\
\quad \mathrm{mg} / \mathrm{ml}\end{array}$ & $31.25 \mathrm{mg} / \mathrm{ml}\left(\mathrm{IC}_{50}\right)$ & Ribavirin & $\begin{array}{l}\text { Inhibits the release of progeny viruses from the } \\
\text { host cells and induces interferon in vivo; and } \\
\text { improves the protein expression of IFN to } \\
\text { regulate human immune function. }\end{array}$ & $\begin{array}{l}\text { Tsou, 2007; Fu et al., } \\
\text { 2008; Hayashi et al., } \\
2010\end{array}$ \\
\hline $\begin{array}{l}\text { llex asprella (Hook. et } \\
\text { Arn.) Champ. ex Benth. } \\
\text { (Gangmei) }\end{array}$ & $\begin{array}{l}\text { Water extraction of llex } \\
\text { asprella root } \\
\text { Water extraction of llex } \\
\text { asprella stem }\end{array}$ & $\begin{array}{l}\text { In vitro: } \mathrm{A} / \mathrm{FM} 1 / 1 / 47 \\
(\mathrm{H} 1 \mathrm{~N} 1) \text { in } \mathrm{MDCK}\end{array}$ & $\begin{array}{c}50,12.5 \\
3.12,0.78 \\
\mathrm{mg} / \mathrm{ml}\end{array}$ & $\begin{array}{l}23.04 \mathrm{mg} / \mathrm{ml}\left(\mathrm{TC}_{50}\right) \\
10.82 \mathrm{mg} / \mathrm{ml}\left(\mathrm{TC}_{50}\right)\end{array}$ & Ribavirin & $\begin{array}{l}\text { Inhibits influenza virus type A FM1 strain, RSV } \\
\text { and parainfluenza virus type 3, increases the } \\
\text { percentage of CD3+ in peripheral blood T } \\
\text { lymphocyte subsets, and regulates the ratio of } \\
\text { CD4/CD8 to enhance the immune function of } \\
\text { mice. }\end{array}$ & Chen et al., 2016 \\
\hline $\begin{array}{l}\text { Reynoutria japonica } \\
\text { Houtt. (Huzhang) }\end{array}$ & Catechin-3-O-gallate & $\begin{array}{l}\text { In vitro: A/PR/8/34 } \\
\text { (H1N1) in MDCK } \\
\text { In vitro: A/Guangdong/ } \\
\text { 243/72 (H3N2) in MDCK } \\
\text { In vitro: A/PR/8/34 } \\
\text { (H1N1) in MDCK } \\
\text { In vitro: A/Guangdong/ } \\
\text { 243/72 (H3N2) in MDCK }\end{array}$ & $\begin{array}{c}31.25- \\
1,000 \mathrm{mg} / \mathrm{L}\end{array}$ & $\begin{array}{c}129.8 \mu \mathrm{mol} / \mathrm{L}\left(\mathrm{I} \mathrm{C}_{50}\right) ; 5.9 \\
\mu \mathrm{mol} / \mathrm{L}\left(\mathrm{EC}_{50}\right) \\
144.7 \mu \mathrm{mol} / \mathrm{L}\left(\mathrm{IC}_{50}\right) \\
21.3 \mu \mathrm{mol} / \mathrm{L}\left(\mathrm{IC}_{50}\right) ; 0.9 \\
\mu \mathrm{mol} / \mathrm{L}\left(\mathrm{EC}_{50}\right) \\
21.5 \mu \mathrm{mol} / \mathrm{L}\left(\mathrm{IC}_{50}\right)\end{array}$ & Zanamivir & $\begin{array}{l}\text { Inhibits neuraminidase activity, reduces lung } \\
\text { index, alleviates pulmonary edema, reduces } \\
\text { inflammatory factors TNF- } \alpha \text {, IL- } 1 \beta \text {, increases } \\
\text { Pl3K protein expression, and reduces the } \\
\text { protein expression of p-Akt, caspase- } 3 \text { and NF- } \\
\text { KB. }\end{array}$ & $\begin{array}{l}\text { Chen et al., 2012; Li } \\
\text { M. et al., } 2020\end{array}$ \\
\hline $\begin{array}{l}\text { Isatis tinctoria L. } \\
\text { (Banlangen) }\end{array}$ & $\begin{array}{l}\text { Isatis root polysaccharide } \\
\text { (IRP) } \\
\text { Acid Isatis root } \\
\text { polysaccharide (IRPA) } \\
\text { Neutral Isatis root } \\
\text { polysaccharide (IRPN) } \\
\text { Isatis root polysaccharide } \\
\text { (IRP) }\end{array}$ & $\begin{array}{l}\text { In vitro: A/Califomia/04/ } \\
2009 \text { (H1N1), A/Anhui/1/ } \\
2005 \text { (H5N1) in } \\
\text { Fluorescein-n- } \\
\text { acetylneuraminic acid } \\
\text { solution } \\
\text { In vitro: A/Califomia/04/ } \\
2009 \text { (H1N1), A/Anhui/1/ } \\
2005 \text { (H5N1) in }\end{array}$ & $\begin{array}{l}0.5-35 \mathrm{mg} / \\
\mathrm{ml}\end{array}$ & $\begin{array}{l}\text { H1N1: } 24.13 \mathrm{mg} / \mathrm{ml}\left(\mathrm{IC}_{50}\right) \\
\text { H5N1: } 22.91 \mathrm{mg} / \mathrm{ml}\left(\mathrm{IC}_{50}\right) \\
\text { H1N1: } 5.88 \mathrm{mg} / \mathrm{ml}\left(\mathrm{IC}_{50}\right) ; \\
\text { H5N1: } 4.12 \mathrm{mg} / \mathrm{ml}\left(\mathrm{IC}_{50}\right) \\
\text { H1N1: } 52.34 \mathrm{mg} / \mathrm{ml}\left(\mathrm{IC}_{50}\right) \\
\text { H5N1: } 49.39 \mathrm{mg} / \mathrm{ml}\left(\mathrm{IC}_{50}\right) \\
\text { H1N1: } 25.66 \mathrm{mg} / \mathrm{ml}\left(\mathrm{IC}_{50}\right) \\
\text { H5N1: } 23.10 \mathrm{mg} / \mathrm{ml}\left(\mathrm{IC}_{50}\right)\end{array}$ & $\begin{array}{l}\text { Oseltamivir, } \\
\text { apigenin }\end{array}$ & $\begin{array}{l}\text { Inhibits neuraminidase activity in influenza virus } \\
\text { H1N1 and H5N1, and decrease the protein } \\
\text { expression of IFN- } \beta \text { by downregulating the } \\
\text { expression of TLR3, TBK1 and p-IRF3 in } \\
\text { RAW264.7 cells infected by respiratory syncytial } \\
\text { virus (RSV), attenuates inflammation, and } \\
\text { decreases H1N1 viral replications in lungs, } \\
\text { reduces the protein expression of mitofusin-2 }\end{array}$ & $\begin{array}{l}\text { Li et al., 2009; Li J, } \\
\text { 2013; Hou et al., } \\
\text { 2017; Luo et al., } \\
2019\end{array}$ \\
\hline
\end{tabular}




\section{Name of Herb \\ Components contained/ \\ product \\ Acid Isatis root \\ polysaccharide (IRPA) \\ Neutral Isatis root \\ polysaccharide (IRPN) \\ Gardenia jasminoides J. Geniposide, Gardenia}

Ellis (Zhizi)

extract ZG

Hypericum perforatum L. Hypericin, hyperoside (Guanyelianqiao)

$\begin{array}{ll}\text { Andrographis paniculata } & \text { Water extraction of } \\ \text { (Burm.f.) Nees } & \text { Andrographis panicula }\end{array}$

Andrographis paniculata

(Chuanxinlian)

Ethanol extraction of

Andrographis paniculata

Water extraction of

Andrographis paniculata

Lonicera japonica

Thunb. (Jinyinhua)

$$
\text { acid }
$$

Scutellaria baicalensis

Georgi (Huangqin)

\section{Baicalin}

Coptis chinensis Franch. Berberine

(Huanglian) and

Berberine: magnolol (1:5)

Magnolia officinalis

Rehder \& E.H.Wilson

Berberine: magnolol (2:5)

Berberine: magnolol (1:1)

Berberine: magnolol (3:2)

Berberine: magnolol (5:2)

Berberine: magnolol (5:1)
Berberine: magnolol (2:3)

\section{Model/Strains}

Dosage/

\section{$\mathrm{IC}_{50}, \mathrm{EC}_{50}, \mathrm{TCID}_{50}, \mathrm{TC}_{50}$, Control}

$\mathrm{TC}_{0}, \mathrm{LD}_{50}, \mathrm{CD}_{50}$

Fluorescein-4,7-

dimethoxy-n-

acetylneuraminic acid

solution

In vitro: $A 3 / G u i f a n g / 81 /$

23 (H3N2) in A549

$\mu \mathrm{g} / \mathrm{ml}$

N1: $6.09 \mathrm{mg} / \mathrm{ml}\left(\mathrm{IC}_{50}\right)$;

H5N1: $5.08 \mathrm{mg} / \mathrm{ml}\left(\mathrm{IC}_{50}\right)$

H1N1: $55.19 \mathrm{mg} / \mathrm{ml}\left(\mathrm{IC}_{50}\right)$;

H5N1: $52.16 \mathrm{mg} / \mathrm{ml}\left(\mathrm{IC}_{50}\right)$

$50-60 \mu \mathrm{g} / \mathrm{ml}\left(\mathrm{IC}_{50}\right) \quad$ Ribavirin

$/ \mathrm{ml}$
In vitro: 2337/A

Gansuchengguan/1771/

100,50

2006 (H1N1) in MDCK

$25,12.5$

$\mu \mathrm{g} / \mathrm{ml}$

In vitro: A/FM1/1/47

(H1N1) in MDCK

$250,62.5$

$15.63,3.9$

$0.98,0.24$

$\mathrm{mg} / \mathrm{ml}$

In vitro: influenza virus A/ $\quad 8.2 \mathrm{~g} / \mathrm{m}$

Chicken/Thailand/CUK2/

04 (H5N1) in MDCK

In vitro: influenza A

(H3N2) in MDCK

In vitro: Influenza A

(H1N1) in MDCK

In vitro: A/FM1/1/47

(H1N1) in MDCK/A549

In vitro: A/Beijing/32/92

(H3N2) in MDCK or

A549

10-4.90/0.1 $\mathrm{ml}\left(\mathrm{TCID}_{50}\right) ; 200$ Oseltamivir $\mu \mathrm{g} / \mathrm{ml}\left(\mathrm{TC}_{0}\right)$

10-3.50/0.1 ml (TCID 50$) ; 250$ Ribavirin $\mathrm{mg} / \mathrm{ml}\left(\mathrm{TC}_{0}\right)$

$8.2 \mu \mathrm{g} / \mathrm{ml}\left(\mathrm{CD}_{50}\right)$

$380.3 \mu \mathrm{g} / \mathrm{ml}\left(\mathrm{CD}_{50}\right)$

$5 \mathrm{mg} / \mathrm{ml} \quad 236.28 \pm 15.37 \mu \mathrm{g} / \mathrm{ml}\left(\mathrm{IC}_{50}\right) \quad$ Ribavirin

$290.50 \pm 34.82 \mu \mathrm{g} / \mathrm{ml}\left(\mathrm{IC}_{50}\right)$

$20,30,40$

$60,80 \mu \mathrm{g} /$

$\mathrm{ml}$ (in

MDCK); 5 ,

10, 20, 30,

$40 \mu \mathrm{g} / \mathrm{ml}$

(in A549)

In vivo: A/FM1/1/47 50, 100

(H1N1) in mice

$200 \mathrm{mg} / \mathrm{kg} /$

In vivo: A/Beijing/32/92

day

(H3N2) in mice

In vitro: influenza virus $\quad 32,16,8.0$,

neuraminidase (NA)

4.0, 2.0,

$4.0,2.0$,
$1.0,0.5$

$\mathrm{mg} / \mathrm{ml}$
43.3/40.3 $\mu \mathrm{g} / \mathrm{ml}\left(\mathrm{EC}_{50}\right) \quad$ Ribavirin

104.9/100.1 $\mu \mathrm{g} / \mathrm{ml}\left(\mathrm{EC}_{50}\right)$

$52.3 \mu \mathrm{mol} / \mathrm{L}\left(\mathrm{IC}_{50}\right)$

$85.8 \mu \mathrm{mol} / \mathrm{L}\left(\mathrm{IC}_{50}\right)$

$21.10 \mathrm{mg} / \mathrm{ml}\left(I_{50}\right)$

$19.09 \mathrm{mg} / \mathrm{ml}\left(\mathrm{IC}_{50}\right)$

$15.39 \mathrm{mg} / \mathrm{ml}\left(\mathrm{IC}_{50}\right)$

$3.80 \mathrm{mg} / \mathrm{ml}\left(\mathrm{IC}_{50}\right)$

$13.66 \mathrm{mg} / \mathrm{ml}\left(\mathrm{IC}_{50}\right)$

$8.90 \mathrm{mg} / \mathrm{ml}\left(\mathrm{IC}_{50}\right)$

$19.04 \mathrm{mg} / \mathrm{ml}\left(\mathrm{IC}_{50}\right)$
$3.53 \mathrm{mg} / \mathrm{ml}\left(\mathrm{IC}_{50}\right)$
Actions and mechanisms

References

(MFN2) to reduce the susceptibility to influenza

virus via mitochondrial antiviral signaling.

Decreases the protein expression of $\|-6$, TNF $\alpha$, Guo et al, 2007:

TLR3 and NF-KB and mRNA expression of

TLR7/MyD88 and TRIF in lung tissue of H3N2

infected mice, and improve cell membrane

fluidity.

Increases the function of $\mathrm{T}$ and $\mathrm{B}$ lymphocyte

conversion, phagocytic function of

macrophages and NK killing activity of influenza

virus-infected mice, decreases the content of IL6 and TNF- $\alpha$ and increases the protein

expression of IFN- $\gamma$ and IL-10 in lung tissue and serum of mice.

Increases the percentage of CD3+ in peripheral Sornpet et al., 2017; blood T lymphocyte subsets, regulates the ratio Wang et al., 2019 of $C D 4 / C D 8$, enhances the immune function of mice, and shows antiviral activity against H5N1 virus.

nhibits the influenza virus proliferation and neuraminidase activity, increases the content of IFN- $\gamma$ in serum, and decrease the lung index.

Inhibits neuraminidase activity, reduces virus replication, and decreases the protein

expression of TLR3 and NF-kB and mRNA expression of TRIF, the protein and gene

expression of proinflammatory cytokines TNF- $\alpha$ $\mathrm{L}-1$ and IL-6 in lung tissue, and increases the protein and gene expression of anti-

inflammatory cytokine IL-10 and antiviral factor IFN- $\gamma$ in lung tissue after infection.

Inhibits neuraminidase activity, restrain influenza A (H1N1) virus, reduce the lung index of infected mice and ameliorates the lung

pathological changes, suppresses the viral infection-induced up-regulation of TLR7 signaling pathway, such as TLR7, MyD88, and

NF-kB (p65), at both the mRNA and protein levels, and inhibits the viral infection-induced
Wang Y. F. et al., 2020

Wang et al., 2009;

Xu et al., 2016

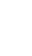

Shen et al., 2012; Zhu et al., 2018; Zhao et al., 2020

Ding et al., 2014; Wang et al., 2014; Zhang and Yu, 2010; Xu et al., 2019 


\begin{tabular}{|c|c|c|c|c|c|c|c|}
\hline Name of Herb & $\begin{array}{l}\text { Components contained/ } \\
\text { product }\end{array}$ & Model/Strains & $\begin{array}{l}\text { Dosage/ } \\
\text { Duration }\end{array}$ & $\begin{array}{l}\mathrm{IC}_{50}, \mathrm{EC}_{50}, \mathrm{TCID}_{50}, \mathrm{TC}_{50} \\
\mathrm{TC}_{0}, \mathrm{LD}_{50}, \mathrm{CD}_{50} \text { * }\end{array}$ & Control & Actions and mechanisms & References \\
\hline & $\begin{array}{l}\text { Magnolol } \\
\text { Berberine: magnolol (1:1) }\end{array}$ & $\begin{array}{l}\text { In vivo: } \mathrm{A} / \mathrm{PR} / 8 / 34 \\
\text { (H1N1) in mice }\end{array}$ & $8 \mathrm{~g} / \mathrm{kg}$ & $\begin{array}{l}19.37 \mathrm{mg} / \mathrm{ml}\left(\mathrm{IC}_{50}\right) \\
10^{-2.5} / 100 \mu \mathrm{l}\left(\mathrm{LD}_{50}\right)\end{array}$ & Ribavirin & $\begin{array}{l}\text { increase in Th1/Th2 and Th17/Treg ratios as } \\
\text { well as the production of inflammatory } \\
\text { cytokines. }\end{array}$ & \\
\hline \multirow[t]{2}{*}{$\begin{array}{l}\text { Ephedra sinica Stapf } \\
\text { (Mahuang) }\end{array}$} & (+) - Catechin & $\begin{array}{l}\text { In vitro: A/California/O7/ } \\
2009 \text { (H1N1) in MDCK }\end{array}$ & $25 \mu \mathrm{g} / \mathrm{ml}$ & $18.4 \pm 0.7 \mu \mathrm{g} / \mathrm{ml}\left(\mathrm{EC}_{50}\right)$ & Amantadine & \multirow{2}{*}{$\begin{array}{l}\text { Suppresses the proliferation of influenza virus } \\
\text { H1N1 and neuraminidase activity, and inhibits } \\
\text { the adsorption and penetration of respiratory } \\
\text { syncytial virus. }\end{array}$} & \multirow{2}{*}{$\begin{array}{l}\text { Mantani et al., 2001; } \\
\text { You et al., 2018; } \\
\text { Zhu, } 2008\end{array}$} \\
\hline & $\begin{array}{l}\text { Water extract of Ephedra } \\
\text { sinica }\end{array}$ & $\begin{array}{l}\text { In vitro: respiratory } \\
\text { syncytial virus (RSV) in } \\
\text { Hela }\end{array}$ & $\begin{array}{c}5.00,4.00 \\
3.20,2.56 \\
\mathrm{mg} / \mathrm{ml}\end{array}$ & $3.74 \mathrm{mg} / \mathrm{ml}\left(\mathrm{EC}_{50}\right)$ & Ribavirin & & \\
\hline \multirow[t]{2}{*}{$\begin{array}{l}\text { Forsythia suspensa } \\
\text { (Thunb.) Vahl (Lianqiao) }\end{array}$} & $\begin{array}{l}\text { Ethanol extract: } \\
\text { Forsyshiyanins A-B, }\end{array}$ & $\begin{array}{l}\text { In vitro: A/PR/8/34 } \\
\text { (H1N1) in MDCK }\end{array}$ & $10 \mu \mathrm{M}$ & $18.4-26.2 \mu \mathrm{M}\left(\mathrm{IC}_{50}\right)$ & \multirow[t]{2}{*}{ Ginkgolide B } & $\begin{array}{l}\text { Forsyshiyanins A-B inhibit NP gene expression } \\
\text { of influenza A virus after transfection. }\end{array}$ & \multirow{2}{*}{$\begin{array}{l}\text { Duan et al., 2012; } \\
\text { Law et al., 2017; } \\
\text { Zhao et al., } 2020\end{array}$} \\
\hline & Forsythiaside (Phillyrin) & $\begin{array}{l}\text { In vitro: respiratory } \\
\text { syncytial virus (RSV) } \\
\text { Long in Hep-2 }\end{array}$ & & $10.5-14.4 \mu \mathrm{M}\left(\mathrm{EC}_{50}\right)$ & & $\begin{array}{l}\text { Forsythoside A reduces the viral titers of } \\
\text { different influenza virus subtypes in cell cultures } \\
\text { and increases the survival rate of the mice in an } \\
\text { in vivo influenza virus infection model, and } \\
\text { reduces the influenza M1 protein, which in turn } \\
\text { intervenes the budding process of the newly } \\
\text { formed virions. }\end{array}$ & \\
\hline \multirow[t]{2}{*}{$\begin{array}{l}\text { Morus alba L. } \\
\text { (Sangbaipi) }\end{array}$} & $\begin{array}{l}\text { Cortex mori polysaccharide, } \\
\text { total flavonoids of Cortex } \\
\text { mori }\end{array}$ & $\begin{array}{l}\text { In vitro: respiratory } \\
\text { syncytial virus (RSV) } \\
\text { Long in Hep-2 }\end{array}$ & - & $10^{-2.25} / 100 \mu \mathrm{l}\left(\mathrm{TCID}_{50}\right)$ & \multirow[t]{2}{*}{ Ribavirin } & $\begin{array}{l}\text { Inhibits respiratory syncytial virus, reduces the } \\
\text { infiltration of inflammatory cells in alveolar wall to } \\
\text { ameliorate the inflammatory status of lung }\end{array}$ & \multirow{2}{*}{$\begin{array}{l}\text { Dong et al., 2016a; } \\
\text { Dong et al., 2016b; } \\
\text { Liu, } 2016\end{array}$} \\
\hline & $\begin{array}{l}\text { Cortex mori polysaccharide } \\
\text { Total flavonoids of Cortex } \\
\text { mori }\end{array}$ & $\begin{array}{l}\text { In vivo: respiratory } \\
\text { syncytial virus (RSV) } \\
\text { Long in mice }\end{array}$ & $\begin{array}{l}91 \mathrm{mg} / \mathrm{kg} / \\
\text { day } \\
114 \mathrm{mg} / \mathrm{kg} / \\
\text { day }\end{array}$ & $10^{-1.92} / 100 \mu \mathrm{l}\left(L D_{50}\right)$ & & $\begin{array}{l}\text { tissue, promotes cell immune adjustment in } \\
\text { mice infected by respiratory syncytial virus, } \\
\text { decreases the protein expression of PI3K, Akt1/ } \\
2 \text { and NF-kBp65 in lung tissue of mice as well } \\
\text { as the IL-4 and INF- } \gamma \text { in serum. }\end{array}$ & \\
\hline \multirow[t]{5}{*}{$\begin{array}{l}\text { Houttuynia cordata } \\
\text { Thunb. (Yuxingcao) }\end{array}$} & Quercetin, isoquercetin & $\begin{array}{l}\text { In vitro: Influenza A } \\
(\mathrm{H} 3 \mathrm{~N} 2) \text { in MDCK }\end{array}$ & $5 \mathrm{mg} / \mathrm{ml}$ & & \multirow[t]{2}{*}{ Ribavirin } & $\begin{array}{l}\text { Houttuynia cordata Thunb. extract, quercetin } \\
\text { and cinanserin inhibit the activity of murine }\end{array}$ & \multirow{5}{*}{$\begin{array}{l}\text { Chiow et al., 2016; } \\
\text { Zhu et al., 2018; Ling } \\
\text { et al., } 2020\end{array}$} \\
\hline & & $\begin{array}{l}\text { In vitro: Influenza A } \\
\text { (H1N1) in MDCK }\end{array}$ & & $522.28 \pm 36.48 \mu \mathrm{g} / \mathrm{ml}\left(\mathrm{IC}_{50}\right)$ & & & \\
\hline & $\begin{array}{l}\text { Ethyl acetate }(E A) \text { fraction of } \\
\text { Houttuynia cordata Thunb. }\end{array}$ & $\begin{array}{l}\text { In vitro: Murine } \\
\text { coronavirus }\end{array}$ & $\begin{array}{c}0.24-3.91 \\
\mathrm{mg} / \mathrm{ml}\end{array}$ & & \multirow[t]{3}{*}{ Rutin } & $\begin{array}{l}\text { virus in vitro. Quercitrin inhibites both viral } \\
\text { replication and TLR signaling in cells. Flavonoids }\end{array}$ & \\
\hline & Quercetin & & $\begin{array}{l}15.63- \\
500.00 \mathrm{mg} / \\
\mathrm{ml}\end{array}$ & $125.00 \mu \mathrm{g} / \mathrm{ml}\left(\mathrm{IC}_{50}\right)$ & & $\begin{array}{l}\text { from Houttuynia cordata attenuate } \mathrm{H} 1 \mathrm{~N} 1 \text { - } \\
\text { induced acute lung injury in mice via inhibition of } \\
\text { influenza virus and Toll-like receptor signaling. }\end{array}$ & \\
\hline & $\begin{array}{l}\text { Cinanserin (1 dpi)Cinanserin } \\
\text { (2 dpi) }\end{array}$ & & $\begin{array}{l}3.91- \\
125.00 \mathrm{mg} / \\
\mathrm{ml}\end{array}$ & $\begin{array}{c}31.25 \mu \mathrm{g} / \mathrm{ml}\left(\mathrm{I} \mathrm{C}_{50}\right) 62.50 \mu \mathrm{g} / \\
\mathrm{ml}\left(\mathrm{IC}_{50}\right)\end{array}$ & & & \\
\hline \multirow[t]{5}{*}{$\begin{array}{l}\text { Cinnamomum cassia (L.) } \\
\text { J.Presl (Guizhi) }\end{array}$} & Cinnamic aldehyde & $\begin{array}{l}\text { In vitro: } \mathrm{A} / \mathrm{PR} / 8 / 34 \\
\text { (H1N1) in MDCK }\end{array}$ & $\begin{array}{l}0.132 \\
0.264 \mathrm{mg} / \\
\mathrm{kg}\end{array}$ & $5.31 \times 10^{-5} \mathrm{mg} / \mathrm{ml}\left(\mathrm{IC}_{50}\right)$ & \multirow[t]{5}{*}{ Ribavirin } & $\begin{array}{l}\text { Inhibits the proliferation of influenza A virus } \\
\text { (H1N1) in MDCK cells, restrains the infection by } \\
\text { interfering with endocytosis, kills influenza virus, }\end{array}$ & \multirow{5}{*}{$\begin{array}{l}\text { Liu et al., 2012; Gou } \\
\text { et al., 2013; Liu et al., } \\
\text { 2013; Zhuang et al., } \\
2009\end{array}$} \\
\hline & Volatile oil of Cassia twig & & $\begin{array}{l}0.174 \\
0.348 \mathrm{mg} / \\
\mathrm{kg}\end{array}$ & $5.80 \times 10^{-5} \mathrm{mg} / \mathrm{ml}\left(\mathrm{IC}_{50}\right)$ & & $\begin{array}{l}\text { and increases the content of IFN- } \alpha \text { and IFN- } \beta \text { in } \\
\text { the serum of H1N1-infected mice. }\end{array}$ & \\
\hline & Cinnamomi Cortex extract & In vitro: wild-type SARS- & $0.1,0.2$ & $43.1 \pm 2.8 \mu \mathrm{g} / \mathrm{ml}\left(\mathrm{IC}_{50}\right)$ & & & \\
\hline & $\begin{array}{l}\text { Ethanol extract of } \\
\text { Cinnamomi Cortex }\end{array}$ & CoV in Vero E6 cells & $0.3 \mathrm{mg} / \mathrm{ml}$ & & & & \\
\hline & & & & $7.8 \pm 0.3 \mu \mathrm{g} / \mathrm{ml}\left({ }^{\prime} \mathrm{C}_{50}\right)$ & & & \\
\hline
\end{tabular}




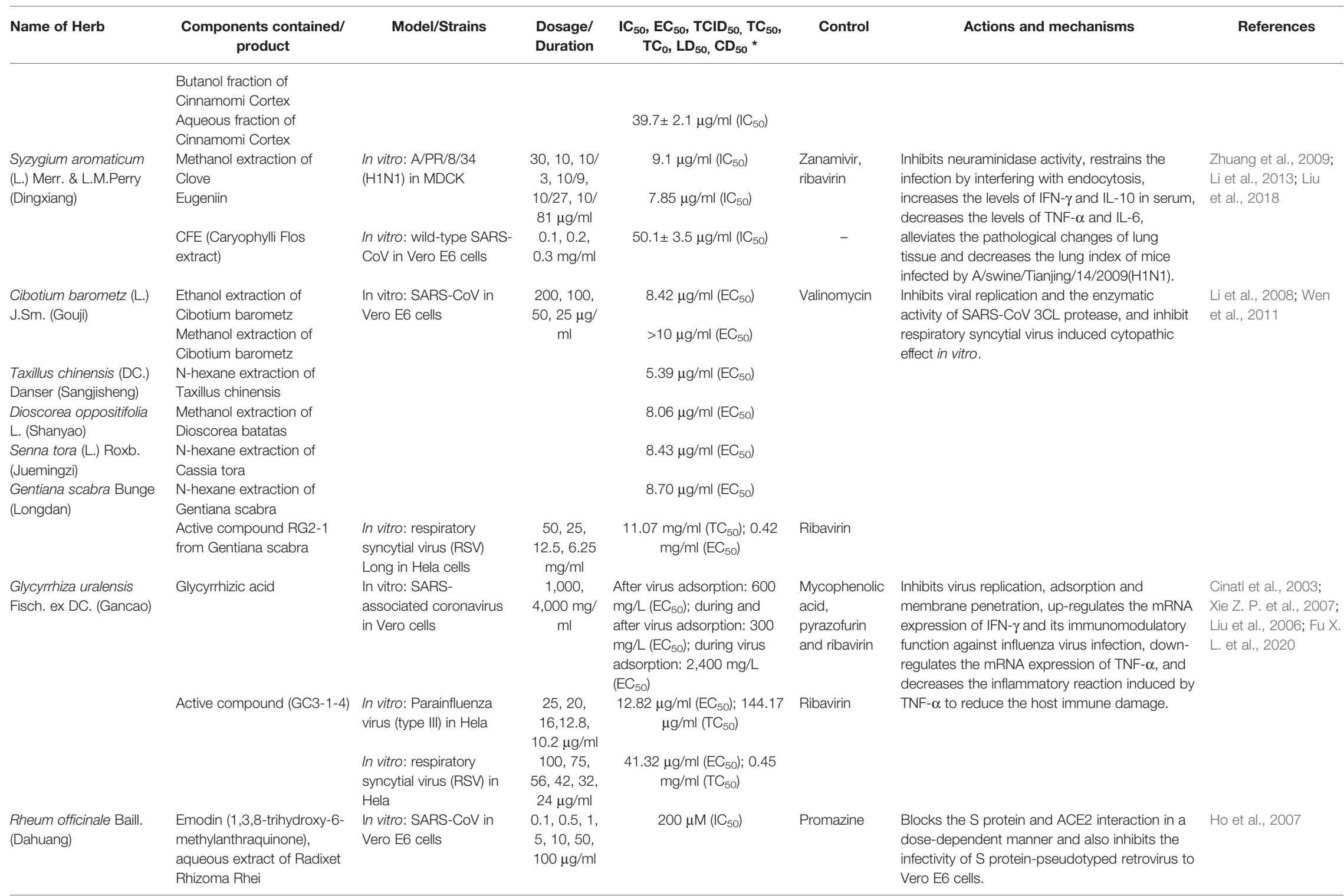

${ }^{*} C_{50}, 50 \%$ inhibiting concentration; $E C_{50}, 50 \%$ maximal effective concentration; $T C I D_{50}, 50 \%$ tissue culture infectious dose; $T C_{50}$, median toxic concentration. $T C_{0}$, Maximum nontoxic concentration; $L D_{50}$, median lethal dose; $C D_{50}, 50 \%$ cytotoxicity dose. 
for antiviral effect. Neuraminidase is a mushroom cloud tetramer glycoprotein located on the envelope of influenza virus and involved in virus release and spread. Jiawei Liu et al. used chromatographic separation technology to screen and isolate Eugeniin, an effective compound from Syzygium aromaticum (L.) Merr. \& L.M.Perry, showing that it could inhibit neuraminidase activity of H1N1 in vitro (Liu et al., 2018). Studies by Kaotan Chen et al. showed that resveratrol, (E)3,5,12-trihydroxystilbene-3-O- $\beta$-D-glucopy-ranoside-2' $\left(3^{\prime \prime}, 4^{\prime \prime}, 5^{\prime \prime}\right.$-trihydroxybenzoate) and Catechin-3-O-gallate, three extracts of Reynoutria japonica Houtt., could effectively inhibit neuraminidase activity (Chen et al., 2012). Baicalin is a flavonoid in Scutellaria baicalensis Georgi. Studies by Yue Ding et al. have confirmed that baicalin can significantly inhibit the neuraminidase activity of influenza A (H1N1) virus $(p<0.05$ or $p<0.01$ ) (Ding et al., 2014). Han-Bing Li et al. found that acidic sugars in Isatis tinctoria L. had higher inhibitory activity of neuraminidase than neutral sugars and total sugars. Moreover, acidic sugars were slightly stronger to inhibit activity of neuraminidase in $\mathrm{H} 5 \mathrm{~N} 1$ influenza virus than that in $\mathrm{H} 1 \mathrm{~N} 1$ virus $(p<0.05)$ (Li et al., 2009). Xianying Yang et al. used UPLC-Q-TOF-MS (Ultra-high performance liquid chromatography coupled with a four-pole time-of-flight mass spectrometer) to detect the neuraminidase inhibitory activity of Rhus chinensis Mill., and found that ethyl acetate, ethanol extract, acyl-pentagalic glucose, ellagic acid and gallic acid from Wubeizi exhibit different levels of neuraminidase inhibitory activity (Yang et al., 2017). Studies by Shuang Lang et al. showed that the compound Iso-ginkgo biloba diflavone extracted from Osmunda japonica Thunb. has a significant inhibitory effect on the neuraminidase activity of influenza virus (Lang et al., 2019). Gao Chen et al. evaluated the ratio of combination of two Chinese medicines of Coptis chinensis Franch. and Magnolia officinalis Rehder \& E.H. Wilson and found that the best inhibitory effect on neuraminidase was at 1:1 ratio (Chen et al., 2017). Traditional Chinese medical formulae and proprietary traditional Chinese medicine products such as Ephedra, Apricot Kernel, Gypsum and Licorice Decoction (Maxingshigan Tang), medicated serum of Folium Ginkgo and Ephedra Lung-clearing Capsule (Yinhuang Qingfei Jiaonang), as well as Heat-toxin-clearing Injection (Reduning Zhusheye) also exhibit inhibitory effect of neuraminidase $(p<0.05$ or $p<0.01)$ (Hsieh et al., 2012; Sun et al., 2014; Li et al., 2015).

\section{Indirect Inhibition of Viruses}

Interferon is a glycoprotein produced by cells stimulated by viruses or other interferon inducers. After binding to interferon receptors, it can induce cells to produce antiviral proteins with enzyme activity, such as protein kinase and 2',5'-adenosine kinase (Der and Lau, 1995; Min and Krug, 2006), thereby inhibiting viral replication. Studies by Rong Liu et al. showed that the volatile oil and cinnamaldehyde contained in Cinnamomum cassia (L.) J.Presl could increase the content of IFN- $\alpha$ and IFN- $\beta$ in serum of mice with viral pneumonia $(p<0.05)$ (Liu et al., 2013). Ting $\mathrm{He}$ et al. documented that Nepeta tenuifolia Benth. can increase the levels of IFN- $\alpha$, IFN- $\beta$ and IL-2 in virus-infected mice $(p<0.05$ or $p<0.01)$ (He et al., 2013). Hongri Xu et al. showed that Scutellaria baicalensis Georgi could increase the expression of the antiviral factor IFN- $\gamma$ in lung tissue $(p<0.05)$ (Xu et al., 2019). Cheng-Chuan Tsou pointed out that the antiviral effect of Arctium lappa L. was related to its ability to induce the organism to produce interferon $(p<0.05$ or $p<0.01$ ) (Tsou, 2007).

\section{Regulatory Effects on Immune and Cellular Inflammatory Factors}

Excessive immune response and release of inflammatory cytokines are important causes of viral pneumonia and lung injury. In patients infected with SARS, Influenza A (H1N1) virus and SARS-CoV-2 (Li et al., 2012; Casadevall and Pirofski, 2014; Huang et al., 2020), abnormally-elevated inflammatory cytokines so called cytokine storm can be detected and are closely related to disease severity. Therefore, inhibiting the overexpression of inflammatory factors and improving immune function have become important part in the treatment of viral pneumonia.

\section{Regulation of the TLR-NF- $\kappa B$ Signaling Pathway}

The TLR-NF- $\kappa B$ signaling pathway is an important pathway that mediates the expression of inflammatory factors. Toll-like receptor (TLR) is a transmembrane protein located on the cell membrane, which is composed of extracellular region, transmembrane region and intracellular region. At present, there are three kinds of TLR3, TLR7 and TLR8 which are closely related to the virus. These three receptors plus TLR9 have functional domain inside the cell, while the rest of the receptors are expressed outside the cell. Whether the different distribution of this functional domain is related to its antiviral effect needs further study. After virus invasion, both TLR3mediated MyD88 independent signaling and TLR7-mediated MyD88-dependent signaling ultimately activate the nuclear transcription factor $\mathrm{NF}-\kappa \mathrm{B}$, which induces and promotes the expression of preinflammatory factors (Sanjeewa et al., 2020). Yongfeng Wang et al. and Li Wang et al. established a mouse model of influenza viral pneumonia and found that gardenin from Gardenia jasminoides J.Ellis and baicalin from Scutellaria baicalensis Georgi could significantly reduce the expression of IL-6, TNF- $\alpha$, TLR3 and TRIF mRNA in the lung tissue of mice $(p<0.01)$ (Wang et al., 2014; Wang Y. F. et al., 2020). At the same time, studies have shown that gardenin and baicalin can also inhibit the TLR7/MyD88 pathway to reduce NF- $\kappa B$ activation $(p<0.05$ or $p<0.01)$ (Zhang and Yu, 2010; Wan et al., 2014). Yuhuan Xie et al. found that essential oil of Nepeta tenuifolia Benth. can inhibit TRAF6 protein expression in the lung tissue of mice, and have a certain inhibitory effect on MyD88 to achieve anti-influenza virus pneumonia $(p<0.05)$ (Xie Y. H. et al., 2007). Chinese medical formulas Sweet Wormwood and Scutellaria Gallbladder-Clearing Decoction (Haoqin Qingdan Tang), Pueraria Decoction (Gegen Tang), Wind-scatering and Lungdiffusing Formula Granule (Shufeng Xuanfei Fang Keli), Exterior-releasing and Interior-clearing Formula Granule (Jiebiao Qingli Fang Keli), and Lonicera, Forsythia, Bupleurum and Cinnamon Twig Formula II (Yinqiaochaigui Erhao Fang) all 
could inhibited expression of TLR7, MyD88, NF- $\kappa \mathrm{B}$ and decreased serum TNF- $\alpha$, IL-1 and IL-6 levels $(p<0.05$ or $p<0.01$ ) (Lai et al., 2011; Liu et al., 2014; Li et al., 2018; Geng et al., 2019).

\section{Regulation of the PI3K/Akt Signaling Pathway}

The PI3K/Akt signaling pathway can also activate the nuclear transcription factor NF- $\kappa \mathrm{B}$, which induces the expression of inflammatory factors (Harikrishnan et al., 2018). Studies have shown that resveratrol [from Morus alba L. (Sangshen), Reynoutria japonica Houtt. (Huzhang), Veratrum nigrum L. (Lilu) or Senna tora (L.) Roxb. (Juemingzi)] can inhibit the expression of PI3K and NF- $\kappa \mathrm{B}$ in the lung tissues of infected mice $(p<0.05)$ (Li M. et al., 2020). Xiaoxue Liu showed that polysaccharides and flavonoids from Morus alba L. could significantly reduce the expressions of PI3K, AKT1/2 and NF$\kappa \mathrm{Bp} 65$, as well as IL-4 and INF- $\gamma$ in serum of respiratory syncytial virus (RSV)-infected mice $(p<0.05)$ (Liu, 2016). Xiaoxue Liu et al. also pointed out that Lung-clearing and Collaterals-unblocking Ointment (Qingfei Tongluo Gao) applied on the back of mice could also inhibit the expression of $\mathrm{PI} 3 \mathrm{~K}$ and $\mathrm{NF}-\mathrm{\kappa B}$ proteins in lung tissue induced by respiratory syncytial virus, thereby reducing inflammation and protecting lung tissue $(p<0.05)$ (Liu X. X. et al., 2016). Shuling Nan et al. found that Ascending and Descending Powder (Shengjiang San) can reduce the excessive expression of NF- $\kappa \mathrm{B}$ protein in the lung tissue, significantly improve the content of lung sIgA, IL-10, ILIR $\alpha$ and sTNFR, reduce the serum IL- $1 \beta$, IL- 6 , TNF- $\alpha$ content, inhibit proinflammatory factor and induce suppression of inflammatory factor expression to reduce pulmonary inflammatory injury ( $p<0.05$ or $p<0.01$ ) (Nan et al., 2016a; Nan et al., 2016b). In addition, researchers found that hypericin and hyperoside extracted from Hypericum perforatum L. could reduce the expression of IL- 6 and TNF- $\alpha$ in lung tissue and serum of mice infected with influenza $A$ virus, and increase the expression of IFN- $\gamma$ and IL-10 protein $(p<0.05$ or $p<0.01)$ (Wang et al., 2009). Wei Luo et al. found that the levels of TNF- $\alpha$ and IL-10 in serum and lung tissues of mice infected with influenza virus were reduced by electroacupuncture and moxibustion at bilateral Feishu (BL 13) on the back of mice $(p<0.01)$ (Luo et al., 2014).

\section{Regulation of Lymphocyte Subsets}

As one of the three lines of defense, cellular immunity plays an important role in eliminating pathogens. Experimental studies have shown that Andrographis paniculata (Burm.f.) Nees and Ilex asprella (Hook. et Arn.) Champ. ex Benth. can increase the percentage of CD3+ lymphocytes in the T-lymphocyte subsets in peripheral blood of mice infected with influenza virus, and regulate the $\mathrm{CD} 4 / \mathrm{CD} 8$ ratio to enhance the immune function of mice (Chen et al., 2016; Wang et al., 2019). Hypericum perforatum L. extract can improve the immunologic function of influenza virus-infected mice by enhancing $\mathrm{T}$ and $\mathrm{B}$ lymphocyte conversion, phagocytic function of macrophages and NK killing activity $(p<0.05$ or $p<0.01$ ) (Xu et al., 2016). Gegen decoction can regulate the ratio of $\mathrm{CD} 3+\mathrm{CD} 4+/ \mathrm{CD} 3$
$+\mathrm{CD} 8+$ and CD4+IFN- $\gamma+/ \mathrm{CD} 4+\mathrm{IL}-4+$ in peripheral blood of virus-infected mice $(p<0.01)$ (Geng et al., 2019). Shengjiang Power can increase the percentage of $\mathrm{CD} 8+$ in peripheral blood, regulate the radio of $\mathrm{CD} 4+/ \mathrm{CD} 8+$, and improve the immune function of the body $(p<0.05$ or $p<0.01)$ (Nan et al., $2016 b)$. Other study results have shown that compared with ribavirin, the Haoqin Qingdan Decoction can improve the ratio of $\mathrm{T}$ lymphocyte subgroup and Th1/Th2 cell balance more effectively in rats with damp-heat syndrome of influenza viral pneumonia (Zhang et al., 2013).

\section{TCM Protecting Host Cells}

Some traditional Chinese medicines have been studied, which do not directly inhibit virus replication or regulate immune and inflammatory factors, but protect host cells and increase their tolerance to viruses. Shanshan Guo et al. found that the extract ZG from Gardenia jasminoides J. Ellis can improve the host cell membrane fluidity after infection of parainfluenza virus type 1 $(\mathrm{PIV}-1)(p<0.01)$ and maintain its normal function therefore to play an antiviral role (Guo et al., 2007).

\section{Clinical Research}

Compared with single herbs, traditional Chinese medical formulas are more widely used in the clinical prevention and treatment of viral pneumonia. Studies have shown that proprietary traditional Chinese medicine product or Chinese medical formula decoction plays a certain role in antiinflammatory, immune regulation, inhibition of viral replication, prevention of viral cytopathic disease and improvement of pathology (See Table 2).

\section{TCM for the Treatment of SARS Coronavirus Pneumonia}

Pneumonia caused by SARS coronavirus is a highly infectious pneumonia that can involve multiple organ lesions. The main clinical manifestations are fever, cough, headache, fatigue, aching pain of muscle and joint, oppression in chest, and dyspnea, etc. Tietao Deng, a master of Chinese medicine, considered that it belongs to the category of spring epidemic and damp-heat pestilence diseases, which pathogeneses are accumulation of damp-heat toxin, consumption of Qi and damage of Yin easily, and existance of blood stasis. According to Tietao Deng, SARS can be divided into early, middle, extreme and recovery stages (Deng, 2003). In the process of clinical treatment, therapeutic outcomes of combined treatment with TCM and western medicine are usually better than that of Western medicine alone in terms of release of clinical symptoms, improvements of pneumonia and blood oxygen saturation as well as the count of lymphocyte and T cell subsets. For example, Ruilin Zhang et al. treated 49 SARS patients with integrated traditional Chinese and western medicine. Beside the basic treatment, patients were respectively given Formula I for SARS during Hyperpyrexia Peroid (Feidian Gaoreqi Yihao Fang) with high fever to clear heat and resolve toxins, scatter wind and diffuse the lung, Formula II for SARS during Panting Peroid (Feidian Kechuanqi Erhao Fang) with cough and panting to clear heat 


\begin{tabular}{|c|c|c|c|c|c|c|c|c|c|}
\hline $\begin{array}{l}\text { Name of } \\
\text { Formulas }\end{array}$ & Ingredients & Efficacy & Usage Mode & $\begin{array}{c}\text { Model/Strains } \\
\text { (Registration number) }\end{array}$ & $\begin{array}{l}\text { Dosage/ } \\
\text { Duration }\end{array}$ & $\begin{array}{c}\mathrm{IC}_{50}, \mathrm{EC}_{50} \\
\mathrm{TCID}_{50}, \mathrm{TC}_{50} \\
\mathrm{TC}_{0}, \mathrm{LD}_{0} \\
\text { LD }_{50^{*}}\end{array}$ & Control & $\begin{array}{l}\text { Actions and } \\
\text { mechanisms }\end{array}$ & References \\
\hline $\begin{array}{l}\text { Ephedra } \\
\text { Decoction } \\
\text { (Mahuang } \\
\text { Tang) }\end{array}$ & $\begin{array}{l}\text { Ephedra sinica Stapf (Mahuang) 9g, } \\
\text { Cinnamomum cassia (L.) J. Presl (Guizhi) 6g, } \\
\text { Prunus armeniaca L. (Xingren) 6g and } \\
\text { Glycyrrhiza uralensis Fisch. ex DC. (Gancao) } \\
\text { 3g. }\end{array}$ & $\begin{array}{l}\text { Induce } \\
\text { sweating to } \\
\text { release the } \\
\text { exterior, } \\
\text { diffuse the } \\
\text { lung and } \\
\text { relieve } \\
\text { panting. }\end{array}$ & Decoction & $\begin{array}{l}\text { In vitro: influenza virus } \\
\text { A/PR/8/34 (H1N1) in } \\
\text { MDCK }\end{array}$ & $\begin{array}{l}5.0,2.5 \\
1.25,0.63 \\
0.31 \mathrm{~g} / \mathrm{L}\end{array}$ & $\begin{array}{l}1.59 \mathrm{~g} / \mathrm{L} \\
\left(\mathrm{EC}_{50}\right) ; 61.66 \\
\mathrm{~g} / \mathrm{L}\left(\mathrm{TC}_{50}\right) ; \\
5.66 \mathrm{~g} / \mathrm{L}\left(\mathrm{TC}_{0}\right)\end{array}$ & Oseltamivir & $\begin{array}{l}\text { Blocks the invasion of } \\
\text { influenza virus into host } \\
\text { cells, inhibits the } \\
\text { biosynthesis of influenza } \\
\text { virus in cells, and down- } \\
\text { regulates the expression } \\
\text { levels of TLR4, TLR7, } \\
\text { MyD88 and TRAF6 } \\
\text { mRNA in cells. }\end{array}$ & $\begin{array}{l}\text { Wei et al., } \\
2018\end{array}$ \\
\hline $\begin{array}{l}\text { Three } \\
\text { Substances } \\
\text { Scutellaria } \\
\text { Decoction } \\
\text { (Sanwu } \\
\text { Huangain Tang) }\end{array}$ & $\begin{array}{l}\text { Sophora flavescens Aiton (Kushen) 6g, } \\
\text { Scutellaria baicalensis Georgi (Huangqin) } 6 \mathrm{~g} \\
\text { and Rehmannia glutinosa (Gaertn.) DC. } \\
\text { (Gandihuang) 12g. }\end{array}$ & $\begin{array}{l}\text { Clear heat } \\
\text { and resolve } \\
\text { toxins, } \\
\text { nourish the } \\
\text { blood and } \\
\text { enrich yin. }\end{array}$ & $\begin{array}{l}\text { Extract by } \\
\text { water } \\
\text { extraction } \\
\text { and alcohol } \\
\text { sedimentation }\end{array}$ & $\begin{array}{l}\text { In vitro: influenza virus } \\
\text { A/PR/8/34 (H1N1) in } \\
\text { MDCK } \\
\text { In vivo: influenza virus } \\
\text { A/PR/8/34 (H1N1) in } \\
\text { mice }\end{array}$ & $\begin{array}{l}0.06,0.12 \\
0.24,0.49 \\
0.98,1.95 \\
\mathrm{mg} / \mathrm{ml} \\
5.85,11.70 \\
23.40 \mathrm{~g} / \mathrm{kg} / \\
\text { day }\end{array}$ & $\begin{array}{l}10^{-7} / 100 \mu l \\
\left(\mathrm{TCID}_{50}\right) ; \\
12.76 \mathrm{mg} / \mathrm{ml} \\
\left(\mathrm{TC}_{50}\right) ; 1.95 \\
\mathrm{mg} / \mathrm{ml}\left(\mathrm{TC}_{0}\right) \\
10^{-4.5} / 50 \mu \mathrm{ll} \\
\left(\mathrm{LD}_{50}\right)\end{array}$ & Oseltamivir & $\begin{array}{l}\text { Inhibits influenza A/PR/8/ } \\
34(\mathrm{H} 1 \mathrm{~N} 1) \text { virus at } \\
\text { different stages of viral } \\
\text { replication in vitro and in } \\
\text { vivo. }\end{array}$ & $\begin{array}{l}\text { Ma et al., } \\
2018\end{array}$ \\
\hline $\begin{array}{l}\text { Pueraria } \\
\text { Decoction } \\
\text { (Gegen Tang) }\end{array}$ & $\begin{array}{l}\text { Pueraria montana var. lobata (Willd.) Maesen \& } \\
\text { S.M.Almeida ex Sanjappa \& Predeep (Gegen) } \\
\text { 96g, Ephedra sinica Stapf (Mahuang) 72g, } \\
\text { Cinnamomum cassia (L.) J. Presl (Guizhi) 48g, } \\
\text { Paeonia lactiflora Pall. (Baishao) 48g, Zingiber } \\
\text { officinale Roscoe (Shengjiang) 72g, Ziziphus } \\
\text { jujuba Mill. (Dazao) 176g and Glycyrrhiza } \\
\text { uralensis Fisch. ex DC. (Gancao) 48g. }\end{array}$ & $\begin{array}{l}\text { Induce } \\
\text { sweating to } \\
\text { release the } \\
\text { exterior, } \\
\text { promote fluid } \\
\text { production } \\
\text { and unblock } \\
\text { the } \\
\text { channels. }\end{array}$ & $\begin{array}{l}\text { Water } \\
\text { extraction of } \\
\text { Pueraria } \\
\text { Decoction }\end{array}$ & $\begin{array}{l}\text { In vivo: influenza virus } \\
\text { (H1N1) in mice }\end{array}$ & $6.25 \mathrm{mg} / \mathrm{ml}$ & $\begin{array}{l}1 \times 10^{4.7} / 100 \mu \mathrm{l} \\
\left(\mathrm{TCID} \mathrm{D}_{50}\right) ; 1.81 \\
\mathrm{mg} / \mathrm{ml}\left(\mathrm{I} \mathrm{C}_{50}\right) ; \\
10.88 \mathrm{mg} / \mathrm{ml} \\
\left(\mathrm{TC} \mathrm{C}_{50}\right) ; 6.25 \\
\mathrm{mg} / \mathrm{ml}\left(\mathrm{TC} \mathrm{C}_{0}\right) \\
1 \times 10^{3.8} / 20 \mu \mathrm{l} \\
\left(\mathrm{LD}_{50}\right)\end{array}$ & Oseltamivir & $\begin{array}{l}\text { Antagonizes the activity } \\
\text { of } \mathrm{H} 1 \mathrm{~N} 1 \text { influenza virus, } \\
\text { inhibits virus adsorption, } \\
\text { restrain the expression of } \\
\text { pro-inflammatory factors } \\
\text { IL-1 } \alpha \text {, IL-6 and TNF- } \alpha \text {, } \\
\text { and downregulates TLR7 } \\
\text { expression. }\end{array}$ & $\begin{array}{l}\text { Geng et al., } \\
2019\end{array}$ \\
\hline $\begin{array}{l}\text { Heat-toxin- } \\
\text { clearing } \\
\text { Injection } \\
\text { (Reduning } \\
\text { Zhusheye) } \\
\text { (Patent } \\
\text { medicine) }\end{array}$ & $\begin{array}{l}\text { Artemisia annua L. (Qinghao), Lonicera } \\
\text { japonica Thunb. (Jinyinhua) and Gardenia } \\
\text { jasminoides J.Ellis (Zhizi). }\end{array}$ & $\begin{array}{l}\text { Clear heat, } \\
\text { scatter wind } \\
\text { and resolve } \\
\text { toxins. }\end{array}$ & $\begin{array}{l}\text { Preparation } \\
\text { solution of } \\
\text { injection }\end{array}$ & $\begin{array}{l}\text { In vitro: A/PR/8/34 } \\
\text { (H1N1) in MDCK } \\
\text { In vitro: A/Sydney/5/97 } \\
\text { (H3N2) in MDCK } \\
\text { In vitro: B/Jiangsu/10/ } \\
\text { 2003(B) in MDCK } \\
\text { Controlled study in } \\
\text { vivo: children with viral } \\
\text { pneumonia }\end{array}$ & $\begin{array}{l}0.5-0.6 \mathrm{ml} / \\
\text { (kg.day) }\end{array}$ & $\begin{array}{l}46.49 \pm 2.25 \\
\mu \mathrm{g} / \mathrm{ml}\left(\mathrm{I} \mathrm{C}_{50}\right) \\
49.77 \pm 1.77 \\
\mu \mathrm{g} / \mathrm{ml}\left(\mathrm{IC}_{50}\right) \\
45.33 \pm 5.32 \\
\mu \mathrm{g} / \mathrm{ml}\left(\mathrm{IC}_{50}\right) \\
\quad-\end{array}$ & Zanamivir & $\begin{array}{l}\text { Inhibits neuraminidase } \\
\text { activity of } \mathrm{H} 1 \mathrm{~N} 1, \mathrm{H} 3 \mathrm{~N} 2 \\
\text { and B influenza, relieves } \\
\text { symptoms such as } \\
\text { panting, cough and short } \\
\text { of breath, and decreases } \\
\text { body temperature. }\end{array}$ & $\begin{array}{l}\text { Sun et al., } \\
\text { 2014; Li, } \\
2013\end{array}$ \\
\hline $\begin{array}{l}\text { Wind-scatering } \\
\text { and Lung- } \\
\text { diffusing } \\
\text { Formula } \\
\text { Granule } \\
\text { (Shufeng } \\
\text { Xuanfei Fang } \\
\text { Keli) (Hospital } \\
\text { preparation) }\end{array}$ & $\begin{array}{l}\text { Lonicera japonica Thunb. (Jinyinhua), Forsythia } \\
\text { suspensa (Thunb.) Vahl (Lianqiao), Persicaria } \\
\text { tinctoria (Aiton) Spach (Daqingye), Arctium } \\
\text { lappa L. (Niubangzi), Isatis tinctoria L. } \\
\text { (Banlangen), Periostracum Cicadae (Chantui), } \\
\text { Fritillaria thunbergii Miq. (Zhebeimu), Scutellaria } \\
\text { baicalensis Georgi (Huangain), Nepeta } \\
\text { tenuifolia Benth. (Jingje), Glycine max (L.) Merr. } \\
\text { (Dandouchi), Imperata cylindrica (L.) P.Beauv. }\end{array}$ & $\begin{array}{l}\text { Clear heat } \\
\text { and resolve } \\
\text { toxins, and } \\
\text { vent the } \\
\text { exterior with } \\
\text { acrid-cool } \\
\text { (medicinals). }\end{array}$ & $\begin{array}{l}\text { Preparation } \\
\text { solution of } \\
\text { granule }\end{array}$ & $\begin{array}{l}\text { In vitro: influenza virus } \\
\text { A1/Qianfang/166/85 } \\
(\mathrm{H} 1 \mathrm{~N} 1) \text { in } \mathrm{A} 549\end{array}$ & $\begin{array}{l}10,5,2.5 \\
1.25,0.63 \\
\mu \mathrm{g} / \mathrm{ml}\end{array}$ & $\begin{array}{l}10^{-3.78} / 0.1 \mathrm{ml} \\
\left(\mathrm{TCID}_{50}\right) ; \\
10.20 \mu \mathrm{g} / \mathrm{ml} \\
\left(\mathrm{TC}_{0}\right) ; 38.56 \\
\mu \mathrm{g} / \mathrm{ml}\left(\mathrm{TC}_{50}\right) ; \\
2.36 \mu \mathrm{g} / \mathrm{ml} \\
\left(\mathrm{IC}_{50}\right) \\
\quad-\end{array}$ & Oseltamivir & $\begin{array}{l}\text { Reduces the mortality of } \\
\text { mice infected with virus } \\
\text { and prolong the average } \\
\text { survival time of mice, and } \\
\text { downregulates the } \\
\text { expression of TLR3, } \\
\text { TLR7, MyD88 and IL-6, } \\
\text { and increases the } \\
\text { expression of IL-4 and } \\
\text { IFN- } \gamma \text {. }\end{array}$ & $\begin{array}{l}\text { Liu et al., } \\
\text { 2014; Ge } \\
\text { et al., 2015; } \\
\text { Zhang et al., } \\
2015\end{array}$ \\
\hline
\end{tabular}




\section{Name of}

Formulas

Ingredients

Efficacy

Usage Mode

Model/Strains

Dosage/ IC $\mathrm{C}_{50}, \mathrm{EC}_{50}$,

Control

Actions and

References

(Registration number) Duration $\mathrm{TCID}_{50}, \mathrm{TC}_{50}$

$\mathrm{TC}_{0}, \mathrm{LD}_{0}$,

mechanisms

$\mathrm{LD}_{50}$ *

\begin{tabular}{|c|c|c|c|c|c|c|c|c|c|}
\hline & $\begin{array}{l}\text { (Baimaogen) and Glycyrrhiza uralensis Fisch. ex } \\
\text { DC. (Gancao). }\end{array}$ & & & & & & & & \\
\hline $\begin{array}{l}\text { Exterior- } \\
\text { releasing and } \\
\text { Interior-clearing } \\
\text { Formula } \\
\text { Granule } \\
\text { (Jiebiao Qingli } \\
\text { Fang Keli) } \\
\text { (Hospital } \\
\text { preparation) }\end{array}$ & $\begin{array}{l}\text { Ephedra sinica Stapf (Mahuang), Perilla } \\
\text { frutescens (L.) Britton (Zisuye), Nepeta tenuifolia } \\
\text { Benth. (Jingjie), Angelica biserrata (R.H.Shan \& } \\
\text { C.Q.Yuan) C.Q.Yuan \& R.H.Shan (Duhuo), } \\
\text { Hansenia forbesii (H.Boissieu) Pimenov \& } \\
\text { Kljuykov (Qianghuo), Gypsum Fibrosum } \\
\text { (Shigao), Artemisia annua L. (Qinghao), } \\
\text { Scutellaria baicalensis Georgi (Huangain), Aster } \\
\text { tataricus L.f. (Ziwan), Prunus armeniaca L. } \\
\text { (Xingren), Platycodon grandiflorus (Jacq.) A. } \\
\text { DC. (Jiegeng) and Glycyrrhiza uralensis Fisch. } \\
\text { ex DC. (Gancao). }\end{array}$ & $\begin{array}{l}\text { Release the } \\
\text { exterior and } \\
\text { clear the } \\
\text { interior. }\end{array}$ & $\begin{array}{l}\text { Granular } \\
\text { solution }\end{array}$ & $\begin{array}{l}\text { In vitro: influenza virus } \\
\text { A1/Qianfang/166/85 } \\
\text { (H1N1) in A549 }\end{array}$ & $\begin{array}{l}10,5,2.5 \\
1.25,0.63 \\
\mu \mathrm{g} / \mathrm{ml}\end{array}$ & $\begin{array}{l}10^{-3.78} / 0.1 \mathrm{ml} \\
\left(\mathrm{TCID}_{50}\right) ; 9.91 \\
\mu \mathrm{g} / \mathrm{ml}\left(\mathrm{TC}_{0}\right) ; \\
38.88 \mu \mathrm{g} / \mathrm{ml} \\
\left(\mathrm{TC}_{50}\right) ; 2.46 \\
\mu \mathrm{g} / \mathrm{ml}\left(\mathrm{IC}_{50}\right) \\
\quad-\end{array}$ & Oseltamivir & $\begin{array}{l}\text { Downregulates the } \\
\text { protein expression of } \\
\text { TLR7 and NF-kB, } \\
\text { prolongs the average } \\
\text { survival time of mice, } \\
\text { decreases the mRNA } \\
\text { and protein over- } \\
\text { expressions of IL-1, TNF- } \\
\alpha, \text { IL-6, MCP-1, reduces } \\
\text { inflammation, and } \\
\text { restores stability and } \\
\text { balance of immune } \\
\text { function. }\end{array}$ & $\begin{array}{l}\text { Liu et al., } \\
\text { 2014; Ge } \\
\text { et al., 2015; } \\
\text { Zhang et al., } \\
2015\end{array}$ \\
\hline $\begin{array}{l}\text { Lonicera, } \\
\text { Forsythia, } \\
\text { Bupleurum and } \\
\text { Cinnamon Twig } \\
\text { Granule } \\
\text { (Yinqiaochaigui } \\
\text { Keli) (Hospital } \\
\text { preparation) }\end{array}$ & $\begin{array}{l}\text { Lonicera japonica Thunb. (Jinyinhua), Forsythia } \\
\text { suspensa (Thunb.) Vahl (Lianqiao), Bupleurum } \\
\text { chinense DC. (Chaihu), Cinnamomum cassia } \\
\text { (L.) J.Presl (Guizhi), Platycodon grandiflorus } \\
\text { (Jacq.) A. DC. (Jiegeng), Paeonia lactiflora Pall. } \\
\text { (Baishao), Scutellaria baicalensis Georgi } \\
\text { (Huangain), Ephedra sinica Stapf (Mahuang), } \\
\text { Paris polyphylla var. chinensis (Franch.) H.Hara } \\
\text { (Chonglou) and Scrophularia ningpoensis } \\
\text { Hemsl. (Xuanshen). }\end{array}$ & $\begin{array}{l}\text { Harmonize } \\
\text { ying and wei } \\
\text { levels, } \\
\text { release the } \\
\text { exterior and } \\
\text { clear heat } \\
\text { toxin. }\end{array}$ & $\begin{array}{l}\text { Granular } \\
\text { solution } \\
\text { diluted in } \\
\text { DMEM }\end{array}$ & $\begin{array}{l}\text { In vitro: influenza virus } \\
\text { H1N1 (FM1) in MDCK } \\
\text { In vitro: influenza virus } \\
\text { H1N1 (PR8) in MDCK } \\
\text { In vitro: influenza virus } \\
\text { A III in MDCK }\end{array}$ & $\begin{array}{l}5,2.5,1.25 \\
0.625,0.312 \\
0.156,0.078 \\
0.039 \mathrm{mg} / \mathrm{ml}\end{array}$ & $\begin{array}{l}2.18 \mathrm{mg} / \mathrm{ml} \\
\left(\mathrm{TC}_{50}\right) ; 0.52 \\
\mathrm{mg} / \mathrm{ml}\left(\mathrm{IC}_{50}\right) \\
3.88 \mathrm{mg} / \mathrm{ml} \\
\left(\mathrm{TC}_{50}\right) ; 1.08 \\
\mathrm{mg} / \mathrm{ml}\left(\mathrm{I} \mathrm{I}_{50}\right) \\
3.39 \mathrm{mg} / \mathrm{ml} \\
\left(\mathrm{TC}_{50}\right) ;>5 \mathrm{mg} / \\
\mathrm{ml}\left(\mathrm{IC}_{50}\right)\end{array}$ & Ribavirin & $\begin{array}{l}\text { Decreases the content of } \\
\text { TNF- } \alpha \text {, IL- } 6 \text { in BALF, } \\
\text { increases the content of } \\
\text { SOD in lung } \\
\text { homogenate, decreases } \\
\text { the content of MDA, and } \\
\text { increases the ratio of T } \\
\text { lymphocyte subsets, and } \\
\text { inhibits TLR7-MyD88- } \\
\text { NF-KB signaling } \\
\text { pathway. }\end{array}$ & $\begin{array}{l}\text { Xu, 2014; Li } \\
\text { et al., 2018 }\end{array}$ \\
\hline $\begin{array}{l}\text { Sweet } \\
\text { Wormwood } \\
\text { and Scutellaria } \\
\text { Gallbladder- } \\
\text { Clearing } \\
\text { Decoction } \\
\text { (Haogin } \\
\text { Qingdan Tang) }\end{array}$ & $\begin{array}{l}\text { Artemisia annua L. (Qinghao) 6g, Scutellaria } \\
\text { baicalensis Georgi (Huangqin) 6g, Citrus } \\
\text { aurantium L. (Zhiqiao) 5g, Bambusa tuldoides } \\
\text { Munro (Zhuru) 9g, Citrus aurantium L. (Chenpi) } \\
5 \mathrm{~g} \text {, Pinellia ternata (Thunb.) Makino (Banxia) } \\
5 \mathrm{~g} \text {, Poria cocos (Schw.) Wolf (Fuling) 9g, } \\
\text { Talcum (Huashi) 6g, Glycyrrhiza uralensis Fisch. } \\
\text { ex DC. (Gancao) } 1 \mathrm{~g} \text { and Isatis tinctoria L. } \\
\text { (Qingdai) 2g. }\end{array}$ & $\begin{array}{l}\text { Clear } \\
\text { gallbladder } \\
\text { heat and } \\
\text { drain } \\
\text { dampness, } \\
\text { dissolve } \\
\text { phlegm and } \\
\text { harmonize } \\
\text { the stomach. }\end{array}$ & $\begin{array}{l}\text { Preparation } \\
\text { solution of } \\
\text { decoction }\end{array}$ & $\begin{array}{l}\text { In vitro: influenza virus } \\
\text { A1/Jingke 96-25, A3/ } \\
\text { Jingke 92-32, B/ } \\
\text { Jingfang 93-184 in } \\
\text { allantoic cavity of } \\
\text { chicken embryo } \\
\text { In vivo: influenza virus } \\
\text { (H1N1) in mice } \\
\text { Randomized controlled } \\
\text { study: patients with } \\
\text { influenza viral } \\
\text { pneumonia }\end{array}$ & $\begin{array}{l}36.92 \mathrm{mg} / \\
\text { (kg.day) } \\
0.18 \mathrm{~g} / \mathrm{ml} \text {, } \\
300 \mathrm{ml} / \text { day }\end{array}$ & 2 g/ml (LDo) & $\begin{array}{l}\text { Shuanghuanglian } \\
\text { Oral Liquid }\end{array}$ & $\begin{array}{l}\text { Inhibits influenza virus, } \\
\text { and improves lung index } \\
\text { and pathological } \\
\text { changes and reduces } \\
\text { the mRNA expression of } \\
\text { NF-kB. }\end{array}$ & $\begin{array}{l}\text { Mo et al., } \\
\text { 2005; Lai } \\
\text { et al., 2011; } \\
\text { Sang et al., } \\
2014\end{array}$ \\
\hline $\begin{array}{l}\text { Ascending and } \\
\text { Descending } \\
\text { Powder } \\
\text { (Shengjiang } \\
\text { San) }\end{array}$ & $\begin{array}{l}\text { Periostracum Cicadae (Chantui) 10g, Bombyx } \\
\text { Batryticatus (Jiangcan) } 10 \mathrm{~g}, \text { Rheum officinale } \\
\text { Baill. (Shengdahuang) } 6 \mathrm{~g} \text { and Curcuma longa } \\
\text { L. (Jianghuang) 9g. }\end{array}$ & $\begin{array}{l}\text { Clear heat } \\
\text { and resolve } \\
\text { toxins, } \\
\text { dissolve } \\
\text { phlegm and } \\
\text { dissipate } \\
\text { blood stasis. }\end{array}$ & Decoction & $\begin{array}{l}\text { In vivo: influenza virus } \\
\text { FM1 in mice }\end{array}$ & $4.55 \mathrm{~g} / \mathrm{kg}$ & $\begin{array}{l}10^{-3.5} / 100 \mu \mathrm{l} \\
\left(\mathrm{LD}_{50}\right)\end{array}$ & Ribavirin & $\begin{array}{l}\text { Inhibits ICAM-1 and NF- } \\
\kappa B \text { overexpression in } \\
\text { mouse lung, increases } \\
\text { SIgA secretion and the } \\
\text { expression of IL-10 and } \\
\text { IL-1R } \alpha \text {, and decreases }\end{array}$ & $\begin{array}{l}\text { Nan et al., } \\
2016 a ; \text { Nan } \\
\text { et al., } \\
2016 b\end{array}$ \\
\hline
\end{tabular}




\begin{tabular}{|c|c|c|c|c|c|c|c|c|c|}
\hline $\begin{array}{l}\text { Name of } \\
\text { Formulas }\end{array}$ & Ingredients & Efficacy & Usage Mode & $\begin{array}{c}\text { Model/Strains } \\
\text { (Registration number) }\end{array}$ & $\begin{array}{l}\text { Dosage/ } \\
\text { Duration }\end{array}$ & $\begin{array}{l}\mathrm{IC}_{50}, \mathrm{EC}_{50} \\
\mathrm{TCID}_{50}, \mathrm{TC}_{50} \\
\mathrm{TC}_{0}, \mathrm{LD}_{0} \\
\mathrm{LD}_{50}{ }^{*}\end{array}$ & Control & $\begin{array}{l}\text { Actions and } \\
\text { mechanisms }\end{array}$ & References \\
\hline $\begin{array}{l}\text { Wind-scattering } \\
\text { Toxins- } \\
\text { resolving } \\
\text { Capsule } \\
\text { (Shufeng Jiedu } \\
\text { Jiaonang) } \\
\text { (Patent } \\
\text { medicine) }\end{array}$ & $\begin{array}{l}\text { Reynoutria japonica Houtt. (Huzhang), } \\
\text { Forsythia suspensa (Thunb.) Vahl (Lianqiao), } \\
\text { Isatis tinctoria L. (Banlangen), Bupleurum } \\
\text { chinense DC. (Chaihu), Patrinia scabiosifolia } \\
\text { Link (Baijiangcao), Verbena officinalis L. } \\
\text { (Mabiancao), Phragmites australis subsp. } \\
\text { australis (Lugen) and Glycyrrhiza uralensis } \\
\text { Fisch. ex DC. (Gancao). }\end{array}$ & $\begin{array}{l}\text { Scatter wind } \\
\text { and clear } \\
\text { heat, resolve } \\
\text { toxins and } \\
\text { relieve sore } \\
\text { throat. }\end{array}$ & $\begin{array}{l}\text { Solution after } \\
\text { capsule } \\
\text { dissolution }\end{array}$ & $\begin{array}{l}\text { In vitro: influenza virus } \\
\text { H1N1 (FM1, PR8, } \\
\text { Jiangxixiushui, B10, } \\
\text { B59), RSV, } \\
\text { parainfluenza virus } \\
\text { (Xiantai) in A549 }\end{array}$ & $\begin{array}{l}5.55,2.94 \\
1.52,0.77 \mathrm{~g} / \\
\mathrm{L}\end{array}$ & 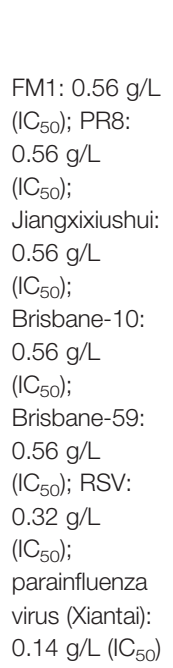 & Ribavirin & $\begin{array}{l}\text { content of IL-1 } 1 \beta, \text { IL-6, } \\
\text { and TNF- } \alpha \text {. } \\
\text { Inhibits the protein } \\
\text { expression of PGE2, } \\
\text { TNF- } \alpha \text {, IL- } 1 \alpha \text {, IL-1 } \beta \text {, and } \\
\text { IL-6, and restrains novel } \\
\text { coronavirus by inhibiting } \\
\text { MAPK/NF-KB signaling } \\
\text { pathway. }\end{array}$ & $\begin{array}{l}\text { Bao et al., } \\
\text { 2019; Qu X. } \\
\text { K. et al., } \\
2020\end{array}$ \\
\hline \multirow[t]{2}{*}{$\begin{array}{l}\text { Epidemic- } \\
\text { pathogen- } \\
\text { antagonizing } \\
\text { Beverage } \\
\text { (Kangli Yin) } \\
\text { (Hospital } \\
\text { preparation) }\end{array}$} & $\begin{array}{l}\text { Artemisia annua L. (Qinghao) 10g, Scutellaria } \\
\text { baicalensis Georgi (Huangqin) 15g, Pinellia } \\
\text { ternata (Thunb.) Makino (Banxia) 10g, } \\
\text { Periostracum Cicadae (Chantui) 6g, Bombyx } \\
\text { Batryticatus (Jiangcan) 10g, Citrus aurantium L. } \\
\text { (Chenpi) } 5 \mathrm{~g} \text {, Citrus aurantium L. (Zhishi) 10g, } \\
\text { Bambusa tuldoides Munro (Zhuru) 10g, Poria } \\
\text { cocos (Schw.) Wolf (Fuling) 20g, Curcuma } \\
\text { longa L. (Jianghuang) 10g, Pogostemon cablin } \\
\text { (Blanco) Benth. (Huoxiang) 10g, Rheum }\end{array}$ & $\begin{array}{l}\text { Clear heat } \\
\text { and drain } \\
\text { dampness, } \\
\text { harmonize } \\
\text { the stomach } \\
\text { and dissolve } \\
\text { phlegm. }\end{array}$ & $\begin{array}{l}\text { Decoction } \\
\text { solution } \\
\text { diluted in } \\
\text { DMEM }\end{array}$ & $\begin{array}{l}\text { In vitro: influenza virus } \\
\text { RSV Long in MRC-5 }\end{array}$ & $\begin{array}{l}22,11,5.5 \\
2.75,1.375 \\
0.6875 \\
0.344,0.172 \\
\mathrm{mg} / \mathrm{ml} \\
7.62,3.81 \\
1.905,0.953 \\
0.476,0.238 \\
0.119, \\
0.0595 \mathrm{mg} / \mathrm{ml}\end{array}$ & $\begin{array}{l}9.38 \mathrm{mg} / \mathrm{ml} \\
\left(T C_{0}\right) ; 21.33 \\
\mathrm{mg} / \mathrm{ml}\left(\mathrm{TC}_{50}\right) ; \\
>22 \mathrm{mg} / \mathrm{ml} \\
\left(\mathrm{IC}_{50}\right) \\
5.50 \mathrm{mg} / \mathrm{ml} \\
\left(\mathrm{TC}_{0}\right) ; 7.62 \\
\mathrm{mg} / \mathrm{ml}\left(\mathrm{TC} \mathrm{C}_{50}\right) ; \\
>7.62 \mathrm{mg} / \mathrm{ml} \\
\left(\mathrm{I}_{50}\right)\end{array}$ & Ribavirin & $\begin{array}{l}\text { No significant inhibitory } \\
\text { effect on influenza virus } \\
\text { H1N1 and RSV Long in } \\
\text { vitro. }\end{array}$ & $\begin{array}{l}\text { Deng, 2006; } \\
\text { Sun, } 2006\end{array}$ \\
\hline & $\begin{array}{l}\text { officinale Baill. (Dahuang) 5g, Houttuynia } \\
\text { cordata Thunb. (Yuxingcao) 15g, Eupatorium } \\
\text { fortunei Turcz. (Peilan) 10g and Glycyrrhiza } \\
\text { uralensis Fisch. ex DC. (Zhigancao) } 5 \mathrm{~g} \text {. }\end{array}$ & & $\begin{array}{l}\text { Decoction } \\
\text { solution }\end{array}$ & $\begin{array}{l}\text { In vivo: influenza virus } \\
\text { H1N1 (FM1) in mice }\end{array}$ & $\begin{array}{l}5 \mathrm{~g} / \mathrm{kg}, 2.5 \mathrm{~g} / \\
\mathrm{kg}\end{array}$ & - & & $\begin{array}{l}\text { Reduces lung tissue } \\
\text { lesions, increases the } \\
\text { levels of CD3+, CD4+, } \\
\text { IL-2 and IFN- } \gamma \text {, and } \\
\text { inhibits the excessive } \\
\text { production of CD8+, IL-6 } \\
\text { and TNF- } \alpha \text {. }\end{array}$ & \\
\hline $\begin{array}{l}\text { Two Roots } \\
\text { Lung-clearing } \\
\text { Beverage } \\
\text { (Ergen Qingfei } \\
\text { Yin) }\end{array}$ & $\begin{array}{l}\text { Imperata cylindrica (L.) P. Beauv. (Baimaogen) } \\
20 \mathrm{~g}, \text { Phragmites australis subsp. australis } \\
\text { (Lugen) 20g, Scutellaria baicalensis Georgi } \\
\text { (Huangqin) 10g, Gypsum Fibrosum } \\
\text { (Shengshigao) 30g, Prunus armeniaca L. } \\
\text { (Xingren) 10g, Ephedra sinica Stapf } \\
\text { (Zhimahuang) 6g, Anemarrhena asphodeloides } \\
\text { Bunge (Zhimu) 10g, Taraxacum mongolicum }\end{array}$ & $\begin{array}{l}\text { Clear heat } \\
\text { and dissolve } \\
\text { phlegm, } \\
\text { diffuse the } \\
\text { lung and } \\
\text { direct lung qi } \\
\text { downward. }\end{array}$ & Decoction & $\begin{array}{l}\text { Randomized controlled } \\
\text { study with random } \\
\text { number table: patients } \\
\text { with influenza A (H1N1) } \\
\text { viral pneumonia }\end{array}$ & $\begin{array}{l}0.923 \mathrm{~g} / \mathrm{ml}, \\
200 \mathrm{ml} / \text { day }\end{array}$ & - & Oseltamivir & $\begin{array}{l}\text { Relieves the symptoms } \\
\text { of cough, expectoration, } \\
\text { dry mouth, vexation, } \\
\text { fever, panting and } \\
\text { pulmonary rales, } \\
\text { increases the level of IL- } \\
10 \text { and decreases the } \\
\text { level of IL-6, IL-8, TNF- } \alpha\end{array}$ & $\begin{array}{l}\text { Tian et al., } \\
2019\end{array}$ \\
\hline
\end{tabular}

outt (Huzhang),

Capsu (Thunb) Vahl (Liangiao) australis (Lugen) and Glycyrrhiza uralensis Fisch. ex DC. (Gancao).

Artemisia annua L. (Qinghao) 10g, Scutellaria nd drain

In vitro: influenza virus 0.6875

$0.344,0.17$

(Kangli Y

he stomach

In vitro: influenza virus $\left(\mathrm{TC}_{0}\right) ; 7.62$ ( onga L (Jianghuang) 10g, Pogostemon cablin Benth. (Huoxiang) 10g, Rheum fortunei Turcz. (Peilan) $10 \mathrm{~g}$ and Glycyrrhiza (Zhimu) 10g, Taraxacum mongolicum 


\begin{tabular}{|c|c|c|c|c|c|c|c|c|c|}
\hline $\begin{array}{l}\text { Name of } \\
\text { Formulas }\end{array}$ & Ingredients & Efficacy & Usage Mode & $\begin{array}{c}\text { Model/Strains } \\
\text { (Registration number) }\end{array}$ & $\begin{array}{l}\text { Dosage/ } \\
\text { Duration }\end{array}$ & $\begin{array}{c}\mathrm{IC}_{50}, \mathrm{EC}_{50} \\
\mathrm{TCID}_{50}, \mathrm{TC}_{50} \\
\mathrm{TC}_{0}, \mathrm{LD}_{0} \\
\mathrm{LD}_{50}{ }^{*}\end{array}$ & Control & $\begin{array}{l}\text { Actions and } \\
\text { mechanisms }\end{array}$ & References \\
\hline
\end{tabular}

Hand.-Mazz. (Pugongying) 10g, Isatis tinctoria

L. (Banlangen) 15g, Morus alba L. (Sangbaipi)

and C-reactive protein in

10g, Houttuynia cordata Thunb. (Yuxingcao)

serum.

10g, Platycodon grandiflorus (Jacq) A. DC.

(Jiegeng) $10 \mathrm{~g}$ and Aster tataricus L.f. (Ziwan) $10 \mathrm{~g}$.

Sweet Dew Talcum (Huashi) 45g, Scutellaria baicalensis

Toxin- Georgi (Huangain) 30g, Artemisia capillaris

Removing Elixir Thunb. (Yinchen) 30g, Acorus calamus var.

(Ganlu Xiaodu angustatus Besser (Shichangpu) 18g, Fritillaria

Dan)

angustatus Besser (Shichangpu) 18g, Fritill
cirrhosa D.Don (Chuanbeimu) 15g, Akebia

trifoliata (Thunb.) Koidz. (Mutong)15g,

(Hogostemon cablin (Blanco) Benth. (Hung) and reso

12g, Forsythia suspensa (Thunb.) Vahl

(Lianqiao) 12g, Wurfbainia vera (Blackw.)

Skornick. \& A.D.Poulsen (Baidoukou) 12g,

Mentha canadensis L. (Bohe) $12 \mathrm{~g}$ and Iris

domestica (L.) Goldblatt \& Mabb. (Shegan) $12 \mathrm{~g}$

Folium Ginkgo Lepidium apetalum Willd. (Beitinglizi), Ephedra

and Ephedra sinica Stapf (Mahuang), Prunus armeniaca L.

Lung-clearing (Kuxingren), Fritillaria thunbergii Miq.

Capsule

(Zhebeimu), Eriobotrya japonica (Thunb.) Lind.

(Yinhuang

(Pipaye), Persicaria tinctoria (Aiton) Spach

Qingfei

(Paqingye), Acorus calamus var. angustatus

Besser (Shichangpu), Dioscorea nipponica

Drain

Decoction

In vivo: influenza virus

A/PR/8/34 (H1N1) in

mice

and remove

turbidity,

and resolve

Retrospective study:

patients with SARS

CoV-2 infection

Clear lung

heat and

Solution after In vivo: A/PR/8/34

dissolution

(Patent

Makino (Chuanshanlong), Aconitum

medicine) brachypodum Diels (Yizhihao), Ginkgo biloba L.

(Yinxingye), Schisandra chinensis (Turcz.) Baill.

(Wuweizi), Citrus aurantium L. (Zhishi), Gypsum

Fibrosum (Shengshigao) and Glycyrrhiza

uralensis Fisch. ex DC. (Gancao).

Ephedra,

Ephedra sinica Stapf (Mahuang) 6g, Prunus

Apricot Kernel, $\quad$ armeniaca L. (Xingren) 6g, Gypsum Fibrosum

Gypsum and (Shengshigao) 24g and Glycyrrhiza uralensis

Licorice

Fisch. ex DC. (Gancao) 6g.

Decoction

(Maxingshigan

Tang)

Lung-clearing Rheum officinale Baill. (Dahuang) and

and Collaterals- Scutellaria baicalensis Georgi (Huangqin) and

unblocking

Allium sativum L. (Dasuan).

Medicated

relieve cough serum

and calm

panting.

Release the Decoction

(H1N1) in MDCK

$50 \%, 25 \%$

$12.5 \%$

$6.25 \%$

$3.125 \%$

(serum

concentration)

In vitro: respiratory

$12.5 \%$,

Hep-2

exterior with

Decoction

acrid-cool

(medicinals)

clear lung

heat and

relieve

panting.

Clear heat

Paste

In vivo: respiratory

toxins.

$0.6 \mathrm{~g} /$ paste

(TCID

Long in rat

In vivo: respiratory

syncytial virus (RSV)

$6.25 \%$

$3.13 \%$

concentration) $0.1 \mathrm{~m}$

$1.87,2.8$,

$4.2,6.3 \mathrm{~g} / \mathrm{kg} \quad\left(E D_{50}\right)$

$\left(\mathrm{TC}_{0}\right)$
(H1N1) in rat

100, 200,

In vitro: $\mathrm{A} / \mathrm{PR} / 8 / 34$

$400 \mathrm{mg} / \mathrm{kg}$

containing

serum solution

$12.5 \%$ of the

containing

serum solution

serum solution
$\left(\mathrm{TC} \mathrm{C}_{0}\right) ; 10^{-8} \%$

Bairui Capsule

Inhibits neuraminidase

virus proliferation in vivo, et al., 2016;

improves pneumonia Qiu et al.,

symptoms and

histopathological

changes, and increases

the level of FGF2 and

protein expression of

FGFR1 in the lung.

2018

Inhibits neuraminidase Hsieh et al., activity and influenza 2012; Cui virus proliferation. et al., 2019

Reduces the scope of Liu X. X.

ung lesions and alveolar et al., 2016; exudates, and inhibits 
$\mathrm{LD}_{50}$ *

\section{Ointment}

(Qingfei

Tongluo Gao)

(Hospital

preparation)

Lung-clearing

Oral Liquid

(Qingfei

Koufuye)

Lonicera and

Forsythia

Epidemic-

Clearing

(Lianhua

Qingwen

Jiaonang)

(Patent

medicine)
Ephedra sinica Stapf (Mizhimahuang) 4g,

Prunus armeniaca L. (Kuxingren) 10g, Angelica lung and

decursiva (Miq.) Franch. \& Sav. (Qianhu) 10g, dissolve

Gypsum Fibrosum (Shengshigao) 24g, Morus phlegm,

alba L. (Mizhisangbaipi), Lepidium apetalum

Willd. (Tinglizi) $6 \mathrm{~g}$, Bistorta officinalis Delarbre

(Quanshen) 12g, Bombyx Batryticatus

(Baijiangcan) 6g, Reynoutria japonica Houtt.

(Huzhang) $12 \mathrm{~g}$ and Salvia miltiorrhiza Bunge (Danshen) 6g.

Forsythia suspensa (Thunb.) Vahl (Lianqiao), Lonicera japonica Thunb. (Jinyinhua), Ephedra sinica Stapf (Zhimahuang), Prunus armeniaca L. (Kuxingren), Gypsum Fibrosum

(Shengshigao), Isatis tinctoria L. (Banlangen),

Dryopteris crassirhizoma Nakai

Mianmaguanzhong), Houttuynia cordata

Thunb. (Yuxingcao), Pogostemon cablin

(Blanco) Benth. (Guanghuoxiang), Rheum

officinale Baill. (Dahuang), Rhodiola rosea L.

(Hongjingtian), menthol and Glycyrrhiza

uralensis Fisch. ex DC. (Gancao).

\begin{tabular}{|c|c|c|c|c|c|c|}
\hline $\begin{array}{l}\text { Medicated } \\
\text { serum }\end{array}$ & $\begin{array}{l}\text { In vitro: respiratory } \\
\text { syncytial virus (RSV) } \\
\text { Long or R6 in Hep-2 } \\
\text { In vivo: respiratory } \\
\text { syncytial virus (RSV) } \\
\text { Long in mice }\end{array}$ & $\begin{array}{l}20,10,5 \\
2.5,1.25 \\
0.625 \mathrm{mg} / \mathrm{ml} \\
4,1.33 \mathrm{mg} / \mathrm{ml}\end{array}$ & $\begin{array}{l}\text { Medicated } \\
\text { serum: 1:9 } \\
\left(\mathrm{TC}_{0}\right) ; 10^{-3.5} \\
50 \mu \mathrm{\mu l}\left(\mathrm{TCID}_{50}\right)\end{array}$ & Ribavirin & $\begin{array}{l}\text { Relieves the symptoms } \\
\text { of fever, cough and } \\
\text { panting, regulates the } \\
\text { Treg/Th17 balance, } \\
\text { increases IL-10 cytokines } \\
\text { and decreases IL-17 }\end{array}$ & $\begin{array}{l}\text { Wang et al., } \\
\text { 2008; Dong } \\
\text { et al., 2015; } \\
\text { Wang et al., } \\
2016\end{array}$ \\
\hline Oral liquid & $\begin{array}{l}\text { Randomized controlled } \\
\text { study: } 507 \text { cases of } \\
\text { children virus } \\
\text { pneumonia. }\end{array}$ & $\begin{array}{l}10,20,30 \\
\mathrm{ml} / \text { day, }(10 \mathrm{~g} / \\
\mathrm{ml})\end{array}$ & - & & $\begin{array}{l}\text { cytokines in RSV infected } \\
\text { mice. }\end{array}$ & \\
\hline \multirow[t]{3}{*}{$\begin{array}{l}\text { Solution after } \\
\text { capsule } \\
\text { dissolution }\end{array}$} & $\begin{array}{l}\text { In vitro: influenza virus } \\
\text { H1N1 (FM1, PR8, } \\
\text { Jiangxixiushui, B10, } \\
\text { B59), RSV, } \\
\text { parainfluenza virus } \\
\text { (Xiantai) in A549 }\end{array}$ & $\begin{array}{l}10,5.55, \\
2.94,1.52 \mathrm{~g} / \\
\mathrm{L}\end{array}$ & $\begin{array}{l}\text { FM1: } 1.12 \mathrm{~g} / \mathrm{L} \\
\left(\mathrm{I} \mathrm{C}_{50}\right) ; \mathrm{PR} 8: \\
1.12 \mathrm{~g} / \mathrm{L} \\
\left(\mathrm{I} \mathrm{C}_{50}\right) ; \\
\text { Jiangxixiushui: } \\
1.12 \mathrm{~g} / \mathrm{L} \\
\left(\mathrm{I} \mathrm{C}_{50}\right) ; \\
\text { Brisbane-10: } \\
1.12 \mathrm{~g} / \mathrm{L} \\
\left(\mathrm{I} \mathrm{C}_{50}\right) ; \\
\text { Brisbane-59: } \\
1.12 \mathrm{~g} / \mathrm{L} \\
\left(\mathrm{I} \mathrm{C}_{50}\right) ; \mathrm{RSV}: \\
0.50 \mathrm{~g} / \mathrm{L} \\
\left(\mathrm{I} \mathrm{C}_{50}\right) ; \text { Xiantai: } \\
0.28 \mathrm{~g} / \mathrm{L}\left(\mathrm{IC}_{50}\right)\end{array}$ & Ribavirin & $\begin{array}{l}\text { Inhibits the activity of } \\
\text { influenza virus H1N1, } \\
\text { parainfluenza virus, RSV, } \\
\text { MERS- CoV or SARS- } \\
\text { CoV in vitro as well as } \\
\text { influenza A virus (H1N1) } \\
\text { or MERS- CoV infection } \\
\text { in vivo, suppresses virus- } \\
\text { induced NF-kB } \\
\text { activation, alleviates } \\
\text { virus-induced gene } \\
\text { expression of IL-6, IL-8, } \\
\text { TNF-a, IP-10, and MCP- } \\
\text { 1, and also inhibits } \\
\text { SARS-CoV-2 replication } \\
\text { in Vero E6 cells and }\end{array}$ & $\begin{array}{l}\text { Zhu et al., } \\
\text { 2003; Ding } \\
\text { et al., 2017; } \\
\text { Guan et al., } \\
\text { 2018; Bao } \\
\text { et al., 2019; } \\
\text { Gao et al., } \\
\text { 2020; Li } \\
\text { R. F. et al., } \\
\text { 2020; Xiao } \\
\text { et al., } 2020\end{array}$ \\
\hline & $\begin{array}{l}\text { In vitro: Middle East } \\
\text { respiratory syndrome } \\
\text { coronavirus (MERS- } \\
\text { CoV) in Vero cells } \\
\text { In vitro: novel } \\
\text { coronavirus (SARS- } \\
\text { CoV-2) in Vero E6 cells }\end{array}$ & $\begin{array}{l}600,900 \\
1200,1500 \\
1800,2100 \\
2500 \mu \mathrm{g} / \mathrm{ml} \\
150,300 \\
600 \mu \mathrm{g} / \mathrm{ml}\end{array}$ & $\begin{array}{l}8472 \mu \mathrm{g} / \mathrm{ml} \\
\left(\mathrm{IC}_{50}\right)\end{array}$ & Remdesivir & $\begin{array}{l}\text { markedly reduced pro- } \\
\text { inflammatory cytokines } \\
\text { (TNF- } \alpha, \text { L- L- }, \text { CCL-2/ } \\
\text { MCP-1 and CXCL-10/IP- } \\
\text { 10) production at the } \\
\text { mRNA levels. }\end{array}$ & \\
\hline & $\begin{array}{l}\text { Randomized controlled } \\
\text { study: patients with } \\
\text { COVID-19.(Registration } \\
\text { number of clinical trials: } \\
\text { ChiCTR2000029601). }\end{array}$ & $0.3 \mathrm{~g} / \mathrm{kg}$ & - & $\begin{array}{l}\text { Oseltamivir and } \\
\text { arbidol }\end{array}$ & $\begin{array}{l}\text { Relieves clinical } \\
\text { symptoms, reduces } \\
\text { utilization rate of anti- } \\
\text { infective drugs, and } \\
\text { improves patient } \\
\text { prognosis. }\end{array}$ & \\
\hline
\end{tabular}


Name of

Formulas

Ingredients

Efficacy

Usage Mode

Model/Strains

Dosage/

$\mathrm{IC}_{50}, \mathrm{EC}_{50}$

Control

Actions and

mechanisms

(Registration number) Duration $\mathrm{TCID}_{50}, \mathrm{TC}_{50}$

$\mathrm{TC}_{0}, \mathrm{LD}_{0}$

$\mathrm{LD}_{50}$ *

Formula I for Ephedra sinica Stapf (Mahuang) 5g, Prunus

SARS During

armeniaca L. (Xingren) 12g, Gypsum Fibrosum

Clear heat

Decoction

study: patients with

$0.593 \mathrm{~g} / \mathrm{ml}$

toxins,

Shengshigao) 45g, Anemarrhena

Peroid (Feidian asphodeloides Bunge (Zhimu) 10g, Lonicera

Gaoreqi Yihao japonica Thunb. (Jinyinhua) $15 \mathrm{~g}$, Forsythia

Fang)

suspensa (Thunb.) Vahl (Lianqiao) 12g,

scatter wind

and diffuse

Gardenia jasminoides J.Ellis (Zhizi) 12g,

Scutellaria baicalensis Georgi (Huangqin) 12g,

Perilla frutescens (L.) Britton (Zisuye) 10g,

Artemisia capillaris Thunb. (Yinchen) 15g,

Pueraria montana var. lobata (Willd.) Maesen \&

S.M.Almeida ex Sanjappa \& Predeep (Gegen)

$15 \mathrm{~g}$ and Pseudostellaria heterophylla (Miq.) Pax

(Taizishen) 15g.

Formula II for Panax quinquefolius L. (Xiyangshen) $15 \mathrm{~g}$,

SARS During Ophiopogon japonicus (Thunb.) Ker Gawl.

Panting Peroid (Maidong) 10g, Schisandra chinensis (Turcz.)

(Feidian

Baill. (Wuweizi) 10g, Cornus officinalis Siebold

Kechuanqi

Erhao Fang)

\& Zucc. (Shanzhuyu) 12g, Lepidium apetalum

Willd. (Tinglizi) $15 \mathrm{~g}$, Aster tataricus L.f. (Ziwan)

$15 \mathrm{~g}$, Eriobotrya japonica (Thunb.) Lindl.

(Pipaye) 12g, Pheretima (Dilong) 12g, Salvia

miltiorrhiza Bunge (Danshen) 12g, Paeonia

anomala subsp. veitchii (Lynch) D.Y.Hong \&

K.Y.Pan (Chishao) 12g, Trollius chinensis

Bunge (Jinlianhua) 8g, Scutellaria baicalensis

Georgi (Huangqin) $10 \mathrm{~g}$ and Trichosanthes

kirilowii Maxim. (Gualoupi) 15g.

Formula III for Pseudostellaria heterophylla (Miq) Pax

SARS During (Taizishen) $15 \mathrm{~g}$, Ophiopogon japonicus

Convalescence (Thunb.) Ker Gawl. (Maidong) 15g, Atractylodes

(Feidian Huifuqi macrocephala Koidz. (Baizhu) 15g, Eriobotrya

Sanhao Fang) japonica (Thunb.) Lindl. (Zhipipaye) 15g,

Wurfbainia villosa var. xanthioides (Wall. ex

Baker) Skornick. \& A.D.Poulsen (Sharen) 6g,

Hordeum vulgare L. (Jiaomaiya) $15 \mathrm{~g}$,

Crataegus pinnatifida Bunge (Jiaoshanzha)

$15 \mathrm{~g}$, Astragalus mongholicus Bunge

(Shenghuangqi) $15 \mathrm{~g}$. Pueraria montana var.

lobata (Willd.) Maesen \& S.M.Almeida ex

Sanjappa \& Predeep (Gegen) 15g, Salvia

miltiorrhiza Bunge (Danshen) $15 \mathrm{~g}$, Citrus

aurantium L. (Chenpi) $6 \mathrm{~g}$ and Polygonatum

cyrtonema Hua (Huangjing) 15g.

\section{Clear}

invigorate

blood, boost

qi and

nourish yin,

relieve cough

and calm

panting.

\section{Boost qi and Decoction} nourish yin

ortify the

harmonize

the stomach.

Decoction

severe acute

respiratory syndrome

(SARS)

Parallel controlled

study: patients with

severe acute

respiratory syndrome

(SARS)

Parallel controlled

study: patients with

$0.59 \mathrm{~g} / \mathrm{ml}$

severe acute

respiratory syndrome

(SARS)
$0.527 \mathrm{~g} / \mathrm{ml}$,

$300 \mathrm{ml} /$ day

$300 \mathrm{ml} /$ day

(n)

Promotes the recovery of Zhang $R$.

immune function and et al., 2003

improves the lung

inflammatory damage,

improves clinical

symptoms, reduces

hormone dosage and

shortens the course of

treatment.

number of white blood

Zhang R. L. absolute value and the

time of absorption of

patchy shadow on chest x-ray 


\begin{tabular}{|c|c|c|c|c|c|c|c|c|c|}
\hline $\begin{array}{l}\text { Name of } \\
\text { Formulas }\end{array}$ & Ingredients & Efficacy & Usage Mode & $\begin{array}{c}\text { Model/Strains } \\
\text { (Registration number) }\end{array}$ & $\begin{array}{l}\text { Dosage/ } \\
\text { Duration }\end{array}$ & $\begin{array}{c}\mathrm{IC}_{50}, \mathrm{EC}_{50} \\
\mathrm{TCID}_{50}, \mathrm{TC}_{50} \\
\mathrm{TC}_{0}, \mathrm{LD}_{0} \\
\mathrm{LD}_{50}{ }^{*}\end{array}$ & Control & $\begin{array}{l}\text { Actions and } \\
\text { mechanisms }\end{array}$ & References \\
\hline $\begin{array}{l}\text { SARS-Formula- } \\
\text { I (Feidian Yihao } \\
\text { Fang) }\end{array}$ & $\begin{array}{l}\text { Gypsum Fibrosum (Shengshigao) 45g, } \\
\text { Bupleurum chinense DC. (Chaihu) 15g, } \\
\text { Anemarrhena asphodeloides Bunge (Zhimu) } \\
10 \mathrm{~g} \text {, Fritillaria thunbergii Miq. (Zhebeimu) 10g, } \\
\text { Scutellaria baicalensis Georgi (Huangain) 15g, } \\
\text { Artemisia annua L. (Qinghao) 15g, Paeonia } \\
\text { suffruticosa Andrews (Mudanpi) 10g, Paeonia } \\
\text { anomala subsp. veitchii (Lynch) D.Y.Hong \& } \\
\text { K.Y.Pan (Chishao) 12g, Forsythia suspensa } \\
\text { (Thunb.) Vahl (Lianqiao) 15g, Cornus officinalis } \\
\text { Siebold \& Zucc. (Shanzhuyu) 30g, Atractylodes } \\
\text { lancea (Thunb.) DC. (Cangzhu) 15g, } \\
\text { Pogostemon cablin (Blanco) Benth. (Huoxiang) } \\
\text { 15g, Coix lacryma-jobi var. ma-yuen } \\
\text { (Rom.Caill.) Stapf (Yiyiren) 15g and Prunus } \\
\text { armeniaca L. (Chaoxingren) 10g. }\end{array}$ & $\begin{array}{l}\text { Clear heat } \\
\text { and resolve } \\
\text { toxins, dispel } \\
\text { dampness } \\
\text { and remove } \\
\text { turbidity. }\end{array}$ & Decoction & $\begin{array}{l}\text { Simple stratified } \\
\text { randomized controlled } \\
\text { study: patients with } \\
\text { severe acute } \\
\text { respiratory syndrome } \\
\text { (SARS) in the early mild } \\
\text { stage. } \\
\text { Prospective study: } \\
\text { patients with severe } \\
\text { acute respiratory } \\
\text { syndrome (SARS) in } \\
\text { the mild or severe } \\
\text { stage. }\end{array}$ & $\begin{array}{l}0.58 \mathrm{~g} / \mathrm{ml} \text {, } \\
400 \mathrm{ml} / \text { day }\end{array}$ & - & $\begin{array}{l}\text { Glucocorticoid, } \\
\text { ganciclovir, } \\
\text { levofloxacin, } \\
\text { Rocephin, } \\
\text { Sulperazon, and } \\
\text { thymosin }\end{array}$ & $\begin{array}{l}\text { Shortens the time of } \\
\text { fever, slows down the } \\
\text { symptoms of systemic } \\
\text { poisoning caused by } \\
\text { fever, promotes the } \\
\text { absorption of pulmonary } \\
\text { inflammation, and } \\
\text { accelerates the reduction } \\
\text { of glucocorticoid. }\end{array}$ & $\begin{array}{l}\text { Zhang Y. L. } \\
\text { et al., 2003; } \\
\text { Zhang X. M. } \\
\text { et al., } 2003\end{array}$ \\
\hline $\begin{array}{l}\text { SARS-Formula- } \\
\text { II (Feidian Erhao } \\
\text { Fang) }\end{array}$ & $\begin{array}{l}\text { Scutellaria baicalensis Georgi (Huangain) 15g, } \\
\text { Artemisia annua L. (Qinghao) 15g, } \\
\text { Trichosanthes kirilowii Maxim. (Gualou) 30g, } \\
\text { Salvia miltiorrhiza Bunge (Danshen) 15g, Inula } \\
\text { japonica Thunb. (Xuanfuhua) 10g, Curcuma } \\
\text { aromatica Salisb. (Yujin) 10g, Acorus calamus } \\
\text { var. angustatus Besser (Shichangpu) 10g, } \\
\text { Dioscorea collettii var. hypoglauca (Palib.) } \\
\text { S.J.Pei \& C.T.Ting (Bixie) 12g, Faeces } \\
\text { Bombycis (Cansha) 15g, Atractylodes lancea } \\
\text { (Thunb.) DC. (Cangzhu) 15g, Atractylodes } \\
\text { macrocephala Koidz. (Baizhu) 15g, Polyporus } \\
\text { umbellatus (Pers.) Fries (Zhuling) 15g, Poria } \\
\text { cocos (Schw.) Wolf (Fuling) 15g, Coix lacryma- } \\
\text { jobi var. ma-yuen (Rom.Caill.) Stapf (Yiyiren) } \\
\text { 15g, Prunus armeniaca L. (Chaoxingren) 10g, } \\
\text { Plantago asiatica L. (Cheqianzi) 10g and } \\
\text { Cornus officinalis Siebold \& Zucc. (Shanzhuyu) } \\
\text { 30g. }\end{array}$ & $\begin{array}{l}\text { Clear and } \\
\text { dispel damp- } \\
\text { heat, diffuse } \\
\text { the lung and } \\
\text { direct } \\
\text { counterflow } \\
\text { downward. }\end{array}$ & Decoction & $\begin{array}{l}\text { Simple stratified } \\
\text { randomized controlled } \\
\text { study: patients with } \\
\text { severe acute } \\
\text { respiratory syndrome } \\
\text { (SARS) in the early mild } \\
\text { stage. } \\
\text { Prospective study: } \\
\text { patients with severe } \\
\text { acute respiratory } \\
\text { syndrome (SARS) in } \\
\text { the mild or severe } \\
\text { stage. }\end{array}$ & $\begin{array}{l}0.757 \mathrm{~g} / \mathrm{ml}, \\
300 \mathrm{ml} / \text { day }\end{array}$ & - & $\begin{array}{l}\text { Glucocorticoid, } \\
\text { ganciclovir, } \\
\text { levofloxacin, } \\
\text { Rocephin, } \\
\text { Sulperazon, and } \\
\text { thymosin }\end{array}$ & $\begin{array}{l}\text { Shortens the average } \\
\text { fever time, alleviates the } \\
\text { systemic symptoms } \\
\text { caused by fever, } \\
\text { promotes the absorption } \\
\text { of lung inflammation and } \\
\text { accelerates the reduction } \\
\text { of glucocorticoid. }\end{array}$ & $\begin{array}{l}\text { Zhang Y. L. } \\
\text { et al., 2003; } \\
\text { Zhang X. M. } \\
\text { et al., } 2003\end{array}$ \\
\hline $\begin{array}{l}\text { SARS-Formula- } \\
\text { III (Feidian } \\
\text { Sanhao Fang) }\end{array}$ & $\begin{array}{l}\text { Panax quinquefolius L. (Xiyangshen) 30g, } \\
\text { Astragalus mongholicus Bunge (Shenghuangqi) } \\
30 \mathrm{~g} \text {, Cornus officinalis Siebold \& Zucc. } \\
\text { (Shanzhuyu) } 30 \mathrm{~g} \text {, Ophiopogon japonicus } \\
\text { (Thunb.) Ker Gawl. (Maidong) } 15 \mathrm{~g}, \\
\text { Anemarrhena asphodeloides Bunge (Zhimu) } \\
\text { 10g, Fritillaria thunbergii Miq. (Zhebeimu) 10g, } \\
\text { Patrinia scabiosifolia Link (Baijiangcao) 30g, } \\
\text { Forsythia suspensa (Thunb.) Vahl (Lianqiao) } \\
\text { 15g, Salvia miltiorrhiza Bunge (Danshen) 15g, }\end{array}$ & $\begin{array}{l}\text { Boost qi and } \\
\text { nourish yin, } \\
\text { dissolve } \\
\text { phlegm and } \\
\text { invigorate } \\
\text { blood, drain } \\
\text { dampness } \\
\text { and direct } \\
\text { turbidity } \\
\text { downward. }\end{array}$ & Decoction & $\begin{array}{l}\text { Simple stratified } \\
\text { randomized controlled } \\
\text { study: patients with } \\
\text { severe acute } \\
\text { respiratory syndrome } \\
\text { (SARS) in the early mild } \\
\text { stage. } \\
\text { Prospective study: } \\
\text { patients with severe } \\
\text { acute respiratory }\end{array}$ & $\begin{array}{l}0.923 \mathrm{~g} / \mathrm{ml} \text {, } \\
300 \mathrm{ml} / \text { day }\end{array}$ & - & $\begin{array}{l}\text { Glucocorticoid, } \\
\text { antibiotics, } \\
\text { thymosin, and } \\
\text { gamma globulin }\end{array}$ & $\begin{array}{l}\text { Shortens the average } \\
\text { fever time, alleviates the } \\
\text { systemic symptoms } \\
\text { caused by fever, } \\
\text { promotes the absorption } \\
\text { of lung inflammation and } \\
\text { accelerates the reduction } \\
\text { of glucocorticoid. }\end{array}$ & $\begin{array}{l}\text { Zhang Y. L. } \\
\text { et al., 2003; } \\
\text { Zhang X. M. } \\
\text { et al., } 2003\end{array}$ \\
\hline
\end{tabular}




\begin{tabular}{|c|c|c|c|c|c|c|c|c|c|}
\hline $\begin{array}{l}\text { Name of } \\
\text { Formulas }\end{array}$ & Ingredients & Efficacy & Usage Mode & $\begin{array}{c}\text { Model/Strains } \\
\text { (Registration number) }\end{array}$ & $\begin{array}{l}\text { Dosage/ } \\
\text { Duration }\end{array}$ & $\begin{array}{l}\mathrm{IC}_{50}, \mathrm{EC}_{50} \\
\mathrm{TCID}_{50}, \mathrm{TC}_{50} \\
\mathrm{TC}_{0}, \mathrm{LD}_{0} \\
\mathrm{LD}_{50}\end{array}$ & Control & $\begin{array}{l}\text { Actions and } \\
\text { mechanisms }\end{array}$ & References \\
\hline & $\begin{array}{l}\text { Dioscorea collettii var. hypoglauca (Palib.) } \\
\text { S.J.Pei \& C.T.Ting (Bixie) 12g, Faeces } \\
\text { Bombycis (Cansha) 15g, Coix lacryma-jobi var. } \\
\text { ma-yuen (Rom.Caill.) Stapf (Yiyiren) 15g, } \\
\text { Polyporus umbellatus (Pers.) Fries (Zhuling) } \\
\text { 15g, Poria cocos (Schw.) Wolf (Fuling) 15g, } \\
\text { Trichosanthes kirilowii Maxim. (Gualou) } 30 \mathrm{~g} \\
\text { and Aster tataricus L.f. (Ziwan) 15g. }\end{array}$ & & & $\begin{array}{l}\text { syndrome (SARS) in } \\
\text { the mild or severe } \\
\text { stage. }\end{array}$ & & & $\begin{array}{l}\text { Rocephin, } \\
\text { Sulperazon, and } \\
\text { thymosin }\end{array}$ & & \\
\hline $\begin{array}{l}\text { Compound } \\
\text { Forsythia and } \\
\text { Taraxaci } \\
\text { Granule (Fufang } \\
\text { Lianpu Keli) } \\
\text { (Patent } \\
\text { medicine) }\end{array}$ & $\begin{array}{l}\text { Forsythia suspensa (Thunb.) Vahl (Lianqiao), } \\
\text { Taraxacum mongolicum Hand.-Mazz. } \\
\text { (Pugongying), Lonicera japonica Thunb. } \\
\text { (Jinyinhua), Scutellaria baicalensis Georgi } \\
\text { (Huangqin) and Isatis tinctoria L. (Banlangen). }\end{array}$ & $\begin{array}{l}\text { Release the } \\
\text { exterior with } \\
\text { acrid-cool } \\
\text { (medicinals), } \\
\text { clear heat } \\
\text { and resolve } \\
\text { toxins. }\end{array}$ & $\begin{array}{l}\text { Water } \\
\text { solution }\end{array}$ & $\begin{array}{l}\text { In vitro: novel } \\
\text { coronavirus (SARS- } \\
\text { CoV) BJ01 in Vero E6 } \\
\text { cells }\end{array}$ & 56 mg/ml & $\begin{array}{l}0.49 \mathrm{mg} / \mathrm{ml} \\
\left(\mathrm{EC}_{50}\right)\end{array}$ & Ribavirin & $\begin{array}{l}\text { Inhibits SARS-CoV } \\
\text { cultured in Vero-E6 cells. }\end{array}$ & $\begin{array}{l}\text { Zhu et al., } \\
2003\end{array}$ \\
\hline $\begin{array}{l}\text { Six Spirits } \\
\text { Capsule } \\
\text { (Liushen } \\
\text { Jiaonang) } \\
\text { (Patent } \\
\text { medicine) }\end{array}$ & $\begin{array}{l}\text { Calculus Bovis (Niuhuang), Moschus } \\
\text { (Shexiang), Borneolum Syntheticum (Bingpian), } \\
\text { Venenum Bufonis (Chansu), Margarita } \\
\text { (Zhenzhu) and Realgar (Xionghuang). }\end{array}$ & $\begin{array}{l}\text { Clear heat } \\
\text { and resolve } \\
\text { toxins, } \\
\text { reduce } \\
\text { inflammation } \\
\text { and relieve } \\
\text { pain. }\end{array}$ & $\begin{array}{l}\text { Triturated } \\
\text { and prepared } \\
\text { in dimethyl } \\
\text { sulfoxide } \\
\text { (DMSO) }\end{array}$ & $\begin{array}{l}\text { In vitro: SARS-CoV-2 } \\
\text { (MT123290.1) in Vero } \\
\text { E6 cells }\end{array}$ & $\begin{array}{l}2.00,1.00 \\
0.50,0.25 \\
\mu \mathrm{g} / \mathrm{ml}\end{array}$ & $\begin{array}{l}0.6024 \mu \mathrm{g} / \mathrm{ml} \\
\left(\mathrm{IC}_{50}\right) ; 4.930 \\
\mu \mathrm{g} / \mathrm{ml}\left(\mathrm{TC}_{50}\right) ; \\
10^{-6} / 100 \mu \mathrm{l} \\
\left(\mathrm{TCI}_{50}\right)\end{array}$ & Remdesivir & $\begin{array}{l}\text { Inhibits SARS-CoV-2 } \\
\text { virus infection via } \\
\text { downregulating the } \\
\text { expression of } \\
\text { inflammatory cytokines } \\
\text { induced virus and } \\
\text { regulating the activity of } \\
\text { NF-kB/MAPK signaling } \\
\text { pathway in vitro. }\end{array}$ & $\begin{array}{l}\text { Ma et al., } \\
2020\end{array}$ \\
\hline $\begin{array}{l}\text { Lung-clearing } \\
\text { and Toxin- } \\
\text { expelling } \\
\text { Decoction } \\
\text { (Qingfei Paidu } \\
\text { Tang) }\end{array}$ & $\begin{array}{l}\text { Ephedra sinica Stapf (Mahuang) 9g, Glycyrrhiza } \\
\text { uralensis Fisch. ex DC. (Zhigancao) 6g, Prunus } \\
\text { armeniaca L. (Xingren), Gypsum Fibrosum } \\
\text { (Shengshigao) } 10 \mathrm{~g} \text { (30g for fever), } \\
\text { Cinnamomum cassia (L.) J.Presl (Guizhi) 9g, } \\
\text { Alisma plantago-aquatica subsp. orientale } \\
\text { (Sam.) Sam. (Zexie) 9g, Polyporus umbellatus } \\
\text { (Pers.) Fries (Zhuling) 9g, Atractylodes } \\
\text { macrocephala Koidz. (Baizhu) 9g, Poria cocos } \\
\text { (Schw.) Wolf (Fuling) 15g, Bupleurum chinense } \\
\text { DC. (Chaihu) 16g, Scutellaria baicalensis } \\
\text { Georgi (Huangqin) 6g, Pinellia ternata (Thunb.) } \\
\text { Makino (Jiangbanxia)9g, Aster tataricus L.f. } \\
\text { (Ziwan) 9g, Zingiber officinale Roscoe } \\
\text { (Shengjiang) 9g, Tussilago farfara L. } \\
\text { (Kuandonghua) 9g, Iris domestica (L.) Goldblatt } \\
\text { \& Mabb. (Shegan) 9g, Asarum sieboldii Miq. } \\
\text { (Xixin) 6g, Dioscorea oppositifolia L. (Shanyao) } \\
\text { 12g, Citrus aurantium L. (Zhishi) 6g, Citrus } \\
\text { aurantium L. (Chenpi) 6g and Pogostemon } \\
\text { cablin (Blanco) Benth. (Huoxiang) 9g. }\end{array}$ & $\begin{array}{l}\text { Dredge the } \\
\text { sanjiao, clear } \\
\text { lung heat } \\
\text { and expel } \\
\text { toxins, calm } \\
\text { panting and } \\
\text { relieve } \\
\text { cough. }\end{array}$ & Decoction & $\begin{array}{l}\text { Comparison before and } \\
\text { after treatment: } \\
\text { patients with COVID- } \\
19 . \\
\text { Clinical retrospective } \\
\text { controlled study: } \\
\text { patients with COVID- } \\
\text { 19.(Registration } \\
\text { number of clinical trials: } \\
\text { ChiCTR2000029778 } \\
\text { and registration } \\
\text { number of TCM clinical } \\
\text { trial registry: } \\
\text { ChiMCTR2000003003). }\end{array}$ & $\begin{array}{l}0.985 \mathrm{or} \\
1.085 \mathrm{~g} / \mathrm{ml} \\
200 \mathrm{ml} / \text { day } \\
\\
0.4925 \mathrm{or} \\
0.5425 \mathrm{~g} / \mathrm{ml} \\
400 \mathrm{ml} / \text { day }\end{array}$ & $\begin{array}{l}>1,600 \mathrm{mg} / \mathrm{kg} \\
(\text { LD50) }\end{array}$ & $\begin{array}{l}\quad- \\
\text { Interferon, } \\
\text { lopinavir, or } \\
\text { arbidol }\end{array}$ & $\begin{array}{l}\text { Relieves cough, nasal } \\
\text { congestion, runny nose, } \\
\text { fatigue, anorexia, sore } \\
\text { throat, diarrhea and } \\
\text { other symptoms, and } \\
\text { shows anti-inflammatory } \\
\text { effects compared with } \\
\text { those of only Western } \\
\text { medicine in patients with } \\
\text { mild and moderate } \\
\text { COVID-19, and tends to } \\
\text { mitigate the extent of } \\
\text { multi-organ impairment. }\end{array}$ & $\begin{array}{l}\text { Chen J. } \\
\text { et al., 2020; } \\
\text { Wang R. Q. } \\
\text { et al., 2020; } \\
\text { Xin et al., } \\
\text { 2020; Zhou } \\
\text { et al., } 2020\end{array}$ \\
\hline
\end{tabular}




\begin{tabular}{|c|c|c|c|c|c|c|c|c|c|}
\hline $\begin{array}{l}\text { Name of } \\
\text { Formulas }\end{array}$ & Ingredients & Efficacy & Usage Mode & $\begin{array}{c}\text { Model/Strains } \\
\text { (Registration number) }\end{array}$ & $\begin{array}{l}\text { Dosage/ } \\
\text { Duration }\end{array}$ & $\begin{array}{l}\mathrm{IC}_{50}, \mathrm{EC}_{50} \\
\mathrm{TCID}_{50}, \mathrm{TC}_{50} \\
\mathrm{TC}_{0}, \mathrm{LD}_{0} \\
\text { LD }_{50^{*}}\end{array}$ & Control & $\begin{array}{l}\text { Actions and } \\
\text { mechanisms }\end{array}$ & References \\
\hline $\begin{array}{l}\text { Venting- } \\
\text { releasing } \\
\text { Epidemic- } \\
\text { dispelling } \\
\text { Granule (Toujie } \\
\text { Quwen Keli) }\end{array}$ & 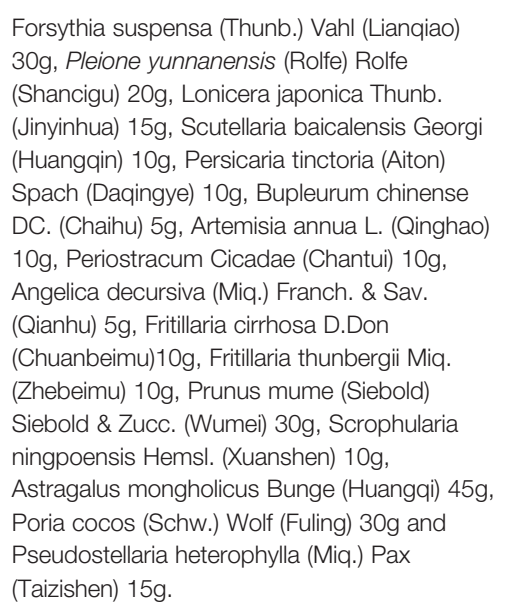 & $\begin{array}{l}\text { Clear heat } \\
\text { and resolve } \\
\text { toxins, vent } \\
\text { the exterior } \\
\text { and scatter } \\
\text { wind, boost } \\
\text { qi and } \\
\text { nourish yin. }\end{array}$ & $\begin{array}{l}\text { Water } \\
\text { solution }\end{array}$ & $\begin{array}{l}\text { Randomized parallel } \\
\text { controlled study: } 65 \\
\text { cases of patients with } \\
\text { COVID-19. }\end{array}$ & $\begin{array}{l}0.883 \mathrm{~g} / \mathrm{ml}, \\
300 \mathrm{ml} / \mathrm{day}\end{array}$ & - & $\begin{array}{l}\text { Arbidol, } \\
\text { moxifloxacin }\end{array}$ & $\begin{array}{l}\text { Reduces the symptoms } \\
\text { of patients with novel } \\
\text { coronavirus pneumonia, } \\
\text { and regulates the } \\
\text { expression of peripheral } \\
\text { blood inflammatory } \\
\text { markers, decreases the } \\
\text { level of CRP and } \\
\text { increases the level of } \\
\text { CD+ to antagonize novel } \\
\text { coronavirus. }\end{array}$ & $\begin{array}{l}\text { Fu X. X. } \\
\text { et al., } 2020\end{array}$ \\
\hline $\begin{array}{l}\text { Lung-clearing, } \\
\text { Pathogen- } \\
\text { venting and } \\
\text { Healthy-qi- } \\
\text { reinforcing } \\
\text { Formula } \\
\text { (Qingfei Touxie } \\
\text { Fuzheng Fang) }\end{array}$ & $\begin{array}{l}\text { Ephedra sinica Stapf (Zhimahuang) 6g, } \\
\text { Gypsum Fibrosum (Shengshigao) 20g, Prunus } \\
\text { armeniaca L. (Xingren) } 10 \mathrm{~g} \text {, Forsythia suspensa } \\
\text { (Thunb.) Vahl (Lianqiao) } 15 \mathrm{~g} \text {, Phragmites } \\
\text { australis subsp. australis (Lugen) 30g, Lonicera } \\
\text { japonica Thunb. (Jinyinhua) 30g, Coix lacryma- } \\
\text { jobi var. ma-yuen (Rom.Caill.) Stapf (Yiyiren) } \\
\text { 30g, Bombyx Batryticatus (Jiangcan) 10g, } \\
\text { Periostracum Cicadae (Chantui) 10g, } \\
\text { Reynoutria japonica Houtt. (Huzhang) 15g, } \\
\text { Curcuma longa L. (Jianghuang) 10g, Paeonia } \\
\text { lactiflora Pall. (Baishao) 10g, Pseudostellaria } \\
\text { heterophylla (Miq.) Pax (Taizishen) } 20 \mathrm{~g} \text { and } \\
\text { Glycyrrhiza uralensis Fisch. ex DC. } \\
\text { (Shenggancao) } 15 \mathrm{~g} \text {. }\end{array}$ & $\begin{array}{l}\text { Clear and } \\
\text { diffuse lung } \\
\text { heat, and } \\
\text { reinforce } \\
\text { healthy qi to } \\
\text { consolidate } \\
\text { the exterior. }\end{array}$ & Decoction & $\begin{array}{l}\text { Randomized controlled } \\
\text { study: Novel } \\
\text { coronavirus pneumonia } \\
\text { patients }\end{array}$ & $\begin{array}{l}0.77 \mathrm{~g} / \mathrm{ml} ; \\
300400 \mathrm{ml} / \\
\text { day }\end{array}$ & - & Interferon- $\alpha$ & $\begin{array}{l}\text { Relieves the clinical } \\
\text { symptoms of fever, } \\
\text { cough and } \\
\text { expectoration, chest } \\
\text { tightness and shortness } \\
\text { of breath, promotes the } \\
\text { absorption of lung } \\
\text { lesions and improves } \\
\text { oxygenation, and } \\
\text { reduces the content of } \\
\text { CRP, ESR and IL-6, and } \\
\text { increases the expression } \\
\text { of IFN- } \gamma \text { to antagonize } \\
\text { novel coronavirus. }\end{array}$ & $\begin{array}{l}\text { Ding et al., } \\
2020\end{array}$ \\
\hline
\end{tabular}

${ }^{*} C_{50}, 50 \%$ inhibiting concentration; $E C_{50}, 50 \%$ maximal effective concentration; $T C I D_{50}, 50 \%$ tissue culture infectious dose; $T C_{50}$, median toxic concentration. $T C_{0}, M a x i m u m$ nontoxic concentration; $L D_{50}$, median lethal dose; $L D_{0}$, lethal dose. 
and invigorate blood, boost qi and nourish yin, relieve cough and calm panting, Formula III for SARS during Convalescence (Feidian Huifuqi Sanhao Fang) with recovery to boost qi and nourish yin, fortify the spleen and harmonize the stomach. The results showed that the remission time of clinical symptoms and reduced hormone usage in the integrated TCM western medicine group were 2.52 days and $222.69 \mathrm{mg}$ respectively, shorter than those in the control group, and the difference was statistically significant difference $(p<0.05)$. Moreover, TCM also played an important role in promoting the recovery of immune function and reducing pulmonary inflammatory injury (Zhang R. L. et al., 2003). Yunling Zhang et al. employed integrated TCM and western medicine to treat 65 SARS patients, prescribing SARSFormula-I (Feidian Yihao Fang) at the high fever stage to clear heat and resolve toxins, dispel dampness and remove turbidity; SARS-Formula-II (Feidian Erhao Fang) at panting and oppression stage to clear and dissolve damp-heat, diffuse the lung and direct counterflow downward; and SARS-Formula-III (Feidian Sanhao Fang) at the absorbing stage to boost qi and nourish yin, dissolve phlegm and invigorate blood, drain dampness and direct turbidity downward, respectively. The results showed that the treatment of integrated traditional Chinese and western medicine had advantages over the western medicine alone in terms of reducing fever, relieving clinical symptoms, absorbing pulmonary inflammatory lesions and reducing hormone usage $(p<0.001$ or $p<0.05)$ (Zhang Y. L. et al., 2003). Jianping Liu et al. performed meta-analysis on the treatment of SARS with integrated Chinese and western medicine, and found that the combined Chinese and western medicine treatment could shorten the clinical symptoms and fever time, reduce secondary fungal infection, and relieve pulmonary inflammation (Liu et al., 2005).

\section{TCM for the Treatment of Influenza Virus Pneumonia}

Influenza virus pneumonia is a common pulmonary infection disease in clinic. Its symptoms often see fever, cough, bitter taste in the mouth, dry throat, throat pain, even visible high fever, heavy panting, profuse sweating, etc. Shouchuan Wang et al. used Lung-clearing Oral Liquid (Qingfei Koufuye) with effects of diffusing the lung and dissolving phlegm, resolving toxins and invigorating blood to treat infantile viral pneumonia with a pattern of phlegm-heat blocking the lung. The results showed the efficacy of Lung-clearing Oral Liquid was better than ribavirin injection in term of reducing fever, cough, asthma and inflammation $(p<0.05$ or $p<0.01)$ (Wang et al., 2016). Based on the conventional treatment, Youzhong Tian et al. gave Two Roots Lung-clearing Beverage (Ergen Qingfei Yin) and Phlegm-heat-clearing Injection (Tanreqing Zhusheye) to treat patients with $\mathrm{A}(\mathrm{H} 1 \mathrm{~N} 1)$ viral pneumonia. The results showed that compared with the western medicine control group, combining Chinese and western medicine treatment could significantly reduce the content of serum inflammatory cytokines, such as TNF-alpha, IL-6, IL-8 and c-reactive protein, and the antipyretic and antitussive effect was better than that of the control group $(p<0.01)$ (Tian et al., 2019). Fengmei Sang et al. used Sweet Wormwood and Scutellaria Gallbladder-Clearing Decoction (Haoqin Qingdan Tang) to treat patients with virus pneumonia with a pattern of damp-heat for a week as the observation group; the level of CD3+ and CD4+ was significantly higher than that of the control group patients (receiving conventional treatment); and the level of NF- $\mathrm{KB}$ was significantly lower than that of the control group patients $(p<0.05)$. The total effective rate of the observation group was higher than that of the control group, with statistical significance $(p<0.05)$ (Sang et al., 2014).

\section{TCM for the Treatment of Coronavirus Induced Disease 2019 (COVID-19)}

Coronavirus induced disease 2019 is a novel coronavirus pneumonia and characterized by fever, dry cough and fatigue as the main symptoms, accompanied by nasal congestion, runny nose, sore throat, muscle soreness and pain, etc. In severe cases, breathing difficulties and hypoxemia will occur, or patients develop into acute respiratory distress syndrome, septic shock, uncorrectable metabolic acidosis, coagulation dysfunction, and multi-organ failure and so on (General Office of National Health Commission of the People's Republic of China and Office of National Administration of TCM, 2020). TCM classifies COVID-19 as "epidemic disease". Raoqiong Wang et al. applied Lung-clearing and Toxin-expelling Decoction (Qingfei Paidu Tang) to treat 98 patients with COVID-19 and found that Lung-clearing and Toxin-expelling Decoction could significantly improve the liver and kidney functions of patients such as ALT and AST, recover the D-dimer, plasma C-reactive protein and erythrocyte precipitation, significantly reduce fever, cough (dry cough), asthma, pharyngeal pain, fatigue, anorexia and other symptoms, as well as relieve adverse reactions of antiviral drugs $(p<0.01)$ (Wang R. Q. et al., 2020). Compared to 36 COVID-19 patients treated with oral abidor tablets and ambroxol tablets as the control group, Xiaoxia Fu et al. applied Venting-releasing Epidemic-dispelling Granule (Toujie Quwen Keli) to 37 COVID19 patients as the treatment group. The results showed that compared with the western medicine treated control group, the combination of Chinese and western medicine treatment group can increase the absolute lymphocyte value and decrease Creactive protein. $\mathrm{CD} 4+$ count and $\mathrm{CD} 4+/ \mathrm{CD} 8+$ ratio were better than those in the control group $(\mathrm{p}<0.05)$ (Fu X. X. et al., 2020). Yunfei $\mathrm{Qu}$ et al. used the modified Ephedra, Apricot Kernel, Gypsum and Licorice Decoction (Maxingshigan Tang) [Ephedra sinica Stapf (Mahuang), Prunus armeniaca L. (Xingren), Gypsum Fibrosum (Shengshigao), Platycodon grandiflorus (Jacq.) A. DC. (Jiegeng), Eriobotrya japonica (Thunb.) Lindl. (Pipaye), Atractylodes macrocephala Koidz. (Baizhu), Poria cocos (Schw.) Wolf (Fuling), Fritillaria cirrhosa D.Don (Chuanbeimu), Scutellaria baicalensis Georgi (Huangqin), Morus alba L. (Sangbaipi) and Glycyrrhiza uralensis Fisch. ex DC. (Zhigancao)] with conventional western medicine to treat 40 patients with ordinary COVID-19, and found that after three days of treatment, IL-6 level significantly decreased compared with that before the treatment $(p<0.05)$, and levels of AST, ALT and creatinine were normal. After 7 days of treatment, IL- 6 level 
decreased to normal, hypersensitive C-reactive protein level decreased significantly, CD4+T and CD8+T cell count increased significantly compared with that before treatment $(p<0.05)$, levels of AST, ALT and creatinine were still normal. The results showed that this modified decoction had a significant effect on common COVID-19 without significant hepatorenal toxicity (Qu Y. F. et al., 2020). Ming Liu et al. evaluated the combination of traditional Chinese and western medicine for treatment of COVID-19. Based on the treatment with Lungclearing, Pathogen-venting and Healthy-qi-reinforcing Formula (Qingfei Touxie Fuzheng Fang), Wind-scattering Toxinsresolving Capsule (Shufeng Jiedu Jiaonang), and Lonicera and Forsythia Epidemic-Clearing Granule (Lianhua Qingwen Keli) and so on respectively, the combination of traditional Chinese medicine and western medicine had better outcome than western medicine alone in several clinical aspects such as reducing severe conversion rate, shortening hospitalization time and improving the patients' clinical symptoms such as fever, cough, fatigue and oppression in chest (Liu et al., 2020). Furthermore, there are many other proprietary traditional Chinese medicine products also play an important therapeutic role by direct antiviral actions, antipyretic and analgesic, immune-regulation, antiinflammation, and anti-acute lung injury, such as Agastache Qi-Correcting Capsule (Huoxiang Zhengqi Jiaonang), Lonicera Fever-clearing Granule (Jinhua Qinggan Keli), Wind-scattering Toxin-resolving Capsule (Shufeng Jiedu Jiaonang), Xiyanping Injection (Xiyanping Zhusheye), Blood-clearing Injection (Xuebijing Zhusheye), Ginseng and Aconite Injection (Shenfu Zhusheye), Ginseng and Ophiopogon Injection (Shenmai Zhusheye), Peaceful Palace Bovine Bezoar Pill (Angong Niuhuang Wan), etc. (Zhuang et al., 2020).

\section{DISCUSSION}

In the treatment of viral pneumonia through syndrome differentiation, TCM plays a variety of roles in inhibiting the proliferation, replication, adsorption and membrane penetration of the virus, promoting the expression of interferon in vivo, inhibiting inflammatory reaction, enhancing immunity, etc., which is one of the theoretical bases for the clinical application of TCM in the prevention and treatment of viral pneumonia. Viruses with RNA genetic material, such as influenza virus and coronavirus, are more likely to mismatch and cause mutations in the replication process than DNA viruses (Woolhouse et al., 2016). Their high variability makes it more difficult to develop vaccines and more susceptible to drug resistance to single chemical drugs. Traditional Chinese herbal medicine and compound medicinals are characterized by multi-component, multi-pathway and multi-pathway complex networks. Therefore, drug resistance is relatively rare in the clinical practice of TCM. Moreover, in the process of diagnosis and treatment of TCM, treatment based on differentiation of symptoms and signs, especially treatment based on classification of symptoms and signs, can best reflect the overall concept of TCM. TCM has precise therapeutic activity and less adverse reactions.
Accumulating evidence has demonstrated the competent therapeutic effects of TCM against viral pneumonia with a prominent safety profile. TCM has obvious characteristics and great advantages on syndrome differentiation for the prevention and treatment of viral pneumonia before specific antiviral drugs and vaccines are developed and produced. However, TCM in treatment of viral pneumonia still have some problems. First, theoretical study of viral pneumonia in TCM, especially regarding the pathogenesis and changes of the virus are not comprehensive, systematic and in-depth; second, the complexity of traditional Chinese herbal medicine composition and its compound makes it difficult to understand mechanism and action and less specific; third, in the process of treatment of viral pneumonia, it is usually carried out by traditional and macroscopic methods, with strong subjectivity, which cannot be considered as microscopic and specific as modern medical diagnostic standards. There is still a lack of recognized and unified standards for the classification of TCM Syndrome of viral pneumonia; fourth, the basic research on prevention and treatment of SARS-CoV-2 and COVID-19 with TCM is less developed, which may be related to that case collection of infectious disease in different countries is different or may not be allowed, and/or lack of laboratories that meet the requirements for conducting research of contagious diseases. Furthermore, the TCM treatment was mainly based on decoction, which makes difficult to set up control group therefore, generate greater varieties.

The basic treatment of medical formula and proprietary traditional Chinese medicine product are mainly based on the analysis of the whole process of the etiology and pathogenesis of viral pneumonia, which include grasping the basic pathogenesis, establishing the basic treatment method, and combining the viewpoint of modern medicine, formulating the basic prescriptions, or adding or subtracting along with the syndromes, or further changing the dosage form, and developing the treatment method for patent medicine. Although this kind of treatment often lacks the concept of TCM syndrome and the flexibility of syndrome differentiation and treatment, it has been proved to be effective in practice due to its grasp of the basic pathogenesis of the disease and the application of various methods. Moreover, it has been reported successful many times and seems to become a distinct alternative choice alongside the classical approach. Furthermore, in addition to oral administration of TCM decoction or pills, intravenous administration of TCM and other methods have been reported as another treatment of viral pneumonia. In addition, there are also many reports about the external treatment of patients with viral pneumonia, such as the atomizing inhalation of traditional Chinese medicine extract, external application of Chinese medicine powder or paste, foot reflexology, infantile massage, etc., all which reveal some new ideas and ways for TCM treatment of viral pneumonia.

In recent years, researches on viral pneumonia by TCM mainly focus on influenza virus, mainly on mice or cell models infected by influenza A (H1N1) virus, while researches on SARS$\mathrm{CoV}$ and MERS-CoV are few. Studies on such viruses as SARS- 
CoV, MERS-COV, H1N1 and other viruses should be conducted in P3 laboratory (biosafety level 3 laboratory) or higher biosafety laboratory. Extensive and in-depth studies on the prevention and treatment of viral diseases with TCM are subject to certain conditions. Fortunately, in 2020, the Ministry of Science and Technology of China issued the "Guidance on Strengthening the Biosafety Management of Novel Coronavirus High-level Virus Microbiology Laboratory", requiring the laboratory to play a role as a platform to serve the needs of scientific and technological research. This will provide strong policy support for the in-depth study of the antiviral effect and mechanism of TCM. Although the research on the antiviral activity of TCM has been performed with molecular biology, the specific therapeutic effects of traditional Chinese herbal medicine or compound on virus and pneumonia remains to be further investigated because of its complex components. Therefore, in order to better treat viral pneumonia with TCM based on syndrome differentiation and the overall concept of theoretical system, we should adhere to the theory of TCM as the basis, actively combine with modern or western medicine, complement each other, and use modern science and technology to explore the role and mechanism of viral pneumonia and traditional Chinese medicine in a more comprehensive, systematic and in-depth way, deeply analyze the characteristics of viral pneumonia syndromes, unify evidence pattern classification standards, further standardize and unify the evaluation criteria of syndrome differentiation and efficacy in order to facilitate the communication of clinical and scientific research work, use new diagnostic techniques to prevent misdiagnosis and missed diagnosis, and establish positive drug control in a standardized way in the process of clinical research to improve the credibility of TCM treatment. In the future, the TCM treatment theory and clinical application of viral pneumonia should pay special attention to strengthen experimental research, especially the effective Chinese medicine compounds. The precise mechanism of Chinese medicine in the treatment of viral pneumonia should be scientifically clarified to achieve the synchronization of clinical research and

\section{REFERENCES}

Amarelle, L., Lecuona, E., and Sznajder, J. I. (2017). Anti-influenza treatment: drugs currently used and under development. Arch. Bronconeumol. 53, 19-26. doi: 10.1016/j.arbres.2016.07.004

Bao, Y. Y., Gao, Y. J., Shi, Y. J., Bao, L., Yao, R. M., Mao, X., et al. (2019). Study on broad-spectrum antiviral effect of Shufeng Jiedu Capsules. J. New Chin. Med. 51, 5-8. doi: 10.13457/j.cnki.jncm.2019.12.002

Bi, Q. Y., Zhang, G. J., Cui, Y. L., Wang, M. R., and Ji, X. M. (2019). Multi target intervention effect of Ganlu Xiaodu Dan on mice model of viral pneumonia with damp-heat syndrome. Lishizhen Med. Mater. Med. Res. 30, 1840-1844. doi: 10.3969/j.issn.1008-0805.2019.08.017

Casadevall, A., and Pirofski, L. A. (2014). Microbiology: Ditch the term pathogen. Nature 516, 165-166. doi: 10.1038/516165a

Chen, K. T., Zhou, W. L., Liu, J. W., Zu, M., He, Z. N., Du, G. H., et al. (2012). Active neuraminidase constituents of Polygonum cuspidatum against influenza A (H1N1) influenza virus. Chin. J. Chin. Mater. Med. 37, 30683073. doi: $10.4268 /$ cjcmm 20122014

Chen, W. X., Han, Z. Z., Yang, T. C., Ma, Q., Zhan, R. T., Tan, Y., et al. (2016). Comparative study on effect of Ilex asprella root and stem against respiratory experimental research. In this way, Chinese medicine can be better to treat patients with viral pneumonia in a scientific and standardized manner based on syndrome differentiation.

\section{CONCLUSIONS}

TCM has been widely used in basic and clinical researches of virus diseases especially viral pneumonia in human. Some Chinese medicine has shown certain therapeutic effect, but high-quality experimental design and randomized clinical controlled study are still needed. A wide variety of antiviral traditional Chinese herbal medicines also provides potential opportunity for further development in specific therapeutic agents to treat viral pneumonia around the world.

\section{AUTHOR CONTRIBUTIONS}

YL and SX wrote the manuscript. YL and LY helped in searching for related articles. Y'aY, LQ, TL, and SX proofread the manuscript. SX and YG guided the writing and critically revised the manuscript. All authors contributed to the article and approved the submitted version.

\section{FUNDING}

This work was supported by the Fundamental Research Funds for the Central Universities of China (No.20720200012), Beijing University of Chinese Medicine Research Project (No.2020-JYBYJ-004) (Emergent project for the prevention and control of coronavirus pneumonia) and the Top Young Scientist Funds and Top Young Doctor Funds of Beijing University of Chinese Medicine (No.BUCM-2019-JCRC007 and BUCM2019-QNMYB011). viruses. Mod. Chin. Med. 18 156-160, 163. doi: 10.13313/j.issn.16734890.2016.2.006

Chen, G., Wu, Q. F., Zhang, X. X., and Yan, Y. L. (2017). Effects of nine compatibility proportions of Coptidis Rhizoma-Magnoliae officinalis Cortex drug pair on the inhibition of neuraminidase activity. Chin. Tradit. Pat. Med. 39, 1394-1397. doi: 10.3969/j.issn.1001-1528.2017.07.014

Chen, J., Wang, Y. K., Gao, Y., Hu, L. S., Yang, J. W., Wang, J. R., et al. (2020). Protection against COVID-19 injury by Qingfei Paidu decoction via anti-viral, anti-inflammatory activity and metabolic programming. Biomed. Pharmacother. 129, 110281. doi: 10.1016/j.biopha.2020.110281

Chen, L., Cheng, Z. Q., Liu, F., Xia, Y., and Chen, Y. G. (2020). Analysis of 131 cases of COVID-19 treated with Ganlu Xiaodu Decoction. Chin. J. Chin. Mater. Med. 45, 2232-2238. doi: 10.19540/j.cnki.cjcmm.20200322.505

China Association of Chinese Medicine (2003). Guidelines for the diagnosis and treatment of SARS. J. Tradit. Chin. Med. 44, 865-871. doi: 10.13288/j.11-2166/ r.2003.11.039

Chiow, K. H., Phoon, M. C., Putti, T., Tan, B. K. H., and Chow, V. T. (2016). Evaluation of antiviral activities of Houttuynia cordata Thunb. extract, quercetin, quercetrin and cinanserin on murine coronavirus and dengue virus infection. Asian Pac. J. Trop. Med. 9, 1-7. doi: 10.1016/j.apjtm.2015.12.002 
Cinatl, J., Morgenstern, B., Bauer, G., Chandra, P., Rabenau, H., and Doerr, H. W. (2003). Glycyrrhizin, an active component of Liquorice roots, and replication of SARS-associated coronavirus. Lancet 361, 2045-2046. doi: 10.1016/s01406736(03)13615-X

Cui, Y. R., Jie, Z., Li, H. L., Huang, X. T., Zhang, M. Y., Qiu, S. Y., et al. (2019). The research on dose-effect relationship of MaxingShiganTang in RSV infected pneumonia of rat model. Pharm. Clin. Chin. Mater. Med. 35, 33-37. doi: 10.13412/j.cnki.zyyl.2019.03.007

Deng, T. T. (2003). Discussion on the diagnosis and treatment of atypical pneumonia with traditional Chinese medicine. J. New Chin. Med. 35, 3-5. doi: 10.3969/j.issn.0256-7415.2003.06.001

Deng, G. A. (2006). Experimental research on the effect of Kangliyin on mouse pneumonia caused by FM1 strain of type A influenza virus (Guangzhou: Guangzhou University of Chinese Medicine).

Der, S. D., and Lau, A. S. (1995). Involvement of the double-stranded-RNAdependent kinase PKR in interferon expression and interferon-mediated antiviral activity. Proc. Natl. Acad. Sci. USA. 92, 8841-8845. doi: 10.1073/ pnas.92.19.8841

Ding, Y., Dou, J., Teng, Z. J., Yu, J., Wang, T. T., Lu, N., et al. (2014). Antiviral activity of baicalin against influenza $\mathrm{A}(\mathrm{H} 1 \mathrm{~N} 1 / \mathrm{H} 3 \mathrm{~N} 2)$ virus in cell culture and in mice and its inhibition of neuraminidase. Arch. Virol. 159, 3269-3278. doi: 10.1007/s00705-014-2192-2

Ding, Y. W., Zeng, L. J., Li, R. F., Chen, Q. Y., Zhou, B. X., Chen, Q. L., et al. (2017). The Chinese prescription lianhuaqingwen capsule exerts anti-influenza activity through the inhibition of viral propagation and impacts immune function. BMC Complement. Altern. Med. 17, 130. doi: 10.1186/s12906-017-1585-7

Ding, X. J., Zhang, Y., He, D. C., Zhang, M. Y., Tan, Y. J., Yu, A. Y., et al. (2020). Clinical effect and mechanism of Qingfei Touxie Fuzheng Recipe in the treatment of COVID-19. Herald Med. 39, 640-644. doi: 10.3870/j.issn.10040781.2020.05.012

Dong, W. G., Yuan, B., Zhou, L. H., Xu, J. Y., Li, J. Q., Wang, M. M., et al. (2015). Effects of Qingfei Oral Liquid on the expressions of IL-10 and IL-17 in the lung tissue and those of Treg and Th17 in the spleen of RSV-infected mice. J. Med. Postgra. 28, 1242-1245. doi: 10.16571/j.cnki.1008-8199.2015.12.003

Dong, D. G., Zhang, X. Y., and Liu, X. X. (2016a). Influence of different effective parts of Mulberry on respiratory syncytial virus index and viral load in the pneumonia rats. World J. Integr. Tradit. West. Med. 11, 785-787. doi: 10.13935/j.cnki.sjzx.160612

Dong, D. G., Liu, X. X., Zhang, X. Y., and Wang, Y. H. (2016b). Effects of Morus alba L. polysaccharide on lung tissue and T lymphocyte subtype in mice infected by respiratory syncytial virus. Anhui Med. Pharm. J. 20, 1841-1844. doi: 10.3969/j.issn.1009-6469.2016.10.007

Duan, L. J., Zhang, Q., Wang, N. R., Yang, B., He, S. Q., and Sun, J. (2012). Effect of Phillyrin on gene expression of influenza A virus nucleoprotein. Chin. Gen. Pract. 15, 2082-2084. doi: 10.3969/j.issn.1007-9572.2012.06.101

Efferth, T., Romero, M. R., Wolf, D. G., Stamminger, T., Marin, J. J., and Marschall, M. (2008). The antiviral activities of artemisinin and artesunate. Clin. Infect. Dis. 47, 804-811. doi: 10.1086/591195

Enkhtaivan, G., Kim, D. H., Park, G. S., Pandurangan, M., Nicholas, D. A., Moon, S. H., et al. (2018). Berberine-piperazine conjugates as potent influenza neuraminidase blocker. Int. J. Biol. Macr. 119, 1204-1210. doi: 10.1016/ j.ijbiomac.2018.08.047

Figueiredo, L. T. (2009). Viral pneumonia: epidemiological, clinical, pathophysiological and therapeutic aspects. J. Bras. Pneumol. 35, 899-906. doi: 10.1590/s1806-37132009000900012

Fu, L. C., Xu, P. P., Liu, N., Yang, Z. F., Zhang, F. X., and Hu, Y. J. (2008). Antiviral effect of Arctigenin compound on influenza virus. Tradit. Chin. Drug Res. Clin. Pharm. 19, 266-269. doi: 10.19378/j.issn.1003-9783.2008.04.008

Fu, X. L., Fan, D., Liu, Y. X., Fang, B., Liu, W. J., Tian, Y. B., et al. (2020). Antiinfluenza virus and mechanise of glycryrrhizin. Chin. J. Veter. Sci. 40, 330-335. doi: 10.16303/j.cnki.1005-4545.2020.02.18

Fu, X. X., Lin, L. P., and Tan, X. H. (2020). Clinical study on 37 cases of COVID-19 treated with integrated traditional Chinese and western medicine. Tradit. Chin. Drug Res. Clin. Pharm. 31, 600-604. doi: 10.19378/j.issn.1003-9783. 2020.05.016

Gao, D., Niu, M., Wei, S. Z., Zhang, C. E., Zhou, Y. F., Yang, Z. W., et al. (2020). Identification of a pharmacological biomarker for the bioassay-based quality control of a thirteen-component TCM formula (Lianhua Qingwen) used in treating influenza A virus (H1N1) infection. Front. Pharmacol. 11, 746. doi: 10.3389/fphar.2020.00746

Ge, S. J., Lu, N. N., Liu, X. T., Zhang, Y., Gu, L. G., Wu, J., et al. (2015). Effect of Shufeng Xuanfei Formula and Jiebiao Qingli Formula on TLR3/7 signal pathway in human pulmonary carcinoma cell A549 infected by influenza virus $\mathrm{H} 1 \mathrm{~N} 1$ and its mechanism. Acta Chin. Med. Pharm. 43, 23-26. doi: 10.19664/j.cnki.1002-2392.2015.02.007

General Office of National Health Commission of the People's Republic of China, and Office of National Administration of Traditional Chinese Medicine (2020). Diagnosis and treatment of corona virus disease19 (7th trial edition). Chin. Med. 15, 801-805. doi: 10.3760/j.issn.1673-4777.2020.06.001

Geng, Z. K., Li, Y. Q., Cui, Q. H., Du, R. K., and Tian, J. Z. (2019). Exploration of the mechanisms of Ge Gen Decoction against influenza A virus infection. Chin. J. Nat. Med. 17, 0650-0662. doi: 10.1016/S1875-5364(19)30079-2

Gou, L., He, T., Zeng, N., Liu, J. W., Gong, X. P., Wang, Z., et al. (2013). Study on the antiviral action of serum containing volatile oil of Schizonepetae and Ramulus cinnamomi in vitro. Lishizhen Med. Mater. Med. Res. 24, 19-21. doi: 10.3969/j.issn.1008-0805.2013.01.009

Guan, W. D., Du, Q. L., Jiang, H. M., Zhao, J. C., and Yang, Z. F. (2018). Comparison of inhibitory effects of arbidol and Lianhuaqingwen Capsules on Middle East respiratory syndrome coronavirus in vitro and in vivo. Guangdong Med. J. 39, 3454-3458. doi: 10.13820/j.cnki.gdyx.20181221.014

Guo, S. S., Huang, Y., Zhao, Y., Gao, Y. J., Gong, W. F., and Cui, X. L. (2007). Effect of extracted ZG from Gardenia on Hep-2 cell membrane post infected with parainfluenza virus type 1(PIV-1). Chin. J. Virol. 24, 384-388. doi: 10.3321/ j.issn:1000-8721.2007.05.009

Harikrishnan, H., Jantan, I., Haque, M. A., and Kumolosasi, E. (2018). Antiinflammatory effects of Phyllanthus amarus Schum. \& Thonn. through inhibition of NF- $\mathrm{KB}, \mathrm{MAPK}$, and PI3K-Akt signaling pathways in LPSinduced human macrophages. BMC Complement. Altern. Med. 18, 224. doi: 10.1186/s12906-018-2289-3

Hayashi, K., Narutaki, K., Nagaoka, Y., Hayashi, T., and Uesato, S. (2010). Therapeutic effect of Arctiin and Arctigenin in immunocompetent and immunocompromised mice infected with influenza A virus. Biol. Pharm. Bull. 33, 1199-1205. doi: 10.1248/bpb.33.1199

He, T., Chen, Y., Zeng, N., Tang, Q., Gou, L., Liu, J. W., et al. (2012). Study on the effect and mechanism of anti-influenza A virus of the volatile oil of Herba Schizonepetae Briq. in vitro. Pharmacol. Clin. Chin. Mater. Med. 28, 51-55. doi: 10.13412/j.cnki.zyyl.2012.03.041

He, T., Tang, Q., Zeng, N., Gou, L., Liu, J. W., Yang, J., et al. (2013). Study on effect and mechanism of volatile oil of Schizonepetae Herba and its essential components against influenza virus. Chin. J. Chin. Mater. Med. 38, 17721777. doi: 10.4268/cjcmm20131125

Ho, T. Y., Wu, S. L., Chen, J. C., Li, C. C., and Hsiang, C. Y. (2007). Emodin blocks the SARS coronavirus spike protein and angiotensin-converting enzyme 2 interaction. Antiviral Res. 74, 92-101. doi: 10.1016/j.antiviral.2006.04.014

Hou, X. B., Fan, F. T., and He, L. W. (2017). Regulation effect of Isatidis radixcontaining serum on TLR3 signal transduction pathway in RAW264.7 cells infected with virus. Chin. J. Exper. Tradit. Med. Form. 23, 105-111. doi: 10.13422/j.cnki.syfjx.2017090105

Hsieh, C. F., Lo, C. W., Liu, C. H., Lin, S. M., Yen, H. R., Lin, T. Y., et al (2012). Mechanism by which Ma-Xing-Shi-Gan-Tang inhibits the entry of influenza virus. J. Ethnopharmacol. 143, 57-67. doi: 10.1016/j.jep.2012.05.061

Huang, C. L., Wang, Y. M., Li, X. W., Ren, L. L., Zhao, J. P., Hu, Y., et al. (2020). Clinical features of patients infected with 2019 novel coronavirus in Wuhan, China. Lancet 395, 497-506. doi: 10.1016/S0140-6736(20)30183-5

Jain, S. (2017). Epidemiology of viral pneumonia. Clin. Chest Med. 38, 1-9. doi: 10.1016/j.ccm.2016.11.012

Lai, P. H., Lin, P. Z., Wang, X. P., Liu, Y., Xu, Q. Y., Zhang, F. X., et al. (2011). Effects of Haoqinqingdan Decoction and its disassembled recipes on dampheat syndrome of influenza viral pneumonia and NF- $\mathrm{KB}$ expression. Chin. J. Tradit. Chin. Med. Pharm. 26, 2074-2076.

Lang, S., Yan, Y. T., Liu, C., Yang, J., Wang, Z. J., and Gao, Z. P. (2019). Screening of influenza virus neuraminidase inhibitors from Osmunda japonica. Mod. Chin. Med. 211497-1504, 1511. doi: 10.13313/j.issn.16734890.20190109007

Law, A. H., Yang, C. L., Lau, A. S., and Chan, G. C. (2017). Antiviral effect of forsythoside A from Forsythia suspensa (Thunb.) Vahl fruit against influenza A 
virus through reduction of viral M1 protein. J. Ethnopharmacol. 209, 236-247. doi: 10.1016/j.jep.2017.07.015

Li, X., Yang, X. J., Tian, W. J., and Li, H. Y. (2008). Action of an active compound RG2-1 from Radix Gentianae on antirespiratory syncytial virus in vitro. J. Hygiene Res. 37, 591-593. doi: 10.3969/j.issn.1000-8020.2008.05.025

Li, H. B., Yan, D., Wang, J. B., Wang, J. Y., Bei, Z. C., Wei, L., et al. (2009). Biological evaluation of Radix Isatidis based on neuraminidase activity assay. Acta Pharm. Sin. 44, 162-166. doi: 10.16438/j.0513-4870.2009.02.007

Li, C. G., Yang, P. H., Zhang, Y. L., Sun, Y., Wang, W., Zou, Z., et al. (2012). Corticosteroid treatment ameliorates acute lung injury induced by 2009 swine origin influenza A (H1N1) virus in mice. PloS One 7, e44110. doi: 10.1371/ journal.pone.0044110

Li, Y. H., Li, X. X., Chen, J. Q., Wang, Y. X., Zhao, Y. L., Wu, Y., et al (2013). Effect of EFFL on cytokines in BALB/c mice infected by swine influenza virus. J. Northeast Agric. Univ. 44, 6-9. doi: 10.19720/j.cnki.issn.1005-9369.2013.12.002

Li, X. L., Lu, G. F., Yi, D. F., Li, L., Fan, F. Y., Ge, Z. Y., et al (2015). Experimental research on the function of anti-influenza virus in vitro of Yinhuang Qingfei capsules containing serum. Chin. Arch. Tradit. Chin. Med. 33, 1107-1109. doi: 10.13193/j.issn.1673-7717.2015.05.024

Li, H. J., Huang, H. M., and Zuo, J. L. (2018). Immunoregulation mechanism study of Yinqiao Chai Gui Prescription II in mice inflected by influenza virus. Pharm. Clin. Chin. Mater. Med. 29, 449-453. doi: 10.19378/j.issn.1003-9783.2018.04.013

Li, K., Yang, Q., Zhou, T. T., Yan, S. C., Weng, X. G., Yang, L., et al. (2019). Protective effect of phenolic compound of Osmundae rhizoma on systemic inflammatory response syndrome in mice. Chin. J. Exp. Tradit. Med. Form. 25, 55-60. doi: 10.13422/j.cnki.syfjx.20190909

Li, J. (2013). The isolation and purification of the polysaccharides from Radix isatidis, and their effects on the inhibition of influenza virus neuraminidase (Changchun: Northeast Normal University).

Li, M., Li, T. S., and Yang, Q. W. (2020). To observe the protective mechanism of resveratrol on mice caused by respiratory syncytial virus based on PI3K/Akt signaling pathway. J. Chin. Med. Mater. 43, 989-993. doi: 10.13863/j.issn10014454.2020.04.038

Li, R. F., Hou, Y. L., Huang, J. C., Pan, W. Q., Ma, Q. H., Shi, Y. X., et al (2020). Lianhuaqingwen exerts anti-viral and anti-inflammatory activity against novel coronavirus (SARS-CoV-2). Pharmacol. Res. 156, 104761. doi: 10.1016/ j.phrs.2020.104761

Li, W. H. (2013). Clinical observation of Reduning injection in the treatment of viral pneumonia. Jilin Med. J. 34, 3593-3593. doi: 10.3969/j.issn.10040412.2013.18.051

Ling, L. J., Lu, Y., Zhang, Y. Y., Zhu, H. Y., Tu, P., Li, H., et al. (2020). Flavonoids from Houttuynia cordata attenuate H1N1-induced acute lung injury in mice via inhibition of influenza virus and Toll-like receptor signalling. Phytomedicine 67, 153150. doi: 10.1016/j.phymed.2019.153150

Liu, J. P., Manheimer, E., Shi, Y., and Gluud, C. (2005). Systematic review and meta-analysis on the integrative traditional Chinese and western medicine in treating SARS. Chin. J. Integr. Tradit. West. Med. 25, 1082-1088. doi: 10.3321/ j.issn:1003-5370.2005.12.006

Liu, X. Y., Li, H. Y., Wang, X. Q., Li, X., Zhang, F. M., Piao, Y. A., et al. (2006). The anti-respiratory syncytial virus effect of an active compound (GC3-1-4) from Glycyrrhiza in vitro. Infor. Tradit. Chin. Med. 23, 65-67. doi: 10.19656/ j.cnki.1002-2406.2006.04.038

Liu, R., He, T., Chen, T., Zeng, N., Tang, Q., Gou, L., et al. (2012). Study on the effect of antiinfluenza A virus of the volatile oil of Ramulus Cinnamomi. Pharm. Clin. Chin. Mater. Med. 28, 76-79. doi: 10.13412/j.cnki.zyyl. 2012.02.032

Liu, R., Gou, L., Yu, L., He, T., Yang, J., Wang, Z., et al. (2013). The effects of the volatile oil of Ramulus Cinnamomi and cinnamaldehyde on death protection rate in H1N1-infected mice and mechanism of TLR/IFN signal pathway. Pharm. Clin. Chin. Mater. Med. 29, 33-36. doi: 10.13412/j.cnki.zyyl.2013.04.050

Liu, Q., Wang, J. G., Ma, Y. P., and Gu, L. G. (2014). A research on the influence of two herbal concoctions on Toll-like receptor signal pathways of influenza virus induced pneumonia in mice. Chin. Crit. Care Med. 26, 321-324. doi: 10.3760/ cma.j.issn.2095-4352.2014.05.007

Liu, J. W., Zu, M., Chen, K. T., Gao, L., Min, H., Zhuo, W. L., et al. (2018). Screening of neuraminidase inhibitory activities of some medicinal plants traditionally used in Lingnan Chinese medicines. BMC Complement. Altern. Med. 18, 102. doi: 10.1186/s12906-018-2173-1
Liu, M., Gao, Y., Yuan, Y., Yang, K. L., Shi, S. Z., Zhang, J. H., et al (2020). Efficacy and safety of integrated traditional Chinese and western medicine for corona virus disease 2019 (COVID-19): a systematic review and meta-analysis. Pharmacol. Res. 158, 104896. doi: 10.1016/j.phrs.2020.104896

Liu, F., Cao, W., Deng, C., Wu, Z., Zeng, G., and Zhou, Y. (2016). Polyphenolic glycosides isolated from Pogostemon cablin (Blanco) Benth. as novel influenza neuraminidase inhibitors. Chem. Cent. J. 10, 51. doi: 10.1186/s13065-0160192-x

Liu, X. X., Wang, X. F., Zhang, X. Y., Wang, Y. H., Wang, S. Y., and Nan, C. H. (2016). Effect of Qingfei Tongluo paste on the PI3K/Akt/NF- אB signaling in rats infected with RSV. Chin. Pediatr. Integr. Tradit. West. Med. 8, 136-138, 249. doi: 10.3969/j.issn.1674-3865.2016.02.004

Liu, X. X. (2016). Experimental study on the regulation of PI3K/Akt signaling pathway in RSV pneumonia mice by the effective site of Morus alba $L$ (Shenyang: Liaoning University of Traditional Chinese Medicine).

Luo, W., Wang, J. Y., Liu, C. L., and Huang, C. (2014). Effect of electroacupuncture stimulation of "Feishu" (BL 13) on lung index, serum and lung IT-10 and TNF$\alpha$ levels in mice with viral pneumonia. Acupunt. Res. 39, 293-297. doi: 10.13702/j.1000-0607.2014.04.007

Luo, Z., Liu, L. F., Wang, X. H., Li, W., Jie, C., Chen, H., et al. (2019). Epigoitrin, an alkaloid from Isatis indigotica, reduces H1N1 infection in stress-induced susceptible model in vivo and in vitro. Front. Pharmacol. 10, 78. doi: $10.3389 /$ fphar.2019.00078

Ma, H. D., Deng, Y. R., Tian, Z. G., and Lian, Z. X. (2013). Traditional Chinese medicine and immune regulation. Clinic Rev. Allerg. Immunol. 44, 229-241. doi: 10.1007/s12016-012-8332-0

Ma, Q. H., Yu, Q. T., Xing, X. F., Liu, S. N., Shi, C. Y., and Luo, J. B. (2018). San Wu Huangqin Decoction, a Chinese herbal formula, inhibits influenza a/PR/8/34 (H1N1) virus infection in vitro and in vivo. Viruses 10, 117. doi: 10.3390/ v10030117

Ma, Q. H., Pan, W. Q., Li, R. F., Liu, B., Li, C. F., Xie, Y. Q., et al. (2020). Liu Shen capsule shows antiviral and anti-inflammatory abilities against novel coronavirus SARS-CoV-2 via suppression of NF- $\mathrm{\kappa B}$ signaling pathway. Pharmacol. Res. 158, 104850. doi: 10.1016/j.phrs.2020.104850

Mantani, N., Imanishi, N., Kawamata, H., Terasawa, K., and Ochiai, H. (2001). Inhibitory effect of $(+)$-catechin on the growth of influenza A/PR/8 virus in MDCK cells. Planta Med. 67, 240-243. doi: 10.1055/s-2001-12009

Min, J. Y., and Krug, R. M. (2006). The primary function of RNA binding by the influenza A virus NS1 protein in infected cells: Inhibiting the 2'-5' oligo (A) synthetase/RNase L pathway. Proc. Natl. Acad. Sci. U. S. A. 103, 7100-7105. doi: $10.1073 /$ pnas.0602184103

Mo, R. G., Han, X. M., Xin, Y., Wang, G. Z., and Dong, J. (2005). Experimental study on the inhibiting flu virus action of Haoqin Qinggan decoction. Tradit. Chin. Med. Res. 18, 16-18. doi: 10.3969/j.issn.1001-6910.2005.05.009

Nan, S. L., Xu, S. F., Chen, X., Li, F., Pan, J., Lv, M. A., et al. (2016a). Effects of Shengjiang San on ICAM-1 and NF- $\kappa B p 65$ expression in mouse lung tissues infected with influenza virus FM1. Pharm. Clin. Chin. Mater. Med. 32, 2-6. doi: 10.13412/j.cnki.zyyl.2016.06.001

Nan, S. L., Xu, S. F., Chen, X., Li, F., Lv, M. A., Li, J., et al. (2016b). Immunomodulatory effects of Shengjiang San on the mice infected with influenza virus FM1. Pharm. Clin. Chin. Mater. Med. 32, 8-13. doi: $10.13412 /$ j.cnki.zyyl.2016.05.003

National Administration of Traditional Chinese Medicine (NATCM) (2020). Traditional Chinese medicine has played an important role and become a highlight of the epidemic prevention and control. (2020-03-23). Available at: http://www.satcm.gov.cn/xinxifabu/meitibaodao/2020-0323/14195.html.

National Health and Family Planning Commission of People's Republic of China (2015). Guideline on diagnosis and treatment of Middle East respiratory syndrome, (2015 version). Chin. J. Viral. Dis. 5, 352-354. doi: 10.16505/ j.2095-0136.2015.05.005

National Health and Family Planning Commission of People's Republic of China (2017). Guideline on diagnosis and treatment of human infection with avian influenza A (H7N9) virus, (2017 version). Chin. J. Viral Dis. 7, 1-4. doi: 10.16505/j.2095-0136.2017.01.001

National Health Commission of the People's Republic of China (2020). Diagnosis and treatment for COVID-19 (trial $7^{\text {th }}$ version). J. Lanzhou Univ. (Med. Sci.). 46, 1-7. doi: 10.13885/j.issn.1000-2812.2020.02.001 
National Health Commission of the People's Republic of China, and National Administration of Traditional Chinese Medicine (2019). Protocol for diagnosis and treatment of influenza, (2019 version). Chin. J. Clin. Infect. Dis. 12, 451455. doi: 10.3760/cma.j.issn.1674-2397.2019.06.003

Peng, Z., Lu, F. G., Qu, J. Y., Li, L., Fan, F. Y., Na, J. J., et al. (2016). Experimental research of Yinhuang Qingfei capsules containing serum on the respiratory syncytial virus in vitro. J. Hunan Univ. Chin. Med. 36, 40-43. doi: 10.3969/ j.issn.1674-070X.2016.02.011

Qiu, Y., Zhang, S., and Zhang, M. H. (2018). Protective effect of Yinhuang Qingfei capsules on influenza virus pneumonia in juvenile rats. Centr. South Pharm. 16, 1240-1243. doi: 10.7539/j.issn.1672-2981.2018.09.014

Qu, X. K., Hao, S. L., Ma, J. H., Wei, G. Y., Song, K. Y., Tang, C., et al. (2020). Observation on clinical effect of Shufeng Jiedu Capsule combined with Arbidol Hydrochloride Capsule in treatment of COVID-19. Chin. Tradit. Herbal Drugs 51, 1167-1170. doi: 10.7501/j.issn.0253-2670.2020.05.011

Qu, Y. F., Fang, W., Jin, Y. Z., Qin, C., Niu, X. C., Zhang, N., et al. (2020). Forty cases of common COVID-19 treated with modified Ephedra and Apricot Kernel and Gypsum and Licorice Decoction combined with western medicine routine treatment. Henan Tradit. Chin. Med. 40, 666-669. doi: 10.16367/ j.issn.1003-5028.2020.05.0167

Sang, F. M., Liu, X. G., and Chen, H. (2014). Efficacy of Haoqinqingdan decoction for damp influenza viral pneumonia and analysis of immune parameters and NF-אB levels. Chin. J. Nosocomiol. 24, 6050-6051, 6054. doi: 10.11816/ cn.ni.2014-134232

Sanjeewa, K. K. A., Jayawardena, T. U., Kim, S. Y., Lee, H. G., Je, J. G., Jee, Y., et al. (2020). Sargassum horneri (Turner) inhibit urban particulate matter-induced inflammation in MH-S lung macrophages via blocking TLRs mediated NF- $\mathrm{KB}$ and MAPK activation. J. Ethnopharmacol. 249, 112363. doi: 10.1016/j.jep.2019.112363

Shen, X., Luo, X., and Li, N. (2012). Molecular mechanism of Lonicera japonica flos against influenza virus H5N1. Shaanxi J. Tradit. Chin. Med. 33, 1247-1248. doi: 10.3969/j.issn.1000-7369.2012.09.086

Sornpet, B., Potha, T., Tragoolpua, Y., and Pringproa, K. (2017). Antiviral activity of five Asian medicinal pant crude extracts against highly pathogenic H5N1 avian influenza virus. Asian Pac. J. Trop. Med. 10, 871-876. doi: 10.1016/ j.apjtm.2017.08.010

Sun, L., Liu, A. L., Wang, Z. Z., Bi, Y. A., Du, G. H., and Xiao, W. (2014). Inhibition of Reduning Injection and its components on neuraminidase in influenza virus. Drugs Clin. 29, 27-31. doi: 10.7501/j.issn.1674-5515.2014.1.006

Sun, L. (2006). Experimental studies of the effects of a Chinese herbal medical compound formula-Kangliyin on an animal model of respiratory coronavirus infection (Guangzhou: Guangzhou University of Chinese Medicine).

Tian, Y. Z., Ding, J., Wang, D. Y., Wu, H. S., Liu, S. L., An, Y. S., et al. (2019). Treatment of 50 cases of influenza A (H1N1) virus pneumonia by adding and subtracting Ergen Qingfei Yin combined with Tanreqing injection. Tradit. Chin. Med. Res. 32, 12-16. doi: 10.3969/j.issn.1001-6910.2019.03.06

Tsou, C. C. (2007). The study of antiviral effect and mechanism of Arctigenin compound on influenza virus in vivo (Guangzhou: Guangzhou University of Chinese Medicine).

Wan, Q. F., Wang, H., Han, X. B., Lin, Y., Yang, Y. H., Gu, L. G., et al. (2014). Baicalin inhibits TLR7/MYD88 signaling pathway activation to suppress lung inflammation in mice infected with influenza A virus. Biomed. Rep. 2, 437-441. doi: $10.3892 / \mathrm{br} .2014 .253$

Wang, S. C., Wang, L., Chen, C., and Liao, H. (2008). Inhibiting effect of medicated serum in Qingfei Oral Liquid on respiratory tract syncytial virus. J. Nanjing TCM. Univ. 24, 25-27. doi: 10.14148/j.issn.1672-0482.2008.01.012

Wang, X. H., Pu, X. Y., Liang, J. P., Shang, R. F., Hua, L. Y., and Liu, Y. (2009). Influence of Hypericum perforatum extract on IFN- $\gamma$, TNF- $\alpha$ of lung tissue of mice infected with influenza A virus. J. Anhui Agric. Sci. 37, 6012-6013. doi: $10.13989 /$ j.cnki.0517-6611.2009.13.139

Wang, S. C., Chen, Z. G., and Xu, S. (2011). Guidelines for TCM diagnosis and treatment of child viral pneumonia. J. Nanjing TCM. Univ. 27, 304-308. doi: 10.14148/j.issn.1672-0482.2011.04.002

Wang, L., Huang, L., Li, Y. B., Gu, L. G., and Wan, Q. F. (2014). Effect of Baicalin on TLR3/TRIF signaling pathway in mice with influenza virus pneumonia. Lishizhen Med. Mater. Med. Res. 25, 2354-2356. doi: 10.3969/j.issn.10080805.2014.10.018

Wang, S. C., Sun, Y. Q., Bian, G. B., Xu, L., Ma, R., Wang, M. Q., et al. (2016). Clinical study on Qingfei Oral Liquid treating 507 cases of phlegm-heat obstructing lung syndrome in children virus pneumonia. World Chin. Med. 11, 1649-1653, 1658. doi: 10.3969/j.issn.1673-7202.2016.09.001

Wang, G., Sun, D. D., Geng, Z. K., Liu, F., Hou, X. W., Li, S. Q., et al. (2019). Research progress on the anti-virus effect of Andrographis paniculate (Birm.f.) Ness. J. Liaoning Univ. Tradit. Chin. Med. 21, 178-181. doi: 10.13194/ j.issn.1673-842x.2019.07.028

Wang, R. Q., Yang, S. J., Xie, C. G., Shen, Q. L., Li, M. Q., Lei, X., et al. (2020). Clinical observation of Qingfeipaidu Decoction in the treatment of COVID-19. Pharm. Clin. Chin. Mater. Med. 36, 13-18. doi: 10.13412/j.cnki.zyyl. 20200303.002

Wang, Y. F., Xu, Q. H., and Duan, M. L. (2020). Regulatory effect of Geniposide on influenza virus-induced lung injury in mice based on the TLR3/ TRIF pathway. Chin. J. Virol. 36, 35-43. doi: 10.13242/j.cnki.bingduxuebao. 003638

Wei, W. J., Wan, H. T., Yu, L., Lu, Y. Y., and He, Y. (2018). Effect and mechanism of Mahuang Tang against influenza A/H1N1 virus in vitro. Chin. J. Chin. Mater. Med. 43, 563-570. doi: 10.19540/j.cnki.cjcmm.20171113.010

Wen, C. C., Shyur, L. F., Jan, J. T., Liang, P. H., Kuo, C. J., Arulselvan, P., et al. (2011). Traditional Chinese medicine herbal extracts of Cibotium barometz, Gentiana scabra, Dioscorea batatas, Cassia tora, and Taxillus chinensis inhibit SARS-CoV replication. J. Tradit. Complement. Med. 1, 41-50. doi: 10.1016/ s2225-4110(16)30055-4

Woolhouse, M. E., Brierley, L., McCaffery, C., and Lycet, t S. (2016). Assessing the epidemic potential of RNA and DNA viruses. Emerg. Infect. Dis. 22, 20372044. doi: $10.3201 /$ eid 2212.160123

World Health Organization (2020). Coronavirus disease (COVID-19) Situation Report-131. (2020-5-30). Available at: https://www.who.int/emergencies/ diseases/novel-coronavirus-2019/situation-reports.

Wu, Q. F., Mi, J. Q., Wu, X. X., and Jiang, Y. Q. (2014). Study of decomposed recipes of Huanglian Xiangru Decoction on anti-influenza virus. Chin. Arch. Tradit. Chin. Med. 32, 2057-2059. doi: 10.13193/j.issn.1673-7717.2014.09.002

Xi, S. Y., and Gong, Y. W. (2017). Essentials of Chinese Materia Medica and Medical Formulas. (San Diego: Elsevier, Academic Press), 35-88. doi: 10.1016/ B978-0-12-812722-3.00002-6

Xi, S. Y., Qian, L. C., Ding, H. P., and Wang, Y. H. (2020). To understand the prevention and treatment of coronavirus disease 2019 based on the theory of traditional Chinese medicine body-state differentiation. Xiamen Univ. Nat. Sci. 59, 304-309. doi: 10.6043/j.issn.0438-0479.202003027

Xia, W. G., An, C. Q., Zheng, C. J., Zhang, J. X., Huang, M., Wang, Y., et al. (2020). Clinical observation on 34 patients with novel coronavirus pneumonia (COVID-19) treated with intergrated traditional Chinese and Western medicine. J. Tradit. Chin. Med. 61, 375-382. doi: 10.13288/j.11-2166/ r.2020.05.002

Xiao, M. Z., Tian, J. X., Zhou, Y. N., Xu, X., Min, X. J., Lv, Y., et al. (2020). Efficacy of Huoxiang Zhengqi dropping pills and Lianhua Qingwen granules in treatment of COVID-19: A randomized controlled trial. Pharmacol. Res. 161, 105126. doi: 10.1016/j.phrs.2020.105126

Xie, Y. H., Shen, Y. J., Jin, S. Y., and Xu, S. J. (2007). Effects of essential oil of Herba schizonepetae on the expression of Myd88 and TRAF6 proteins in mice with influenza virus pneumonia. Pharm. Clin. Chin. Mater. Med. 23, 98-100. doi: 10.3969/j.issn.1001-859X.2007.05.047

Xie, Z. P., Li, H. Y., Yue, X. H., Wang, J. X., Chen, Z. H., Li, X., et al. (2007). Activity against Parainfluenza virus-3 of the active compound (GC3-1-4) from Radix Glycyrrhiza in vitro. Infor. Tradit. Chin. Med. 24, 37-39. doi: 10.19656/ j.cnki.1002-2406.2007.03.020

Xin, S., Cheng, X., Zhu, B., Liao, X., Yang, F., Song, L., et al. (2020). Clinical retrospective study on the efficacy of Qingfei Paidu decoction combined with Western medicine for COVID-19 treatment. Biomed. Pharmacother. 129, 110500. doi: 10.1016/j.biopha.2020.110500

Xu, L. S., Pu, X. Y., Yang, X. H., Guo, A. J., and Yue, L. (2016). The influence of Guan Ye Lian Qiao extract on the immunologic function of influenza virusinfected mice. West. J. Tradit. Chin. Med. 29, 23-27. doi: 10.3969/j.issn.10046852.2016.09.008

Xu, R. H., Li, Y. L., Wang, C. X., Liu, G. X., Liu, C., Zhang, L. L., et al. (2019). Effect of Scutellariae Radix on expression of inflammatory cytokine protein and gene in lung of mice with viral pneumonia caused by influenza virus FM1 infection. Chin. J. Chin. Mater. Med. 44, 5166-5173. doi: 10.19540/j.cnki.cjcmm. 201910.09 .401 
$\mathrm{Xu}, \mathrm{X} . \mathrm{N}$. (2014). The study on the effect of Yinqiaochaigui granule on mouse pneumonia caused by FM1 strain of type A influenza virus (Guangzhou: Guangzhou University of Chinese Medicine).

Yan, Y. Q., Fu, Y. J., Wu, S., Qin, H. Q., Zhen, X., Song, B. M., et al. (2018). Anti Anti-influenza activity of Berberine improves prognosis by reducing viral replication in mice. Phytother. Res. 32, 2560-2567. doi: 10.1002/ptr.6196

Yang, X. Y., Li, J. H., Duan, B. Z., and Huang, L. F. (2017). Antiinfluenza virus activity of Galla Chinensis extracts and UPLC-Q-TOF-MS analysis on its effective Part. Chin. J. Exp. Tradit. Med. Form. 23, 68-72. doi: 10.13422/ j.cnki.syfjx.2017160068

You, H. L., Huang, C. C., Chen, C. J., Chang, C. C., Liao, P. L., and Huang, S. T. (2018). Anti-pandemic influenza A (H1N1) virus potential of catechin and gallic acid. J. Chin. Med. Assoc. 81, 458-468. doi: 10.1016/j.jcma.2017.11.007

Zhang, C. J., and Yu, H. T. (2010). Antagonism of Geniposide on toll like receptor $7 /$ nuclear factor- $\mathrm{\kappa B}$ signaling pathways in cells with influenza A virus infection. Chin. J. Microbiol. Immunol. 30, 749-754. doi: 10.3760/cma.j.issn. 0254-5101.2010.08.014

Zhang, S. J., Chen, Z., Li, G. W., and Wang, B. L. (2013). Effect of the Haoqinqingdan Decoction on damp-heat syndrome in rats with influenza viral pneumonia. Asian Pac. J. Trop. Med. 6, 653-657. doi: 10.1016/S1995-7645 (13)60113-3

Zhang, Y., Liu, X. T., Gu, L. G., Ge, S. J., Wu, J., Qiu, Z. J., et al. (2015). Effects of Shufeng Xuanfei and Jiebiao Qingli Formulas on influenza virus in vitro and vivo. Chin. J. Tradit. Chin. Med. Pharm. 30, 501-503.

Zhang, X. Y., Wang, X. F., and Song, N. (2016). Influence of Qingfeitongluo-pastes and its different disassembled formula on virus load in lung tissue of respiratory syncytial virus pneumonia in rats. Lishizhen Med. Mater. Med. Res. 27, 1307-1309. doi: 10.3969/j.issn.1008-0805.2016.06.010

Zhang, Y., Wu, D. S., Qi, K., Zeng, L. H., Zhang, Y. Y., Li, L., et al. (2018). Mechanism of action of Galla chinensis ethyl acetate extract in alleviating acute lung injury induced by influenza virus in mice. J. Hunan Univ. Chin. Med. 38, 1366-1370. doi: 10.3969/j.issn.1674-070X.2018.12.003

Zhang, R. L., Jiao, Q., Wang, B. G., Feng, L. M., Wang, B., Wang, H. J., et al. (2003). Controlled clinical study on 49 patients of SARS treated by integrative Chinese and western medicine. Chin. J. Integr. Tradit. West. Med. 23, 654-657. doi: 10.7661/CJIM.2003.9.654

Zhang, X. M., Zhang, Y. L., Yang, Z. F., Jin, Y. W., Tan, X. H., Zhang, Y., et al. (2003). Observation on the clinical efficacy of SARS 1,2,3 series formulas in the treatment of SARS. Chin. J. Tradit. Chin. Med. Pharm. 18, 323-326.
Zhang, Y. L., Zhang, X. M., Jin, Y. W., Yang, Z. F., Tan, X. H., Wang, M. Y., et al (2003). Clinical observation of 65 SARS cases treated with a combination of TCM and western-style therapies. J. Beijing Univ. Tradit. Chin. Med. 26, 60-64. doi: 10.3321/j.issn:1006-2157.2003.06.019

Zhao, L., Xiang, K. L., Liu, R. X., Xie, Z. P., Zhang, S. M., and Dai, S. J. (2020). Antiinflammatory and anti-viral labdane diterpenoids from the fruits of Forsythia suspensa. Bioorg. Chem. 98, 103651. doi: 10.1016/j.bioorg.2020.103651

Zhou, M. Q., Yang, L. P., Ma, H. H., Cheng, C. C., Zhang, Y. X., Zhang, J. K., et al. (2020). Network pharmacological study of Qingfei Paidu Decoction intervening on cytokine storm mechanism of COVID-19. J. Hainan Med. Univ. 26, 721-729. doi: 10.13210/j.cnki.jhmu.20200507.003

Zhu, S. Y., Li, X. Y., Wei, Y. L., Yang, P. Y., and Qing, E. D. (2003). Inhibitory effects of three prescriptions of traditional Chinese medicine on SARSassociated coronavirus in vitro. Lett. Biotech. 14, 390-392. doi: 10.3969/ j.issn.1009-0002.2003.05.012

Zhu, L. F., Bao, X. X., Yao, H., and Li, H. B. (2018). Inhibitory effect of Lonicera japonica Thunb. and Houttuynia cordata Thunb. on influenza A virus replication in vitro. Int. J. Lab. Med. 39, 485-486. doi: 10.3969/j.issn.16734130.2018.04.030

Zhu, X. (2008). Experimental study on anti-respiratory syncytial virus (RSV) of water extract of Ephedra sinica in vitro (Changsha: Central South University).

Zhuang, M., Jiang, H., Suzuki, Y., Li, X. G., Xiao, P., Tanaka, T., et al. (2009). Procyanidins and butanol extract of Cinnamomi Cortex inhibit SARS-CoV infection. Antiviral Res. 82, 73-81. doi: 10.1016/j.antiviral.2009.02.001

Zhuang, W., Fan, Z., Chu, Y. Q., Wang, H. Z., Yang, Y., Wu, L., et al. (2020). Chinese patent medicines in the treatment of coronavirus disease 2019 (COVID-19) in China. Front. Pharmacol. 11, 1066. doi: 10.3389/ fphar.2020.01066

Conflict of Interest: The authors declare that the research was conducted in the absence of any commercial or financial relationships that could be construed as a potential conflict of interest.

Copyright (C) $2020 \mathrm{Xi}, \mathrm{Li}$, Yue, Gong, Qian, Liang and Ye. This is an open-access article distributed under the terms of the Creative Commons Attribution License (CC BY). The use, distribution or reproduction in other forums is permitted, provided the original author(s) and the copyright owner(s) are credited and that the original publication in this journal is cited, in accordance with accepted academic practice. No use, distribution or reproduction is permitted which does not comply with these terms. 